\title{
REALLOCATION, COMPETITION and PRODUCTIVITY: EVIDENCE FROM A FINANCIAL LIBERALIZATION EPISODE*
}

\author{
LILIANA VARELA
}

April 2017

\begin{abstract}
This paper studies the impact of distortions in the access to international capital markets on competition and productivity. I show that a reduction in these distortions leads to an increase in aggregate productivity through two different channels. First, firms that were previously credit constrained respond to better financing terms by increasing their investment in technology, a reallocation effect. Second, non-constrained firms also expand their investment in technology because of increased competition, a pro-competitive effect. I provide evidence for these two channels using firm-level census data from the deregulation of international financial flows in Hungary.
\end{abstract}

Keywords: TFP, firm-level distortions, market competition, financial liberalization.

JEL: F36, F43, O47.

\footnotetext{
* Department of Economics, University of Houston, and Department of Economics, University of Warwick (email: lvvarela@uh.edu). I thank the editor and three anonymous referees for helpful remarks and suggestions. I am grateful to Vasco Carvalho and Romain Rancière for their guidance in this project, and to Kei-Mu Yi, Laura Alfaro, Paco Buera, Jaume Ventura, Paula Bustos, Alberto Martin, Aimee Chin, Dietrich Vollrath, Sebnem Kalemli-Ozcan, Bent Sorensen, Chinhui Juhn, Philippe Aghion, Alessandra Bonfiglioli, Jean Imbs, and Gilles Saint-Paul, as well as participants at several seminars and conferences for helpful comments and suggestions. I am grateful to the Research and Statistics departments of the National Bank of Hungary for sharing the database for this project.
} 


\section{INTRODUCTION}

International financial integration has been traditionally viewed as an engine of growth leading to a more efficient allocation of capital across countries and accelerating the convergence of developing economies. Yet financial crises in emerging markets during the nineties challenged this view and led to a reassessment of the benefits of capital account liberalization. Scholars and policy makers started to consider the possibility of, and even advocate, capital controls to reduce the extent of international financial integration. This paper assesses the impact of financial liberalization on firms' access to external finance and its implications for market competition and economic growth.

This paper shows that capital controls can create asymmetric access to capital markets across firms, which distorts competition and economy-wide incentives to innovate. I start by showing theoretically that, provided financial development is sufficiently high, financial liberalization leads to aggregate productivity growth through two different channels. First, it improves financing terms and encourages firms that were previously credit constrained to invest in technology, a reallocation effect. Second, it tightens product market competition and induces non-constrained firms to do the same, a pro-competitive effect. Next, I empirically test these two channels using firm-level census data from the period covering the deregulation of international financial flows in Hungary. This reform revoked capital controls that had imposed asymmetric access to international borrowing across firms. This pre-reform asymmetry between discriminated firms -those that, by law, were previously shut out of international credit markets- and non-discriminated firms allows me to identify the effects of financial liberalization across firms. The empirical results support the view that financial liberalization can lead to a reduction in asymmetric access to external finance across firms, which deepens competition and promotes a broad-based increase in firms' investment in technology. This paper provides, for the first time, firm-level evidence for the micro-mechanisms underpinning the substantial increases in aggregate productivity that follow financial liberalization episodes, a robust correlation previously documented in a large cross-country literature.

To guide my empirical work, I develop a small open economy model in which capital controls create asymmetric access to capital markets across firms that affects the tightness of competition and investment in technology. The model shows that the impact of financial liberalization on capital-scarce economies depends on the local level of financial development. If financial development is sufficiently high, a reduction in capital controls leads to capital inflows and a decrease in the domestic interest rate that reduces asymmetric access to external finance across firms. Financial liberalization promotes aggregate productivity growth through two channels. Discriminated firms innovate more because the reduction in the domestic interest rate raises their post-innovation profits. Non-discriminated firms also innovate more because increased competition raises their incremental profits from innovating. In this case, financial liberalization is associated with capital inflows, deeper competition, and aggregate productivity growth. If financial development is low, however, a reduction in capital controls leads to capital outflows and to an increase in asymmetric access to capital markets across firms, which undermines competition and economy-wide investment in technology. 
I next use the deregulation of international financial flows in Hungary in 2001 to test the model's qualitative implications. A key feature of the period before the liberalization is that capital controls had distorted the access to international borrowing across firms. This feature allows me to identify the effect of the reform within Hungary. In particular, capital controls restricted domestic firms to borrow locally in a tight credit market while allowing foreign firms to raise funds abroad and, thus, circumvent the low credit in the Hungarian financial system. In 2001, all capital controls were lifted and, with them, the ban on domestic firms' international borrowing. In my empirical analysis, I exploit this asymmetric access to international funds between domestic and foreign firms prior to the liberalization as a first source of cross-sectional variation. I complement this analysis by adding a second source of cross-sectional variation -differential needs for external finance at the sector level- and test whether the liberalization affected firms differentially as a function of their sectoral exposure to the reform.

The firm-level census data that I analyze (APEH, a database from the Statistical Department of the National Bank of Hungary) provides information on firms' balance sheets reported to tax authorities for all manufacturing firms during the period 1992-2008. This extensive database allows me to build comprehensive firm-level measures of productivity, capital, and use of external finance over a long panel. It constitutes an advance over previous studies in the financial liberalization literature that focused only on small samples of large and publicly listed firms. In addition, I complement my analysis with the Business Environment and Enterprise Performance Surveys (BEEPS) of the World Bank and the European Bank for Reconstruction and Development, which report direct information on firms' R\&D, innovation activities, and financing terms.

In my empirical analysis, I first document that capital controls in Hungary were associated with a low level of credit as well as worse financing conditions and lower leverage for domestic firms, even after controlling for firm-observable characteristics. The liberalization of capital controls in 2001 led to large capital inflows and to an expansion in the local credit supply that substantially improved financing terms for these firms. By 2004, the difference in the interest rate paid by domestic and foreign firms had fallen five-fold, and the difference in the required collateral had dropped four-fold. This improvement in financing terms was associated with a $23 \%$ increase in domestic firms' leverage and a reallocation of credit towards these firms, whose share of aggregate credit increased by 17 percentage points.

I then assess whether this reduction in capital market distortions is consistent with reallocation towards domestic firms. In line with this first channel, I demonstrate that, while prior to the financial liberalization, domestic and foreign firms' growth rates were not statistically different, following the reform, domestic firms started growing much faster. In particular, I find that domestic firms differentially increase their capital intensity (25\%), labor productivity (5\%), revenue TFP (RTFP) (3\%), and probability of conducting R\&D and innovation activities (9 and 12 percentage points). ${ }^{1}$ In line with the easing of financing terms, this expansion is greater in sectors where

\footnotetext{
${ }^{1}$ It is important to differentiate revenue TFP from physical TFP. Unfortunately, given the lack of information on firms' prices, I am only able to measure RTFP. See also Foster, Haltiwanger, and Syverson (2008).
} 
domestic firms had greater needs for external finance. Notably, domestic firms differentially increase their leverage as a function of sectoral financial needs.

Additionally, my results point to the second, pro-competitive, channel. First, foreign firms' markups decreased by $3 \%$ relative to domestic firms. Second, this decline is larger in sectors that have greater needs for external finance, which are sectors where competition was initially more distorted, as domestic firms were more affected by the asymmetric access to capital markets. I find that one standard deviation increase in the index of financial dependence decreases foreign firms' markups by $6 \%$. Third, I also show that foreign firms increased their labor productivity, RTFP, and skill intensity as a function of sector dependence on external finance. Importantly, they did not increase their capital intensity nor their leverage. This suggests that these firms were not initially credit constrained but were responding to the tighter competition of domestic firms in those sectors. Finally, at the industry level, I find that the greater expansion of domestic firms led to reductions in industry concentration and in productivity and markup dispersion within sectors.

The expansion in firms' productivity resulted in an increase in aggregate productivity growth. Notably, the source of this growth completely reversed following the liberalization. Prior to the reform, within-firm productivity explained only $17 \%$ of aggregate productivity growth, but after the reform, within-firm productivity explained $82 \%$ of aggregate productivity growth. This upsurge in the within-firm component is consistent with the mechanism proposed in this paper, arguing for the pro-competitive forces of financial liberalization that led all firms to increase their productivity.

The empirical identification of the effect of the financial liberalization is based on the asymmetric access to international borrowing between domestic and foreign firms prior to the reform. To test that the observed effects correspond to the liberalization and not something else, I conduct a full set of robustness tests. First, I estimate the effects by year and show that the differential response of domestic and foreign firms coincides with the timing of the reform, as the estimated coefficients do not vary prior to the liberalization, while they monotonically change following it. Second, I demonstrate that the results are not driven by sector-specific trends, as they are robust to including four-digit sector pre-reform growth trends and sector-year fixed effects. Third, the general context around the liberalization and its timing minimizes reverse causality concerns, as it was part of a general program of fourteen transition economies to join the European Union (EU). Importantly, by 2001, the deregulation of capital controls in Hungary was the only missing requirement to join the EU. The Hungarian economy was already deeply integrated with the EU, and trade and foreign direct investment (FDI) flows remained constant in the years prior to and following the liberalization. Notably, I do not find any differential pattern of growth between exporter and nonexporter firms. Additionally, I also show that other transition economies undergoing the same process of joining the EU but with already deregulated financial accounts did not witness the same pattern of capital inflows observed in Hungary.

This paper adds to a long literature on the relationship between international financial integration and economic growth in developing countries (Gertler and Rogoff 1990; Gourinchas and Jeanne 2006; Mendoza, Quadrini, and Rios-Rull 2009; and Levchenko, Ranciere, and Thoenig 2009, 
among others). It illustrates that, in capital-scarce economies, the impact of financial liberalization depends on the local level of financial development. If financial development is sufficiently high, capital openness induces inflows as well as higher innovation, market competition, and economic growth. If financial development is low, however, financial liberalization leads to outflows and to lower investment and growth. This paper also relates to cross-country studies associating financial liberalization with increases in aggregate productivity. ${ }^{2}$ Bonfiglioli (2008), Bekaert, Harvey, and Lundblad (2011), and Chari, Henry, and Sasson (2012) find a positive impact of financial liberalization on aggregate productivity over the five years following a reform. This paper proposes a mechanism that can explain the increase in aggregate productivity found in these cross-country studies and uses firm-level census data from a particular reform to test it. This paper also informs the debate on the impact of capital controls in developing economies and shows that these controls can create asymmetric access to capital markets across firms, which undermines competition, investment in technology, and economic growth. ${ }^{3}$

This paper is also related to the misallocation literature emphasizing how firm-level distortions can lower aggregate productivity (Restuccia and Rogerson 2008; Hsieh and Klenow 2009; Peters 2013; and Restuccia and Rogerson 2013). This paper is closest to Peters (2013), who shows that these distortions can affect both the static allocation of resources and firms' dynamic innovation incentives. My paper departs from Peters' (2013) in that I identify in the data a particular policy distortion and study how this distortion affects competition and all firms' innovation incentives. Focusing on access to capital markets, Gopinath, Kalemli-Ozcan, Karabarbounis, and VillegasSanchez (2017) report large productivity losses from misallocation due to financial frictions. Additionally, Midrigan and Xu (2014) show that financial frictions can preclude credit-constrained firms from adopting more efficient technologies. This paper shows that the effect of financial frictions on productivity can be amplified through pro-competitive forces, which undermine both constrained and non-constrained firms' incentives to invest in technology. This view is complementary to that developed by Edmond, Midrigan, and Xu (2015), who uncovered large pro-competitive effects from a removal of another distortion in a trade liberalization reform.

The remainder of the paper is structured as follows. In Section 2, I present the model that guides the empirical work. Section 3 describes the liberalization of international financial flows in Hungary. Section 4 presents the data. In Section 5, I discuss the identification strategy and test the model's qualitative implications. Section 6 concludes.

\footnotetext{
${ }^{2}$ In a similar vein, several studies show a positive relationship between financial deepening and productivity enhancements. In particular, they find that countries with more developed financial systems enjoy higher rates of productivity growth. See, for example, King and Levine (1993a); King and Levine (1993b); Benhabib and Spiegel (2000); and Beck, Levine, and Loayza (2000).

${ }^{3}$ See, for example, Forbes (2007a); Forbes (2007b); Desai, Foley, and Hines (2006); Devereux and Yetman (2014); and Schmitt-Grohé and Uribe (2016), who discuss the impact of capital controls on countries.
} 


\section{MODEL}

This section develops a small open economy model to study the impact of distortions in the access to international capital markets on competition and aggregate productivity. The model has three main ingredients. First, there are domestic and foreign firms that engage in R\&D and produce in oligopolistic markets. Second, there is a local banking sector that has a low level of financial development and affects the direction of capital flows upon the financial liberalization. Third, there are capital controls that prevent local firms from accessing international funds. I employ the model to study the impact of financial liberalization on competition and firms' investment in technology. Focusing on the case in which the liberalization leads to capital inflows, I derive qualitative implications to test using data in Section 5. These implications are derived analytically in partial equilibrium and are illustrated in general equilibrium using a numerical exercise in Appendix B.4.

\subsection{Environment}

Consider a small economy populated by an infinite sequence of overlapping generations, each of which lives for two periods. The economy is composed of firms, workers, and banks. This overlapping generations setting simplifies households' saving decisions and focuses on the impact of capital controls on market competition and on firms' incentives to invest in technology. A final good is an aggregate of a continuum of intermediate varieties. In each intermediate variety, domestic firms compete with foreign producers. Domestic and foreign firms differ in their initial productivity and access to capital markets. Labor is internationally immobile.

\section{i) Firms' Production and Innovation}

-Production. Intermediate firms operate with a Cobb-Douglas function: $f(q, k, l)=q k^{\alpha} l^{1-\alpha}$, where $q, k$, and $l$ are productivity, capital, and labor, and $\alpha \in(0,1)$. Capital fully depreciates after production. Within each intermediate variety, a foreign and a home firm compete à la Bertrand. In equilibrium, only the firm with the lowest marginal cost is active in the variety. To deter entry, this firm resorts to limiting pricing and sets its price equal to the marginal cost of its closest rival. ${ }^{4}$

-Innovation and Technology. Intermediate firms are heterogeneous in productivity and conduct innovation activities in the first period to try to obtain a frontier technology. The innovation process is stochastic and depends on the firm's innovation efforts $x_{s}$, where $s=\{H, F\}$ denotes home and foreign firms. If the firm gets a frontier technology in the variety, it produces in $t+1$; otherwise it exits the market. For expositional simplicity, I assume that, in each variety, foreign firms enjoy a higher initial productivity level, but home firms can leapfrog the technology frontier. ${ }^{5}$ Hence, in each

\footnotetext{
${ }^{4}$ The pro-competitive effects of financial liberalization are also present in other oligopolistic frameworks, as in Devereux and Lee (2001), Atkeson and Burstein (2008) and Edmond, Midrigan, and Xu (2015), in which firms compete by quantities in a Cournot setting. See Appendix B.6.

${ }^{5}$ The assumption that foreign firms are more productive than home firms is consistent with the empirical pattern observed in Hungary prior to the reform, as shown in Section 5. Moreover, this is a common trait of developing
} 
intermediate variety, innovations can originate from two sources: either the foreign firm improves the existing technology, or the home firm innovates and obtains a new state-of-the-art technology. ${ }^{6}$ Let the initial productivity of firm $s$ in variety $j$ be: $q_{s j} \equiv \lambda^{n_{s j}}$, where $\lambda>1$ and $n_{s j}$ is the firm's technology level, which evolves as in a quality ladder. Express the initial productivity difference between foreign and home firms in variety $j$ as a function of the technological gap between them: $\Delta_{j} \equiv n_{F j}-n_{H j}$. Finally, consider an R\&D technology such that if a firm aims for an innovation effort of $x_{s j}$, it needs to undertake $\Gamma$ units of labor:

$$
\Gamma\left(x_{F j t}, \Delta_{j}\right)=\lambda^{-\Delta_{j}} \frac{1}{\phi} \frac{x_{F j t}^{2}}{2} \text { and } \Gamma\left(x_{H j t}\right)=\frac{1}{\phi} \frac{x_{H j t}^{2}}{2}
$$

where $\phi$ denotes the efficiency of the innovation technology, and $x_{s j t} \in(0,1)$ are firms' endogenous innovation probabilities. As in Klette and Kortum (2004), Atkeson and Burstein (2010), and Peters (2013), I let more efficient firms have lower innovation costs to account for the empirical finding that innovation efforts are constant for large firms. As in Peters (2013), I assume that the innovation of foreign firms is easier when their technological advantage is greater, i.e. $\lambda^{-\Delta}$. This assumption simplifies the exposition and does not affect the model's implications (as shown in Appendix B.7). Firms take the innovation efforts of other agents and factor prices as given.

The final good aggregates a continuum of measure one of $j$ intermediate varieties, employing a Cobb-Douglas production function $Y_{t+1}=\exp \left(\int_{0}^{1} \log \left(y_{j t+1}\right) d j\right)$. Given this final good production, the optimal demand for each intermediate variety $j$ is $y_{j t+1}=\frac{Y_{t+1}}{p_{j t+1}}$.

The timeline is as follows. Workers supply labor inelastically for a wage during their youth in $t$ and consume during their old age in $t+1$. In the first period, intermediate firms make two decisions: first, they choose their optimal innovation efforts; next, once the innovation process is realized, they decide whether to produce in the second period. To produce, firms need to invest in physical capital in $t$. Banks collect savings from households to lend to firms. ${ }^{7}$ Active firms produce.

TIMING

\begin{tabular}{|c|c|}
\hline$t$ & $t+1$ \\
\hline & Young workers supply labor (...) \\
\hline Young workers supply labor (innovation \& production) & $\longrightarrow$ Old workers consume. \\
\hline New firms innovate: & \\
\hline $\begin{array}{l}\text {-if successful, invest in capital } \\
\text {-otherwise, exit }\end{array}$ & $\longrightarrow$ Active firms produce. \\
\hline
\end{tabular}

economies, as reported by Gorodnichenko and Schnitzer (2013). Finally, note that a home firm would not invest simply to catch-up to its rival's technology, as it would earn zero profits (see also Grossman and Helpman 1991).

${ }^{6} \mathrm{I}$ assume that the probability of two firms innovating at the same time is zero, to be consistent with standard models of innovation (Grossman and Helpman 1991; Aghion and Howitt 2009; among others).

${ }^{7}$ For simplicity, I let firms borrow from banks once they learn about the result of the innovation process and, hence, there is no uncertainty in the debt contract. As standard in innovation models, this assumption implies that workers are able to insure against the innovation risk (see Acemoglu 2009; Aghion and Howitt 1992; Peters 2013). 


\section{ii) Banking Sector and Capital Controls}

Consider a perfectly competitive banking sector in which risk-neutral banks act as intermediaries that collect savings from young workers to lend to local firms. Banks face an intermediation cost $\mu$ per unit of amount lent that depends on the level of financial development in the country, $\mu>0$. In equilibrium, the domestic lending $\left(R_{t+1}^{L}\right)$ and deposit $\left(R_{t+1}^{D}\right)$ interest rates satisfy

$$
R_{t+1}^{L}=R_{t+1}^{D}+\mu
$$

Capital controls on domestic agents allow only local banks to intermediate foreign funds, but they incur a cost. In particular, banks need to pay a tax $\tilde{\tau}$ per unit of foreign borrowing or lending, which is then redistributed lump-sum to local households. Importantly, this tax level determines whether banks have incentives to intermediate foreign funds and, accordingly, whether the economy is open or closed to international financial flows.

To determine the direction of capital flows upon the liberalization is necessary to solve for the equilibrium interest rate in the closed economy. Accordingly, I start by presenting an economy in which the tax rate on foreign transactions is high enough such that banks do not intermediate foreign funds and international financial flows are shut down (Sections 2.2 and 2.3). Next, I turn to study the effects of a reduction in capital controls (Section 2.4). I normalize the intermediation cost of the world to zero and denote the foreign interest rate as $R_{t+1}^{*}$. Focusing on a capital-scarce economy, I let the domestic lending rate -to be determined below- be higher than the foreign rate: $R_{t+1}^{L}>R_{t+1}^{*}$.

\subsection{Firms' Optimal Behavior and Aggregate Productivity Growth}

Firms' optimal strategies are solved by backward induction. I focus on the main results and present the derivations in Appendix B.

-Production and Price Setting. In this Bertrand setting, only the firm with the lowest marginal cost in each variety is active in equilibrium. The marginal cost of the active firm in variety $j$

is $M C_{s j t+1}=\frac{1}{q_{s j t+1}}\left(\frac{R_{t+1}^{s^{\prime}}}{\alpha}\right)^{\alpha}\left(\frac{w_{t+1}}{1-\alpha}\right)^{1-\alpha}$, where $R^{s^{\prime}}$ is either the local lending rate for home firms $\left(R^{L}\right)$ or the world rate $\left(R^{*}\right)$ for foreign firms. Higher financing terms imply higher marginal costs. After minimizing its production costs and setting its price, the active firm's profit from production activities is $\Pi_{s j t+1}^{p}=\left(1-\xi_{s j t+1}^{-1}\right) Y_{t+1}$, where $\xi_{s j t+1}$ denotes its markup. This expression shows that a firm's profit is proportional to its markup, which is the only firm-specific variable in the expression. In equilibrium, the active firm's markup is equal to the intermediate good's price over the marginal cost, where the price is set to the marginal cost of the firm's closest competitor, and its marginal cost depends on the result of the innovation process and financing costs. I present separately the cases in which either the foreign or the home firm is active in equilibrium. 
If the foreign firm in variety $j$ is active, its markup will be either

$$
\xi_{F j t+1}^{p o s t} \equiv \frac{p_{j t+1}}{M C_{F j t+1}^{p o s t}}=\tau_{t+1} \lambda^{\Delta_{j}+1} \quad \text { or } \quad \xi_{F j t+1}^{p r e} \equiv \frac{p_{j t+1}}{M C_{F j t+1}^{p r e}}=\tau_{t+1} \lambda^{\Delta_{j}}
$$

where post and pre denote whether it succeeds in improving its technology or maintains its initial productivity level. Equation (2) shows that the foreign firm's markup has two components. First, as in quality ladder models, the leader's markup increases with the technology gap between the leader and its closest market rival $\left(\Delta_{j}\right)$ because the productivity advantage allows setting higher prices. Second, the new feature of the model is that the foreign firm's markup is distorted by $\tau_{t+1}$, where $\tau_{t+1} \equiv\left(R_{t+1}^{L} / R_{t+1}^{*}\right)^{\alpha}>1$ and represents the difference in borrowing costs between home and foreign firms. Therefore, besides any technological advantage that foreign firms might enjoy, they can obtain higher markups stemming from their preferential access to capital markets. That is, a higher local lending rate implies high marginal costs for home firms, which undermines their competitive pressure and allows foreign firms to set higher prices.

If instead the home firm in variety $j$ is active, its markup will be

$$
\xi_{H j t+1}^{p o s t} \equiv \frac{p_{j t+1}}{M C_{H j t+1}^{p o s t}}=\frac{1}{\tau_{t+1}} \lambda .
$$

Similar to foreign firms' markups, equation (3) shows that the home firm's markup depends on the technology advantage and the asymmetric access to international capital markets. However, unlike the foreign firm, the home firm's markup is reduced by the differential access to finance, $\tau_{t+1}$. The reason is that, even if the home firm manages to obtain a frontier technology and the lowest marginal cost, it still faces higher borrowing costs than its foreign rival. If the home firm does not succeed in obtaining a frontier technology, it will continue to have a higher marginal cost than its foreign rival and will remain out of the market. I now turn to study how this distortion in firms' profits affects their incentives to invest in technology.

-Innovation Activities. In the first period, firms choose their optimal innovation efforts so as to maximize their expected profits net of the innovation costs. After maximizing their total profits, their optimal innovation intensities, $x_{F t}$ and $x_{H t}$, become

$$
x_{F t}=\frac{\phi}{\tau_{t+1}} \frac{\left(1-\lambda^{-1}\right)}{w_{t}} \frac{Y_{t+1}}{R_{t+1}^{*}} \quad \text { and } \quad x_{H t}=\frac{\phi}{\tau_{t+1}^{1 / \alpha}} \frac{\left(1-\tau_{t+1} \lambda^{-1}\right)}{w_{t}} \frac{Y_{t+1}}{R_{t+1}^{*}} .
$$

As in quality ladder models, firms' optimal innovation efforts depend on the market size (Y), the efficiency of the innovation technology $(\phi)$, the increment in technology $(\lambda)$, and the innovation cost in labor units $(w)$. The new feature of the model is that all firms' optimal innovation efforts also depend on the distortion in the access to international capital markets. Critically, home and foreign firms' efforts are reduced by $\tau_{t+1}$. Two forces lead to this result. Regarding home firms, their higher borrowing costs reduce their post-innovation profits and, hence, their innovation incentives. 
Concerning foreign firms, their innovation efforts are reduced because -when they are the market leaders- they face weak competition and enjoy greater monopolistic power to set prices. Higher prices lower their production levels and, hence, their innovation incentives aiming to reduce the production costs. In this way, differences in borrowing costs affect all firms' markups and, hence, their profits and optimal innovation efforts.

-Aggregate Productivity Growth. In each intermediate variety, the expected productivity increase is given by $\log (\lambda)\left(x_{H t}+x_{F t}\right)$, as each innovation raises productivity by a factor of $\log (\lambda)$, and domestic and foreign firms innovate with a probability $x_{H t}$ and $x_{F t}$. Under the law of large numbers, a continuum of varieties ensures that aggregate productivity growth is given by

$$
g_{Q t+1}=\log (\lambda)\left(x_{F t}+x_{H t}\right) .
$$

Equation (5) shows that distortions in the access to international capital markets significantly reduce aggregate productivity growth, as they decrease home and foreign firms' innovation efforts.

\subsection{Equilibrium}

An equilibrium is represented by the sequence $\left\{x_{s t}, p_{s j t+1}, y_{s j t+1}, w_{t+1}, R_{t+1}^{L}\right\}_{t=0}^{\infty}$ such that: banks have zero profits and equation (1) is satisfied; active firms in each variety set the price equal to the marginal cost of the closest competitor, and the intermediate optimal demand for each variety $\left(y_{j t+1}\right)$ is satisfied; firms' innovation intensities are given by equation (4), such that $x_{H t}$ and $x_{F t}$ maximize expected profits taking aggregate output, wages, interest rates, and the innovation efforts of other firms as given; the economy growth rate is $g_{Y t+1}=\frac{1}{1-\alpha} g_{Q t+1}$, where $g_{Q t+1}$ is given by (5); labor and capital markets clear; aggregate consumption is the sum of old workers' consumption, and aggregate output is given by $Y_{t+1} \cdot{ }^{8}$

Labor market clearing implies that all workers are employed in either production $\left(L^{P}\right)$ or innovation activities $\left(L^{I}\right)$, i.e. $L_{t+1} \equiv 1=L_{t+1}^{I}+L_{t+1}^{p}$. In this closed economy, capital market clearing implies that home firms' investment equals the local savings of young workers, and the domestic lending and deposit interest rates are given by

$$
R_{t+1}^{D}=R_{t+1}^{L}-\mu=\alpha \frac{Y_{t+1}}{K_{t+1}^{H}} \Lambda_{t+1}^{H}-\mu
$$

where $K_{t+1}^{H}$ and $\Lambda_{t+1}^{H}$ are the aggregate capital demand and markups of active home firms. Equation (6) shows that the domestic deposit rate depends on two components: the domestic capital stock and the local level of financial development. Importantly, they operate in opposite directions. First, as in a standard small economy model, the more capital scarce is the economy, the higher

\footnotetext{
${ }^{8}$ See Appendix B.1 for derivations.
} 
is the lending rate and, hence, the deposit interest rate. Second, the lower is the level of financial development (higher $\mu$ ), the lower is the deposit rate. Hence, the equilibrium level of the deposit interest rate in the closed economy depends on which of the two components prevails. The economy's budget constraint is given by $C_{t+1}+I_{t+1}^{H}=w_{t+1} L_{t+1}^{p}+R_{t+1}^{D} K_{t+1}^{H}+\Pi_{t+1}^{H}$, where domestic consumption and home investment equal the wages in production activities, payments to home capital, and net profits of active domestic firms. Note that foreign firms invest capital until their return is equal to the world interest rate. The balance of payment implies that the current and capital account sum to zero and that foreign firms' net profits and capital repayment equal their investment: $-\left[\Pi_{t+1}^{F}+R_{t+1}^{*} K_{t+1}^{F}\right]+I_{t+1}^{F}=0$.

\subsection{Financial Liberalization}

I turn to study how a reduction in capital controls affects capital flows, competition, and investment in technology. I first introduce how these controls affect banks' optimal behavior and, through them, the direction of capital flows upon the financial liberalization (Section 2.4.1). Next, I present the case in which financial liberalization leads to capital inflows and derive the qualitative implications of a reduction in capital controls that guide the empirical analysis (Section 2.4.2). ${ }^{9}$

\subsubsection{Banks and the Direction of Capital Flows}

Under capital controls, banks have two financing choices: they can either use local savings and pay the deposit rate $R_{t+1}^{D}$ or borrow foreign savings and pay the world rate plus the per unit $\operatorname{tax} R_{t+1}^{*}+\tilde{\tau}$. Similarly, banks have two lending options: they can either lend to home firms for a net return of $R_{t+1}^{L}-\mu$ or pay the tax and lend internationally for a return $R_{t+1}^{*}-\tilde{\tau}$. I have assumed earlier that $\tilde{\tau}$ was prohibitively high such that banks did not intermediate foreign funds (i.e. $R_{t+1}^{D}<R_{t+1}^{*}+\tilde{\tau}$, and $R_{t+1}^{L}-\mu>R_{t+1}^{*}-\tilde{\tau}$ ). I present below how a reduction in capital controls affects banks' financing and lending activities and, hence, the direction of capital flows upon the liberalization.

Financial liberalization implies a reduction in the tax on foreign transactions to $\hat{\tau}$. In this capital-scarce economy, the direction of capital flows upon the liberalization depends on the country's level of financial development. This economy faces two different cases. First, if the local level of financial development is sufficiently high (low $\mu$ ), the closed-economy domestic deposit rate is greater than the foreign rate plus the new tax on foreign transactions $\left(R_{t+1}^{D}>R_{t+1}^{*}+\hat{\tau}\right)$, and banks find it less costly to finance themselves using foreign funds. Furthermore, since the return from lending abroad is lower than the net local lending rate, banks only lend locally. ${ }^{10}$ This is the case

\footnotetext{
${ }^{9}$ Section B.5 develops the case in which financial liberalization leads to capital outflows.

${ }^{10}$ To see this, consider that $R_{t+1}^{D}>R_{t+1}^{*}+\hat{\tau}$ implies that $R_{t+1}^{L}-\mu>R_{t+1}^{*}+\hat{\tau}$, which is greater than $R_{t+1}^{*}-\hat{\tau}$, i.e. the net interest rate that banks would obtain from lending abroad. Banks' optimal choices are derived formally in Appendix B.2.
} 
in which the economy receives capital inflows. Second, if instead the level of financial development is low (high $\mu$ ), the net interest rate that banks would receive from lending locally is lower than the net return from lending abroad $\left(R_{t+1}^{L}-\mu<R_{t+1}^{*}-\hat{\tau}\right)$, and banks prefer to lend to foreign agents. Additionally, banks finance themselves by employing local savings only because the local deposit rate is lower than the cost of employing foreign savings. ${ }^{11}$ This is the case in which the economy sees capital outflows. The next section discusses the implications of a reduction in capital controls leading to capital inflows on market competition and investment in technology for an economy subject to capital controls with $\hat{\tau}$.

\subsubsection{Qualitative Predictions}

Capital inflows reduce the domestic deposit rate until it is equal to the foreign interest rate plus the new tax level $(\hat{\tau})$, and banks become indifferent between using local or foreign savings. In the new equilibrium, the domestic deposit and lending rates, $\hat{R}_{t+1}^{D}$ and $\hat{R}_{t+1}^{L}$, are given by

$$
\hat{R}_{t+1}^{D}=R_{t+1}^{*}+\hat{\tau} \quad \text { and } \quad \hat{R}_{t+1}^{L}=R_{t+1}^{*}+\hat{\tau}+\mu
$$

The domestic deposit and lending rates become exogenously determined and lower than in the closed economy. Crucially, this decrease in the local lending rate reduces the asymmetric access to external finance between foreign and home firms. ${ }^{12}$

To analyze the effects of financial liberalization on competition and productivity, I conduct comparative statics exercises with respect to $\tau$ and derive five qualitative implications of the effect of a reduction in capital controls. These propositions, discussed formally in Appendix B.3, are derived analytically in a partial equilibrium setting where aggregate output and wages are held constant, and are confirmed in general equilibrium using a numerical illustration in Appendix B.4. ${ }^{13}$

-Proposition 1: Innovation intensities. A reduction in the asymmetric access to international borrowing $(\tau)$ encourages home and foreign firms to increase their innovation intensities ( $x_{H t}$ and $\left.x_{F t}\right)$. Notably, the innovation efforts of home firms increase relatively more:

$$
\frac{\partial x_{F t}}{\partial \tau_{t+1}}<0, \quad \frac{\partial x_{H t}}{\partial \tau_{t+1}}<0 \quad \text { and } \quad\left|\frac{\partial x_{F t}}{\partial \tau_{t+1}}\right|<\left|\frac{\partial x_{H t}}{\partial \tau_{t+1}}\right| .
$$

Proposition 1 states that financial liberalization leading to capital inflows encourages home and

\footnotetext{
${ }^{11}$ Note that as $R_{t+1}^{D}<R_{t+1}^{*}-\hat{\tau}, R_{t+1}^{D}<R_{t+1}^{*}+\hat{\tau}$, implying that the local deposit rate is lower than the cost of raising foreign funds.

${ }^{12}$ Note that, given a change in capital controls, the lower is the level of financial development, the lower is the decrease in the domestic lending interest rate and the increase in capital inflows. This is in line with cross-country studies showing that the impact of financial liberalization is larger in countries with a higher level of financial development, as in Bekaert, Harvey, and Lundblad (2011); and Kose, Prasad, Rogoff, and Wei (2008).

${ }^{13}$ In these propositions, I assume an additional technical restriction on $\lambda<2$. This parameter relates to the frequency of the innovations and is usually parametrized between 1.05 and 1.25 (see Stokey 1995; Bloom, Schankerman, and Van Reenen 2013; and Acemoglu and Akcigit 2011, among others).
} 
foreign firms to increase their innovation efforts. Home firms invest more in technology because the liberalization reduces their financing costs, increasing their post-innovation profits. Foreign firms invest more in technology because the benefit from innovating increases. That is, the liberalization narrows the gap between firms' marginal costs, deepening competition and inducing foreign firms to increase innovation efforts to escape competition. ${ }^{14}$ Importantly, the innovation efforts increase more for home firms. As foreign firms are more productive than home firms, then -in the average intermediate variety- the former are the incumbents and the latter are the entrants. Since the distortion has a greater effect on the innovation incentives of the entrant-home firms relative to that which undermines the foreign market leader (Arrow's replacement effect), the liberalization has a relative greater impact on the home firms' innovation efforts.

-Proposition 2: Leverage. A reduction in $\tau$ raises home firms' expected debt-to-sales ratio $\left((d / y)_{H j t+1}^{e}\right)$ :

$$
\frac{\partial(d / y)_{H j t+1}^{e}}{\partial \tau_{t+1}}<0
$$

Financial liberalization lowers home firms' financing costs, encouraging their investment and leverage.

-Proposition 3: Markups. A decrease in $\tau$ reduces foreign firms' expected markups $\left(\xi_{F j+1}^{e}{ }\right)$ :

$$
\frac{\partial \xi_{F j t+1}^{e}}{\partial \tau_{t+1}}>0
$$

Foreign firms' markups originate from two sources: the difference in the borrowing costs and the technological gap between the foreign firms and their local competitors. Both of these drop following the reduction in capital controls. First, the improvement in financing terms deepens the competitive pressure of home firms, undermining foreign firms' ability to set higher prices and obtain higher markups. Second, the greater innovation efforts of home firms reduce the technology gap between the home firms and their foreign rivals.

-Proposition 4: Productivity gap. Reductions in the asymmetric access to capital markets $(\tau)$ decrease the expected productivity gap between home and foreign firms $\left(\Delta_{t+1}^{e}\right)$. In particular, this drop is greater in varieties where foreign firms were technologically far ahead of their local competitors:

$$
\frac{\partial \Delta_{t+1}^{e}}{\partial \tau_{t+1}}>0 \quad \text { and } \quad \frac{\partial \Delta_{t+1}^{e}}{\partial \tau_{t+1} \partial \Delta_{t+1}}>0
$$

As home firms' innovation efforts increase relatively more, they are more likely to overtake their

\footnotetext{
${ }^{14}$ Leader firms' innovation efforts depend on the difference between the post- and pre-innovation profits, and both of them decrease with the fall in capital controls. Importantly, pre-innovation profits decrease more, which raises the benefit from innovating. The reason is that capital market distortions affect foreign firms' profits more, the narrower is the technology gap between the foreign firms and their home competitors.
} 
foreign rivals and decrease the technology gap between them. In addition, as home firms are more likely to entry, the productivity gap narrows more in varieties where the initial gap was the largest.

-Proposition 5: Aggregate productivity growth. A decrease in $\tau$ increases aggregate productivity growth $\left(g_{Q t+1}\right)$ :

$$
\frac{\partial g_{Q t+1}}{\partial \tau_{t+1}}<0
$$

As firms increase their innovation efforts, aggregate productivity growth increases. Notably, this expansion stems from the two channels proposed in the paper: better financing terms induce home firms to innovate more, and deeper competition encourages foreign firms to do the same. ${ }^{15}$

Propositions 1-5 provide qualitative implications about the impact of financial liberalization on competition and firms' investment in technology. In the next sections, I use the deregulation of international financial flows in Hungary in 2001 to test these implications.

\section{The Deregulation of International Financial Flows in Hun- GARY}

This section presents the capital controls that were in place in Hungary prior to 2001 and describes the liberalization of international financial flows and its impact on firms' access to external funds. ${ }^{16}$

Prior to 2001, regulations in the foreign exchange (FX) market were the main capital control tool in Hungary. ${ }^{17}$ Foreign exchange operations were regulated by Act XCV of 1995, which employed three main tools to limit international financial flows. It used two tools to restrict banks' ability to intermediate foreign funds and one tool to prevent firms from borrowing internationally. The first tool restricting banks' international financial flows was the ban on currency forward instruments -chiefly among them, FX swaps and forward contracts. These instruments allow hedging against exchange rate fluctuations and, hence, are crucial for banks to raise foreign funds. The second tool was the regulations on the spot market, which required banks' transactions in foreign currency to

\footnotetext{
${ }^{15}$ As discussed above, if the local level of financial development is low, $R_{t+1}^{L}-\mu<R_{t+1}^{*}-\hat{\tau}$, and banks prefer to lend to foreign agents. In this case, the model's predictions are reversed and a reduction in capital controls leads to capital outflows as well as lower competition and productivity growth (Appendix B.5).

${ }^{16}$ This reform was driven by the accession to the European Union. To join the EU, all candidate countries have to accomplish the Copenhagen Criteria of 1993. One of these criteria is that candidates have to ensure free movement of capital, the only missing requirement in Hungary. The reform completed the deregulation of international financial flows. Section 5.1 discusses the identification strategy in detail.

${ }^{17} \mathrm{FX}$ market controls are commonly used to regulate international capital flows, as they restrict agents from acquiring foreign currency, hedging the exchange rate risk and, hence, borrowing or lending internationally. These controls were widely implemented during the Bretton Woods years, when countries had fixed exchange rate regimes (see Smith, Walter, and DeLong 2012). Lately, during the Great Recession, many emerging markets -as, for example, Korea and Brazil- employed them to restrict capital inflows.
} 
be pre-approved by the Central Bank (National Bank of Hungary, NBH) and made the spot FX market very illiquid. ${ }^{18}$ These restrictions substantially limited banks' ability to intermediate foreign funds and made them reluctant to borrow internationally. As a result, banks based their credit supply on domestic savings, which led to a low level of credit. In 2000, Hungary's credit-to-GDP ratio (0.27) was three times smaller than the OECD average (0.86), and its credit-to-deposit ratio was a third lower (0.83 versus 1.2 in OECD countries).

The third tool that Act XCV used to limit international financial flows was the regulation on firms' borrowing in foreign currency. Under this law, only firms declaring to tax authorities that they receive foreign currency income were allowed to borrow in foreign currency. ${ }^{19}$ Crucially, this regulation divided firms into two groups. The first group of firms, domestic firms, were limited to borrowing locally in national currency and, hence, were disproportionally affected by the low level of credit in the local financial system. The second group of firms was composed of foreign companies that, unlike domestic firms, could avoid the local restrictions by directly obtaining international funds. ${ }^{20}$ Although there is no precise record indicating the exact amount of foreign indebtedness at the firm level, there is substantial evidence that foreign firms used these funds intensively. As reported by the IMF (1998), these firms employed two main sources of international funds. First, they enjoyed the relationship between the parent company and its banks to access foreign bank credit. Second, they intensively used internal capital markets with their parent companies. In 1998, more than one-third (35\%) of total credit in the economy was internal credit between parent companies and subsidiaries in Hungary. This use of internal capital markets offers foreign firms financial advantages relative to their local competitors, as shown by Desai, Foley, and Hines (2004); and Desai, Foley, and Forbes (2008), among others.

In this way, FX controls created asymmetric access to international borrowing between domestic and foreign firms. This asymmetry was reflected in differences in firms' financing terms, as implied in the model. The BEEPS indicate that domestic firms paid interest rates that were 3.2 percentage points higher than foreign firms and that the required value of the collateral on total debt was $58 \%$ greater (Table 1). As a result, domestic firms' leverage was a third lower than that foreign firms. In my empirical analysis, I exploit this pre-reform asymmetry to identify the effect of the financial

\footnotetext{
${ }^{18}$ In particular, the regulations in the spot market included a ban on foreign financial investors to participate in the market, restrictions in the amount of interbank lending in foreign currency, and the requirement for banks to apply for individual licenses to acquire foreign currency.

${ }^{19}$ In particular, the Act regulated which firms could have bank accounts in foreign currency. Under this law, only firms reporting to tax authorities that they receive foreign currency income were allowed to apply for convertible accounts, i.e. bank accounts denominated in foreign currency. Without declaring foreign currency income, firms were not allowed to open convertible accounts and, thus, could not borrow in foreign currency.

${ }^{20}$ While the law allowed domestic exporters to borrow internationally, the empirical evidence suggests that they were not obtaining international funds. As discussed in Section 5.2, prior to the reform, domestic exporters had the same level of leverage and financing terms as domestic non-exporters and shared the same post-reform pattern of growth (see Tables A.4 and A.5 in the online Appendix). Notably, even after the financial liberalization, domestic exporters had limited access to international capital markets. In 2004, only fourteen domestic exporters reported that they had debt in foreign markets. In this way, the empirical evidence suggests that Hungarian exporters and non-exporters were similarly constrained from borrowing from abroad. For this reason, I treat these firms similarly and focus on a much sharper contrast revealed in the data: the asymmetric access to international borrowing between foreign and domestic firms.
} 
liberalization within Hungary.

In 2001, Act XCIII removed the regulations in the FX market, namely the ban on forward currency instruments and the restrictions on the spot market and on firms' foreign currency borrowing. The liberalization had a large impact on banks' use of foreign funds. As shown in Figure 1, within the three years before and after the reform (1998-2004), net capital inflows of financial institutions rose from 0.6 to 3.3 billion U.S. dollars per year, and their external debt more than tripled, reaching 20 billion U.S. dollars. In parallel, banks started intensively employing financial derivatives, particularly FX swaps. Both cross-border and local derivatives soared and, by 2004, they had increased by more than three-fold. The increase in banks' liquidity was associated with an expansion in the local credit supply. Table 1 shows that, by 2004, the credit-to-GDP ratio had almost doubled and the credit-to-deposit ratio had grown by more than a third.

Capital inflows led to a decrease in the lending interest rate, which substantially improved financing terms for domestic firms and -as in the model- reduced the asymmetric access to finance across firms. By 2004, the interest rate differential between domestic and foreign firms had fallen five-fold from 3.2 percentage points to 0.65 percentage point, and the difference in the value of the required collateral had dropped four-fold from 58 to 11 percentage points. In addition, data from the NBH reveal that small and medium enterprises increased their share of total credits by 17 percentage points. Importantly, this expansion was driven by credits in FX: by 2004, one-third of their credit was denominated in foreign currency. In the aggregate, the expansion of banks' international borrowing was also reflected in the financial account, whose deficit almost doubled by 2004 (from 3.8 to 6.9 billion of U.S. dollars per year).

The figures above indicate that the financial liberalization in Hungary was associated with capital inflows and with a reduction in the asymmetric access to finance between domestic and foreign firms, as the model illustrates. In the next sections, I employ the model's qualitative implications to assess whether this reduction affects competition and productivity growth.

\section{DATA}

I test the model's predictions using two firm-level databases: APEH, which contains panel data on firms' balance sheets reported to tax authorities and is provided by the Statistical Department of the National Bank of Hungary, and the Business Environment and Enterprise Performance Surveys (BEEPS) of the World Bank and the European Bank for Reconstruction and Development.

The APEH database contains census data on manufacturing firms and spans the period 19922008. This database provides information on firms' value added, sales, output, stock of capital, employment, wages, materials, exports, and ownership structure, which I employ to construct measures of capital intensity (capital per worker), labor productivity (value added per worker), RTFP, markup, and ownership status. To obtain real values, I use price indexes at four-digit NACE industries for materials, investment, value added, and production. The RTFP measure is 
computed using the Olley and Pakes (1996) method to estimate the parameters of the production function. For robustness, I additionally estimate these parameters using De Loecker and Warzynski (2012), Petrin and Levinsohn (2012), and Wooldridge (2009) methodologies. I estimate markups as a wedge between the firm's labor share and the labor elasticity of production. Following the standard literature, I define a firm as foreign if more than $10 \%$ of its shares belong to foreign owners. Beginning in 1999, firms were asked to report short-term debt undertaken with financial institutions. I use this information to construct a proxy for leverage: the short-term debt-to-sales ratio. Since providing this information is optional, only some firms provided it, shrinking the sample of non-missing observations by approximately $50 \%$.

The firm-level analysis in Sections 5.2-5.4 focuses on a balanced panel of 5,548 firms present over the period 1998-2004 and for which there is enough information to compute the RTFP measure. Since smaller firms are more subject to measurement error problems, I retain firms with five or more employees. This balanced panel accounts for $77 \%$ of value added and $70 \%$ of employment in the manufacturing sector. Additionally, I employ the unbalanced panel to conduct several robustness tests and conduct the industry- and aggregate-level analysis in Sections 5.5 and 5.6.

I assess changes in firms' innovation activities using the BEEPS (2002 and 2005). These surveys provide information on all economic activities and employ stratified random sampling to ensure that they are representative of the population of firms. The BEEPS report information on innovation activities and expenditures in R\&D. The surveys ask whether the firm has conducted any of the following activities in the previous three years: developed a major product line, upgraded an existing product line, acquired a new production technology, obtained a new licensing agreement, or obtained a new quality accreditation. ${ }^{21}$ I construct a dummy variable (Innovation) if the firm has undertaken any of these activities and a dummy variable $(R \& D)$ if the firm reports $R \& D$ spending. The surveys also report information on firms' financing terms - cost of loans and the value of the collateral required on total loans- which I employ in Section 5.3.

To test the financial channel, I use information on sector dependence on external finance from Raddatz (2006), who re-estimated the financial dependence index of Rajan and Zingales (1998) for U.S. listed firms at the four-digit industry level. This index measures the amount of investment that cannot be financed through internal cash flows and is used as a proxy for sectors' technological needs for external finance. As capital markets are largely advanced in the United States and listed firms are less likely to be credit constrained, this index tends to capture the technical needs for external finance in the sector. Using an index estimated for U.S. firms avoids endogeneity concerns. ${ }^{22}$

\footnotetext{
${ }^{21}$ These measures of innovation follow the recommendations of the Oslo Manual developed by the OECD and Eurostat for innovation surveys. This definition of innovation focuses on new and improved product and processes that are "new to the firm". This emphasis on "what is new to the firm" is of special interest to this study because Hungary is a developing economy, and the easing of credit conditions might have encouraged more domestic firms to adopt frontier technologies rather than develop new ones. Importantly, the majority of firms (75\%) have reported that these activities were a critical contributor to their growth. See also Gorodnichenko and Schnitzer (2013).

${ }^{22}$ More precisely, Rajan and Zingales (1998) define needs for external finance as firms' capital expenditures minus cash flows from operations divided by capital expenditures for U.S. listed firms. Then they use the sector median value to construct the dependence on external finance for each industry at the three-digit level.
} 


\section{EMPIRICS}

This section assesses the impact of the financial liberalization in Hungary on market competition and firms' investment in technology. I employ the model's qualitative implications to guide the empirical analysis. In Section 5.1, I start by describing the identification strategy. In Sections 5.2 and 5.3, I test whether domestic firms expanded more than foreign firms in terms of investment in technology (Proposition 1) and whether this expansion correlates with an increase in leverage (Proposition 2). In Sections 5.4 and 5.5, I evaluate whether deeper competition leads to reductions in foreign firms' markups (Proposition 3) and changes in the productivity gap within sectors (Proposition 4). In Section 5.6, I assess whether aggregate productivity growth accelerates (Proposition 5) and explore the source of this growth.

\subsection{Identification Strategy}

This section presents the identification strategy and discusses possible concerns regarding the empirical analysis, for example, differences in firms' initial characteristics and previous growth trends, differences in industrial patterns of growth, sample selection, and reverse causality.

The identification strategy of the effect of financial liberalization is based on the asymmetric access to international capital markets for domestic and foreign firms prior to the reform. I exploit this source of cross-sectional variation to test the two forces proposed in this paper. I test the first force -financial liberalization encouraging home firms' investment in technology- in two steps. I first estimate the differential impact of the reform on domestic firms' investment. I next examine the financial channel by adding another source of cross-sectional variation: sector financial needs. That is, I exploit three sources of variation -time, sector reliance on external finance, and firms' access to international borrowing prior the reform- to assess whether home firms with greater needs for external finance expand more after the liberalization. I complement this analysis by using direct information on firms' leverage and financing terms to test whether home firms increase the use of bank credit. To test the second force -financial liberalization deepening competition- I exploit variations in terms of sector financial needs. Since the asymmetric access to international borrowing has a more distortionary effect on competition in sectors in which domestic firms employ external finance more intensively, the deepening of market competition is relatively greater in those sectors. Hence, I exploit differences in sector financial needs to identify the pro-competitive forces on foreign firms across sectors.

To identify the effect of the reform, it is important to determine whether domestic and foreign firms differed in characteristics that could involve heterogeneous patterns of investment and productivity growth. If these differences were not accounted for, the estimated coefficients could be biased. Table 2 breaks down the data into domestic and foreign firms and presents sample means in the initial year (1998) by type of firm. Prior to the reform, foreign firms were older; were larger in terms of value added, employment, labor productivity, and RTFP; and enjoyed higher markups. 
These firms also had a higher probability of conducting innovation and R\&D activities, as shown in Table 3. Since the difference in means in these variables is statistically significant, I control for them in my reduced-form regressions.

A main assumption of the empirical strategy is that before the reform, firms shared similar growth trends. Indeed, a first glance at the data confirms that domestic and foreign firms saw similar patterns of growth within the five years preceding the reform (1996-2000). Figure 2 plots the evolution of the main outcomes analyzed: labor productivity, RTFP, capital intensity, markups, and leverage. Values are normalized to their initial levels. Remarkably, these parallel patterns of growth reversed after the reform. In line with the theory proposed in this paper, following the liberalization, the average domestic firm grew faster in terms of labor productivity, RTFP, capital intensity, and leverage. Also, consistent with the model's predictions, foreign firms' markups shrank faster. The analysis of the sample means confirms that the growth rates of foreign and home firms were not statistically different over the five years before the deregulation (Table 4).

The previous paragraph discussed the concern over firms' pre-existing growth trends. If domestic firms were correlated with some industry characteristics, however, it would be necessary to control for them to rule out possible sources of bias. I estimate the equations in first differences, so that time-invariant industry characteristics are differenced out. However, if sectors with different initial characteristics were on different trends, the estimated coefficient could capture some omitted industry-level time-dependent variable. I tackle this issue in three different ways. First, to account for sectoral pre-existing growth trends, I include the capital intensity and productivity growth at the four-digit NACE industry level in Hungary before the reform (1996-1997). Second, since sectors' investment and productivity could be growing at a different pace in the global economy, I also control for capital intensity and productivity growth in the United States. Third, as a robustness test, I also consider sector and sector-year fixed effects at the four-digit NACE industry level.

A critical hypothesis underlying the study is that the sample is not subject to selection issues; that is, pro-competitive forces may affect not only firms' outcomes but also the probability of a firm being observed. If this probability differed between domestic and foreign firms over time, the conditional expectations on the OLS residuals would be different from zero and the estimated coefficients would be biased (see Heckman 1974 and Heckman 1979). To assess whether this missing data problem challenges my estimations, I check whether there are differences in the probability of domestic and foreign firms being observed. In particular, I define a surviving firm if it existed the year before the reform (2000) and did not exit within the three years following it. Next, I compute the survival ratio of domestic and foreign firms and test whether there are differences in their means. Results show no statistically significant difference between the survival probability of domestic and foreign firms, and suggest that this missing data problem does not affect the estimated coefficients (Table A.1 in the online Appendix).

The general context around the reform and its timing makes it likely to be exogenous with respect to the main outcome analyzed, i.e. changes in home firms' investment in technology. The reform was driven by the accession of transition economies to the EU. The requirements to join the 
EU were predetermined by the Copenhagen Criteria in 1993 and have been equal for all accessing countries since then. In this sense, the content of the reform was exogenous to the country's political choice. As the agenda was jointly determined by the European Council and the candidate countries, it is unlikely to have been driven by political pressure from Hungarian firms. ${ }^{23}$

Even though the preceding points address the reverse causality problem, any event occurring in the years around the reform and affecting firms' investment choices differentially could affect the estimated coefficients. To identify the effect of the reform, I restrict the analysis to the three years preceding and following it. Importantly, during this period, no other significant event that could differentially affect firms' investment in technology occurred in Hungary. First, the economy was growing at a steady pace, with no significant shock in these years. Notably, real external flows -as trade and foreign direct investment- remained constant. ${ }^{24}$ Second, major reforms had already taken place during the early 1990s, such as privatization of public companies, bank deregulation, and competition laws. ${ }^{25}$ Third, the EU did not require any further reform that could affect the development of the manufacturing sector. Finally, the Hungarian economy was already deeply integrated with the EU. This integration was remarkable in the manufacturing sector: this sector's exports to the EU already accounted for $80 \%$ of total exports in 2001 (Figure A.2). It is worth mentioning that the patterns of capital inflows observed in Hungary cannot be attributed to the joining of the EU, as the timing does not coincide with the accession, and other similar candidates with already deregulated financial accounts do not show the pattern of capital inflows observed in Hungary (Figure A.3). Notice that Hungary did not join the Euro zone and, hence, did not have to fulfill any monetary or fiscal criteria.

\subsection{Impact on Home Firms' Investment}

As discussed above, the deregulation of international financial flows in Hungary led to capital inflows and to a reduction in the asymmetric access to external finance between domestic and foreign firms. Proposition 1 states that this reduction encourages home firms to increase their investment in technology. In this section, I assess this prediction in two steps. I first study whether domestic

\footnotetext{
${ }^{23}$ It is worth mentioning that, given the speed of the reform, it is unlikely that firms anticipated it and undertook investment in advance. In December 2000, the European Council defined the timing for the accession vote and the last requirements to be met by each candidate. The reform had to take place before the accession vote in December 2002. Soon after the European Council meeting, in March 2001, Hungary deregulated the remaining controls on financial flows.

${ }^{24}$ During the years preceding and following the reform, FDI remained constant and even showed a small slowdown following the deregulation (see Figure A.4). Moreover, Hungarian external trade did not seem to have particularly suffered from the world recession in 2001. The volume of exports and imports continued to grow during that period (Figure A.5).

${ }^{25}$ Major privatization programs occurred in the early 1990s, and by 1997, the share of public companies in manufacturing value added was only $2 \%$. The Competition Act entered into force in 1997, and according to the Hungarian Competition Authority, the accession to the EU did not cause a major change in this field. The banking sector had already achieved a major transformation by 1997, and neither banking concentration nor its efficiency changed around the liberalization. In particular, according to data from Beck, Demirguc-Kunt, and Levine (2010), there were no changes in banks' concentration index, interest rate margin, overhead costs-to-assets ratio, nor cost-income ratio (Figure A.1). Furthermore, the number of credit institutions did not change (Table A.2).
} 
firms increase their capital intensity and productivity. Then I turn to test whether they expand their R\&D and innovation activities.

\section{Investment in Capital and Productivity}

I analyze the differential impact of the liberalization of international financial flows on domestic firms' capital and productivity considering the following model:

$$
y_{i t}=\delta_{0} H_{i}+\delta_{1} T_{t}+\delta_{2}\left(H_{i} \times T_{t}\right)+\varepsilon_{i t},
$$

where $i$ indexes firms, $t$ denotes time, $H$ is a dummy variable for domestic firms, $T$ is dummy variable for the post-reform period, and $y$ is a vector of \{capital intensity, labor productivity, and RTFP . The coefficient of interest is $\delta_{2}$ and captures the impact of the reform on domestic firms' outcomes.

A potential pitfall of regression (7), estimated with yearly firm-level data, is that residuals could be serially correlated -across time within firms and across firms within sectors for a given year. Serial correlation in the error term might understate the OLS standard errors and induce a type II error, i.e. rejecting the null hypothesis when this is true. To account for this source of bias in the OLS standard errors, I use one of the solutions proposed by Bertrand, Duflo, and Mullainathan (2004) and remove the time series dimension of the data. More precisely, I aggregate the data into pre- and post-reform periods, defined as the three years before and after the deregulation. ${ }^{26}$ The dependent variable is computed as the average value between 1998 and 2000, and between 2002 and 2004:

$$
\Delta y_{i}=\log \left(\frac{1}{3} \sum_{2002}^{2004} y_{i t}\right)-\log \left(\frac{1}{3} \sum_{1998}^{2000} y_{i t}\right) .
$$

Equation (7) in first differences becomes

$$
\Delta y_{i}=\delta_{1}+\delta_{2} H_{i}+\Delta \varepsilon_{i}
$$

I cluster the OLS standard errors at the four-digit NACE industry level to take into account the correlation across firms within sectors. Regression (8), in first differences, removes firm- and sectorfixed effects and therefore controls for time unvarying unobserved characteristics at the firm and industry levels. However, the fixed effects do not absorb individual characteristics that could lead firms to benefit differently from the introduction of the reform. When estimating equation (8), I therefore add a set of initial conditions at the firm level, $Z_{i}$, as size (employment), productivity

\footnotetext{
${ }^{26}$ Notice that, as the reform took place in the middle of 2001 , this year is only a partially treated year and, hence, does not belong to either of the two groups. As the purpose of the analysis is to estimate the average effect of the policy, it would be misleading to include it in either of the groups. For this reason, I drop the year 2001 in the main specifications. Importantly, I show below that all results are robust to its inclusion when estimating the effect of the reform by year (Tables A.11, A.17, A.18, and Figure 3).
} 
(RTFP), and age at the initial year (1998). As sectors could be on different trends, I control for pre-existing growth trends of RTFP and capital intensity at the four-digit NACE industry level between 1996 and 1997 in Hungary, $X_{j}$. To account for differences in industry growth trends in the world economy, I add the following as controls: capital intensity and TFP growth at the four-digit level in the United States between 1998 and 2004, $\psi_{j}$. The statistical model I estimate is

$$
\Delta y_{i j}=\delta_{1}+\delta_{2} H_{i}+\delta_{3} Z_{i}+\delta_{4} X_{j}+\delta_{5} \Delta \psi_{j}+\Delta \varepsilon_{i j}
$$

The estimation of equation (9) by OLS is reported in Table 5 . The coefficient for capital intensity estimated in the baseline specification of column 1, where only the dummy for the domestic firm is included as a regressor, implies a differential expansion of these firms' capital intensity by $0.239 \log$ point $(t=10.24)$. The estimated coefficient is not affected by the inclusion of firm-level controls in column 2 nor by the inclusion of local and global trends in column 3, and remains stable across estimations. Results for labor productivity are presented in columns 4-6. The baseline specification in column 4 indicates a differential impact for domestic firms of $0.074 \log$ point $(t=4.35)$. The inclusion of firm and industry controls does not significantly affect the estimated coefficient, which stands at $0.053 \log$ point $(t=3.36)$. The estimates for RTFP confirm the greater expansion in productivity for home firms. After controlling for firm and sector characteristics, the estimated coefficient in column 9 shows a differential increase of 0.032 logs point $(t=2.03)$ for domestic firms.

In the online Appendix, I present a full set of robustness tests. Table A.3 shows that results are robust to control for four-digit industry fixed effects (column 1), wholly foreign companies (column 2), foreign firms used as export platforms (column 3), 1\% of top firms (column 4), and firms that change their ownership status (column 5). The empirical evidence does not suggest any significant difference between domestic exporters and non-exporters, as i) they faced similar leverage and financing terms -interest rate and collateral- prior to the liberalization (Table A.4), and ii) they showed non-statistically different patterns of growth in the post-reform period (Table A.5). Additionally, I show that the RTFP results are robust to De Loecker and Warzynski (2012), and Petrin and Levinsohn (2012) (with Wooldridge's 2009 correction) measures (Table A.6). Importantly, results are robust to controlling for firms' subsidies and tax exemptions, for four-digit industry-year fixed effects, and to considering the unbalanced panel and firms with fewer than five employees (Tables A.7, A.8 and A.9). Home firms' expansion is widespread across manufacturing sectors (Table A.10).

Equation (9) pooled the estimated effect across all years before and after liberalization. To check whether the estimates are capturing the effect of the financial liberalization and not something else, I test whether the timing coincides with the deregulation. To this end, I interact the dummy for home firms with year dummies and re-estimate equation (9) using four-digit NACE industry level fixed effects. In this way, I compare domestic and foreign firms within each four-digit industry and test whether domestic firms evolve differentially over time. Results are presented in Table A.11 and plotted in Figure 3. The estimated coefficients for the interaction terms are statistically sig- 
nificant, confirming that domestic firms were smaller in size (capital intensity, labor productivity, and RTFP) than their foreign-industry competitors. Importantly, while the estimated coefficients do not change significantly before the reform, they monotonically decrease after it. These results suggest that home firms grew much faster and gradually closed the gap between the home firms and their foreign rivals (Figure 3). The F-test on equality of coefficients confirms these results. While the estimated coefficients for the interaction terms are not statistically different from 1998 to 2000, they differ significantly when comparing the pre-reform and post-reform years (Table A.11). As a further falsification test, I estimate a placebo test on the year 1998 and estimate equation (9) for the period 1996-2000, with a two-year window. The results, presented in Table A.12, show that during this period, domestic firms did not evolve differently from their foreign competitors.

\section{R\&D and Innovation Activities}

To assess whether domestic firms increased their R\&D and innovation activities after the liberalization, I employ the BEEPS and estimate the following model:

$$
y_{i j t}=\delta_{0} H_{i t}+\delta_{1} T_{t}+\delta_{2}\left(H_{i t} \times T_{t}\right)+\delta_{3} Z_{i t}+\mu_{j}+\varepsilon_{i j t},
$$

where $t$ denotes year; $T$ is a dummy indicating the reform period; $j$ represents sectors (which break down into eight categories); $y_{i j t}$ is a dummy for whether the firm conducts R\&D or innovation activities; and $Z_{i t}$ is a vector of firm characteristics: age and size (employment). ${ }^{27}$ To control for sector-specific characteristics, I add sector fixed effects: $\mu_{j}$. I cluster standard errors at the sector level. Equation (10) with fixed effects cannot be consistently estimated by probit (incidental parameters problem), so I estimate a linear probability model. The coefficient of interest is $\delta_{2}$, which identifies the change in the probability of domestic firms undertaking R\&D and innovation activities after the reform.

Columns 1-3 in Table 6 report the results on R\&D activities. The baseline specification suggests that the reform increased the probability of domestic firms undertaking $R \& D$ activities by 10.7 percentage points $(t=2.24)$. The estimated coefficient remains stable and statistically significant after the inclusion of firm- and industry-level controls (columns 2 and 3). Along the same lines, results on innovation activities in columns 4-6 also suggest that the reform increased the probability of domestic firms conducting these activities. The coefficient in the regression including all controls (column 6) implies an increase of 12 percentage points $(t=2.19)$.

\footnotetext{
${ }^{27}$ As few firms report data on sales, controlling for firms' productivity greatly reduces the sample. Importantly, results are robust to this control.
} 


\subsection{Investigating the Financial Channel}

The previous section showed that domestic firms differentially expanded their capital intensity and productivity after the reform. This section assesses in two steps whether this expansion correlates with a greater use of external funds, as implied by the financial liberalization. I first evaluate whether domestic firms grow more when they are more dependent on external finance and, hence, more exposed to the reform. Next, I take Proposition 2 to the data and test whether -after controlling for firms' observable characteristics- financial terms decrease for domestic firms and whether they increase their leverage accordingly.

\section{Investment in Capital and Productivity}

I start assessing the financial channel by exploiting an additional source of cross-sectional variation: sector needs for external finance. Importantly, this third source of variation allows for an assessment of the two forces proposed in this paper: better financing terms encouraging domestic firms' investment in technology and reductions in capital market distortions triggering pro-competitive forces on foreign firms. Regarding the first force, sector financial needs allow for testing whether domestic firms expand relatively more when they operate in sectors that rely intensively on external finance. Concerning the second force, differences in sector financial needs allow for an assessment of whether competition tightens more in sectors that are initially more distorted. Intuitively, since the asymmetric access to international capital markets distorts competition more in sectors where external funds are employed more intensively, competition should deepen relatively more in these sectors. As such, foreign firms should also increase their productivity in accordance with sector financial needs. Importantly, since the distortion has a greater effect on domestic firms' innovation incentives (Proposition 1), conditional on the sector, home firms should expand relatively more.

To evaluate these two channels, I include sector financial needs in equation (7) and consider the following model:

$$
y_{i t}=\delta_{0} H_{i}+\delta_{1} T_{t}+\delta_{2}\left(H_{i} \times T_{t}\right)+\delta_{3}\left(F D_{j} \times T_{t}\right)+\delta_{4}\left(H_{i} \times F D_{j} \times T_{t}\right)+\delta_{5} F D_{j}+\delta_{6}\left(H_{i} \times F D_{j}\right)+\varepsilon_{i t},
$$

where $j$ denotes four-digit NACE industries and $F D_{j}$ is the index of external finance of Rajan and Zingales (1998) at four-digit NACE industries. ${ }^{28}$ Coefficient $\delta_{3}$ captures the differential impact of the reform on foreign firms across sectors. A positive and significant coefficient implies that foreign firms expanded more in sectors where the need for external finance was greater. Coefficient $\delta_{4}$ absorbs the differential impact of the reform on domestic firms across sectors. Importantly, it reflects whether home firms expand relatively more than their foreign industry rivals with the same level of reliance on external funds.

As discussed earlier, a potential pitfall of estimating equation (11) using yearly firm-level data is that residuals could be serially correlated. To avoid serial correlation in the error term, I estimate

\footnotetext{
${ }^{28}$ See Ilyina and Samaniego (2011) for a further discussion about sectors' technological needs for external finance.
} 
equation (11) in first differences. After the inclusion of firm-level and sector controls, the final model I estimate is

$$
\Delta y_{i j}=\delta_{1}+\delta_{2} H_{i}+\delta_{3} F D_{j}+\delta_{4}\left(H_{i} \mathrm{x} F D_{j}\right)+\delta_{5} Z_{i}+\delta_{6} X_{j}+\delta_{7} \Delta \psi_{j}+\Delta \varepsilon_{i j} .
$$

Similarly to equation (11), $\delta_{3}$ captures the effect of the reform on foreign firms across sectors. The coefficient $\delta_{4}$ absorbs the differential effect of home firms over their foreign rivals in accordance with sector financial needs. I control for firm-initial characteristics as well as sector pre-growth trends in Hungary and global trends, and cluster the standard errors at four-digit NACE industries, as in equation (9).

Columns 1-3 in Table 7 report the results on capital intensity. The coefficient on the interaction term for home firms $\delta_{4}$ is statistically significant in all specifications. After including all controls (column 3), the estimated coefficient implies that one standard deviation increase in the index of external finance raises domestic firms' capital intensity by $0.045 \log$ point $(t=2.02)$. It is important to remark on the estimated coefficient for foreign firms, $\delta_{3}$. This coefficient is not statistically significant in any specification, showing that foreign firms did not expand their capital intensity in accordance with sector financial needs. Notably, this lack of correlation between the need for external finance and capital investment suggests that foreign firms were not credit constrained nor in need of external funds before the liberalization.

Columns 4-6 present the results for labor productivity. The coefficient $\delta_{3}$ on the pro-competitive forces on foreign firms across sectors shows that one standard deviation increase in the index of financial dependence leads to an expansion of $0.09 \log$ point $(t=2.50)$ in foreign firms' labor productivity after the inclusion of firm- and industry-level controls in column 6 . As predicted by the model, the expansion is higher for domestic firms: the coefficient $\delta_{4}$ implies an expansion of $0.04 \log$ point $(t=3.17)$ relative to their foreign competitors in the same sector. Results on RTFP confirm the pattern of growth in labor productivity (columns 7-9). After considering all controls, the estimated coefficient indicates that one standard deviation increase in the index of financial dependence raises foreign firms' RTFP by $0.08 \log$ point $(t=3.02)$ (column 9$)$. As in the trends in labor productivity, the estimated coefficient implies that domestic firms expanded relatively more: their RTFP grew by $0.05 \log$ point $(t=2.48)$ more than that of their foreign rivals.

These results provide support for the two forces proposed in this paper. First, consistent with the greater exposure to the reform, domestic firms with higher sectoral needs for external funds expanded their capital intensity and productivity relatively more. Second, in line with the presence of pro-competitive forces, foreign firms increased their productivity in sectors where competition was initially more distorted. ${ }^{29}$

The online Appendix presents four additional robustness tests. First, I re-estimate equation (11) non-parametrically by splitting the sample into quartiles of dependence on external finance. Results presented in Table A.13 confirm that home firms expanded monotonically with the level of

\footnotetext{
${ }^{29}$ This evidence is also consistent with previous industry-level studies reporting that increases in competition induce incumbent firms to raise their productivity (see, for example, Holmes and Schmitz 2010).
} 
financial dependence and that the increase is significantly larger in the third and fourth quartiles. Second, to test whether the response of foreign firms corresponds to tighter competition and not to financial constraints on these firms, I estimate whether their responses vary when considering different ownership structures. In particular, the presence of pro-competitive forces should remain true even when considering foreign firms that are tightly linked to their parent companies and, thus, are less likely credit constrained. To test this, I estimate regression (12) on foreign firms with more than $50 \%$ foreign shares and show that the estimated coefficients on labor productivity and RTFP remain positive and statistically significant even for this group of foreign firms (Table A.14). Third, I show that the pro-competitive effects remain true after excluding foreign firms that export more than $75 \%$ and $90 \%$ of their sales and, hence, operate as export platforms (Table A.15). Finally, to check whether the increase in firms' productivity is in line with a more intensive use of technology, I construct a measure of skill intensity and test whether firms employ more skilled labor after the liberalization. ${ }^{30}$ Results presented in Table A.16 confirm that foreign firms increase their skill intensity in accordance with sector financial needs and, as in the previous trends, home firms expand their skill intensity relatively more in these sectors.

\section{Financing Terms and Leverage}

Proposition 2 states that lowered financial costs following the liberalization allow domestic firms to increase their leverage. I turn to assess this proposition by evaluating whether financing terms improve for home firms and whether, as a result, they increase their leverage.

The BEEPS request firms to report the interest rate paid on loans and the value of the required collateral. I use this information as outcome variables to regress equation (10) and report the results in Table 8. Confirming that home firms faced tighter financing terms than foreign firms prior to the reform, the estimated coefficients indicate that the interest rate that domestic firms paid was 3.7 percentage points $(t=3.55)$ higher than foreign firms, and their required collateral was 52 percentage points $(t=4.63)$ greater, after the inclusion of all controls in columns 3 and 6. As expected, the liberalization improved financing terms for home firms: their interest rate fell by 3.9 percentage points $(t=3.67)$, and the required collateral fell by 31.2 percentage points $(t=$ 2.86) (columns 3 and 6).

I examine changes in firms' leverage by using the APEH database to estimate regression (9) on the debt-to-sales ratio. Results presented in Table 9 confirm that domestic firms increased their

\footnotetext{
${ }^{30}$ These data come from the NBH, which conducts a representative labor survey at the firm level for the years 1999-2004, collecting information on employees' education level. Following Bustos (2011), I construct this measure as the share of skilled labor in total employment in primary school equivalents. I define skilled workers (S) as college graduates plus tertiary education graduates converted to college equivalents, and unskilled workers (U) as high school and primary school graduates converted to primary school equivalents. The conversion of workers to college and primary school equivalents was done using the 1998 industrial sector wage premium. More formally, skill intensity is measured as
}

$$
S K_{(i, t)}=\frac{S_{(i, t)}\left(w_{s} / w_{u}\right)_{1998}}{S_{(i, t)}\left(w_{s} / w_{u}\right)_{1998}+U_{(i, t)}} .
$$


leverage after the reform. The baseline regression, where only a dummy for domestic firm is included, indicates a differential increase of $0.16 \log$ point $(t=2.17)$ for domestic firms (column 1$)$. The inclusion of firm- and industry-level controls suggests a slightly larger increase of 0.23 log point $(t=2.61)$. As expected, column 4 shows that the increase in leverage is larger for firms operating in sectors with greater needs for external finance: one standard deviation increase in the index of financial dependence raises domestic firms' leverage by $0.15 \log$ point $(t=1.98)$. Importantly, consistent with the interpretation of the previous section that foreign firms were not credit constrained before the liberalization, foreign firms did not increase their leverage in accordance with sector financial needs. Instead, the estimated coefficient is negative and statistically significant, which could indicate a reallocation of financial funds towards domestic firms, as suggested above.

To test whether the expansion of domestic firms' debt really coincides with the timing of the financial liberalization, I estimate the effect by year. Results plotted in Figure 3 show that the increase in domestic firms' leverage only starts in 2001 and monotonically increases after it. The F-test of equality of coefficients presented in Table A.17 confirms these results. While during the years prior to the reform, the estimated coefficients on domestic firms' leverage were not statistically different, following the liberalization, they monotonically and significantly differ.

The results presented above provide support for the financial channel implied by the liberalization, as lowered financing terms allowed domestic firms to expand. The empirical evidence also argues for the presence of pro-competitive forces, as foreign firms increased their productivity in sectors where competition deepened the most. The next section advances the analysis of procompetitive forces by studying changes in foreign firms' markups.

\section{$5.4 \quad$ Foreign Firms' Markups}

Proposition 3 states that the improvement in financing terms for domestic firms deepens market competition and leads to a reduction in foreign firms' markups. I now turn to test this implication.

To compute firms' markups, I follow De Loecker and Warzynski (2012) and derive them from the firm's optimal labor demand equation:

$$
\begin{gathered}
w_{t} l_{i j t}=\beta_{j} y_{i j t} \frac{\left(\frac{w_{t}}{\beta}\right)^{\beta}\left(\frac{R_{t}}{\alpha}\right)^{\alpha}}{q_{i j t}}, \\
\xi_{i j t}=\frac{1}{\theta_{i j t}} \beta_{j}
\end{gathered}
$$

where $l$ is the firm's optimal labor demand and $y$ is its production; $\beta_{j}$ is the estimated labor elasticity of the production function in sector $j ; w$ denotes the wage and $R$ the interest rate; $q$ expresses the firm's productivity; and $\theta$ represents the firm's labor share. As shown in equation (13), markups $\xi$ are defined as a wedge between the firm's labor share and the labor elasticity of 
production. I test for the differential decline in foreign firms' markups using the following model:

$$
\Delta \xi_{i j}=\delta_{1}+\delta_{2} F_{i}+\delta_{3} Z_{i}+\delta_{4} X_{j}+\delta_{5} \Delta \psi_{j}+\Delta \varepsilon_{i j}
$$

where $F_{i}$ is a dummy for foreign firms. In this model, $\delta_{2}$ captures the differential impact of the reform on foreign firms' markups. I control for firms' initial characteristics as well as local and global trends, and cluster the standard errors at the four-digit industry level as in equation (9).

Column 1 in Table 10 shows changes in markups regressed on a dummy for a foreign firm. As predicted by the model, the estimated coefficient suggests a greater decrease in foreign firms' markups of $0.017 \mathrm{log}$ point $(t=1.9)$ relative to domestic firms. The inclusion of firm- and industrylevel controls does not significantly affect the results: on average, foreign firms' markups drop by $0.026 \log$ point $(t=2.26)$. This relative decrease in foreign firms' markups is consistent with the evidence presented in the previous sections and the model's implications. As domestic firms differentially increase their productivity, foreign firms' cost advantage decreases and, therefore, their markups fall relatively more. Note as well that the magnitude of the relative drop in foreign firms' markups (0.026 log point) is in line with the relative increase in domestic firms' RTFP (0.032 $\log$ point).

For robustness, I compute markups using the elasticities of the production function estimated with the De Loecker and Warzynski (2012) and Petrin and Levinsohn (2012) (with Wooldridge's 2009 correction) methodologies. Table A.6 confirms the decline in foreign firms' markups following the financial liberalization and shows that this reduction is robust to either estimates of the production function (Cobb-Douglas in the first case, and translog in the second). Results are also robust to using the price-cost margin, which proxies markups as firm's sales minus total costs over sales following Aghion, Bloom, Blundell, Griffith, and Howitt (2005) (see column 3 of Table A.6). Additionally, I estimate equation (14) by year and test whether this decline coincides with the timing of the reform. Results plotted in Figure 3 and presented in Table A.18 confirm the decrease in foreign firms' markups since 2001. As demonstrated by the F-test, the estimated coefficients on foreign firms' markups were not statistically different between 1998 and 2000, but they monotonically and significantly differ in the years following the reform. I also estimate a falsification test for 1998 and show that foreign firms' markups did not change differently regarding their local competitors prior to 2001 (Table A.19). ${ }^{31}$

As discussed above, asymmetric access to international capital markets undermines the competitive pressure of domestic firms to a greater extent in sectors requiring more intensively external finance. This weaker competition allows foreign companies to obtain higher markups. Hence, financial liberalization should be associated with a greater decline in foreign firms' markups in more financially dependent sectors. To assess this implication, I test whether foreign firms' markups differentially decreased in these sectors by interacting the dummy for foreign firms with the financial

\footnotetext{
${ }^{31}$ Results on foreign firms' markups are robust to controlling for subsidies and tax exemptions (Table A.20) and firms with fewer than five employees (Table A.21).
} 
dependence index of Rajan and Zingales (1998). The estimated equation is

$$
\Delta y_{i j}=\delta_{1}+\delta_{2} F_{i}+\delta_{3} F D_{j}+\delta_{4}\left(F_{i} \times F D_{j}\right)+\delta_{5} Z_{i}+\delta_{6} X_{j}+\delta_{7} \Delta \psi_{j}+\Delta \varepsilon_{i j},
$$

where $\delta_{4}$ absorbs the differential effect on foreign firms in more financially dependent sectors. The estimated coefficients are reported in column 4 of Table 10 and indicate that the reform is associated with a relatively greater decline in foreign firms' markups in those sectors. Foreign firms operating in one standard deviation more financially dependent sector experience a $0.05 \log$ point $(t=4.74)$ larger decline in their markups. Importantly, this differential decrease in foreign firms' markups across sectors remains true when estimating markups using different methodologies (Table A.22) and controlling for foreign firms that operate as export platforms (Table A.23). Note, finally, that this greater decline in foreign firms' markups in more financially dependent sectors is consistent with the greater expansion of domestic firms in those sectors. It is interesting that the coefficient on financial dependence for domestic firms $\delta_{3}$ is positive and significant, suggesting that their markups rose in sectors with higher financial needs. This result is in line with the greater productivity expansion observed in those sectors. As domestic firms' productivity grew, so did their markups.

\section{Firm-Level Evidence: Taking Stock}

Sections 5.2 to 5.4 tested the model's firm-level implications using data. First, I have shown that the liberalization in Hungary is associated with increases in domestic firms' capital intensity, labor productivity, and RTFP, and in their probability of conducting R\&D and innovation activities, in line with Proposition 1. Second, I have provided direct evidence that domestic firms' expansion correlates with an improvement in financing terms and an increase in leverage, as stated in Proposition 2. Third, the empirical results also point to the presence of pro-competitive forces as foreign firms' markups decreased (Proposition 3), particularly in sectors where competition was initially

more distorted. Furthermore, in those sectors, foreign firms expanded their labor productivity, RTFP, and skill intensity.

\subsection{Industry-Level Evidence: Technological Gap and Concentration}

Proposition 4 states that the greater increase in domestic firms' innovation efforts yields a decline in the productivity gap between the domestic firms and their foreign-industry rivals, and that this decline is greater in sectors where the initial productivity gap was widest. The previous sections have shown that domestic firms have expanded their productivity to a relatively greater extent than their foreign competitors, arguing for a reduction in the productivity gap between them. In this section, I test whether this decline is higher in sectors where the initial gap was larger and whether it is parallel to changes in industry concentration.

Proposition 4 refers to the gap in physical productivity between foreign and domestic firms. 
Unfortunately, the lack of information on firms' prices does not allow for recovering their physical productivity and, thus, assessing this proposition directly against the data. However, through the lens of the model, markups and RTFP are proportional to the productivity gap and, hence, can be employed as proxies for it (see equation (2) and Appendix B.1). Therefore, one could regress

$$
\Delta \kappa_{j}=\alpha+\beta \kappa_{j}+\varepsilon_{j}
$$

where $\kappa_{j}$ denotes the markup or RTFP difference between the 50th percentile foreign and home firms in each three-digit industry $j$ before the reform (1998-2000), and $\Delta$ denotes the change between the pre- and post-reform period (1998-2000 and 2002-2004). A negative $\beta$ would imply that the productivity gap fell more in sectors where the initial gap was largest. A potential drawback of this regression is that it does not consider pre-existing trends within sectors. To account for this, I include a third period of analysis, 1996-1997, and estimate the following model:

$$
\Delta \kappa_{j t}=\alpha+\beta_{1} \kappa_{j t}+\beta_{2} T_{t}+\beta_{3}\left(\kappa_{j t} * T_{t}\right)+\varepsilon_{j t},
$$

where $t$ denotes the period, and $T_{t}$ is a dummy indicating the reform. The change after the reform, taking into account pre-existing trends, is captured by the coefficient $\beta_{3}$ of the interaction term.

Table 11 reports the results for the RTFP and markups gaps. In line with Proposition 4, it shows a greater decrease in the RTFP gap in sectors where its initial level was larger. After the inclusion of historial trends in column 3, the estimated coefficient implies that an increase of one standard deviation in the initial RTFP dispersion narrows the RTFP gap between foreign and domestic firms by $15 \%$ following the reform. Similarly, the estimated coefficient for markups is negative and statistically significant, indicating that an increase of one standard deviation in the initial markup dispersion narrows the markup gap between foreign and home firms by 13\% (column 6 ). The reduction in the RTFP and markup gaps within sectors should be parallel to a decrease in the level of industry concentration, particularly in sectors that were initially more concentrated. ${ }^{32}$ To test this, I follow Nickell (1996) and Aghion, Bloom, Blundell, Griffith, and Howitt (2005), and use the Lerner index as a measure of concentration. Column 9 in Table 11 confirms that the liberalization is associated with a larger decrease in the Lerner index in sectors that were initially more concentrated. After the inclusion of pre-existing trends, the estimated coefficient implies that an increase of one standard deviation in the initial Lerner index drops the industry concentration by $3 \%$ following the reform.

\footnotetext{
${ }^{32}$ Prior to the reform, the Hungarian manufacturing sector presented high levels of market concentration. Foreign firms' share in total value added was $74 \%$, and the Lerner and Herfindahl indexes of industry concentration were high at 0.22 and 0.40 . Importantly, by 2004, market competition had increased: foreign firms' market share had dropped 6 percentage points, and the Lerner and Herfindahl indexes had shrunk by $10 \%$ and $7.5 \%$.
} 


\subsection{Aggregate Productivity Growth}

This section assesses whether the expansion in firms' productivity correlates with an increase in aggregate productivity growth, as stated in Proposition 5. Additionally, it conducts a decomposition exercise to understand the contribution of within-firm and reallocation effects in aggregate productivity growth.

In the late nineties, aggregate productivity was growing at a fast pace in Hungary. Three years prior to the liberalization -between 1998 and 2000- aggregate productivity grew at 5.8\% per year. The financial liberalization correlates with an acceleration in this growth. Within the three years after the reform (2002-2004), aggregate productivity grew at $9.6 \%$ per year and at $8.5 \%$ within the five years after it. Importantly, a structural test in the aggregate productivity trend confirms this result, even after controlling for other reforms such as the trade liberalization in 1996, the accession to the EU in 2004, and a falsification test for 1998 (Table A.24).

To understand the source of the increase in aggregate productivity growth and how it relates to the expansion in firms' productivity reported above, I follow a decomposition exercise in the spirit of Petrin and Levinsohn (2012). In particular, I break down aggregate productivity growth into a component related to changes in technical efficiency (TE) and a component aggregating the reallocation effects (RE). The technical efficiency component reflects the contribution of increases in firms' efficiency to growth, holding inputs constant. More precisely, this term is the sum of changes in a firm's RTFP weighted by the firm's share in total value added. The reallocation term arises from wedges between the input elasticities and input shares in production. As is well established

in the misallocation literature, in the presence of these wedges, reallocation of inputs across firms can affect aggregate RTFP (Restuccia and Rogerson 2008; Hsieh and Klenow 2009, among others). Formally, this term is the sum of the net gain in the allocation of inputs across firms weighted by the firm's share in value added. Hence, as in Petrin and Levinsohn (2012), aggregate RTFP growth can be expressed as

$$
\Delta R T F P_{t}=T E_{t}+R E_{t}=\sum_{i, t}^{N_{t}} D_{i t} \Delta R T F P_{i t}+\sum_{i, t}^{N_{t}} \sum_{i, z, t}^{Z_{t}} D_{i t}\left(\varepsilon_{i z t}-\theta_{i z t}\right) \Delta Z_{i z t},
$$

where $i$ and $t$ denote firm and year; $N_{t}$ denotes the total number of firms in the economy; $D_{i t}$ is the firm's share in total value added, where the weight is computed as the average between $t$ and $t-1 ; \triangle R T F P_{i t}$ is the firm's RTFP growth; $Z$ denotes inputs: capital and labor; $\varepsilon$ is the input elasticity; and $\theta$ is the input share in value added.

Panel A of Table 12 presents the average growth rate of aggregate RTFP and its components within the three years before and after the reform (1998-2000 and 2002-2004). Panel B reports the source of this growth. As shown in Panel A, prior to the liberalization, aggregate productivity growth was growing at $5.8 \%$ per year, from which $4.8 \%$ was explained by reallocation effects and only $1 \%$ by increases in within-firm productivity. Remarkably, this pattern of growth reversed after the financial liberalization. Following the reform, aggregate productivity accelerated to $9.6 \%$ 
per year; of this amount, within-firm productivity accounted for $7.9 \%$, and reallocation effects accounted for only $1.7 \%$. As a result, within-firm productivity turned to explain the bulk of the expansion in aggregate RTFP, which was $82 \%$ after the liberalization (Panel B). The rise in withinfirm productivity is explained mostly by the balanced panel of firms used above (column 4). ${ }^{33}$

What created these two opposite patterns of growth before and after the financial liberalization? Or, put differently, why did within-firm productivity grow at such a low pace before the reform and at such a high pace after it? The conjecture that emerges from this paper is that it is the change in all firms' incentives to invest in technology that raises within-firm productivity. In particular, according to the mechanism studied in this paper, distortions in the access to capital markets undermine competition and economy-wide innovation incentives. It is then natural that before the reform, within-firm productivity grew at a low pace. By reducing distortions in the access to international capital markets across firms, financial liberalization relaxes the financing terms of firms that were previously discriminated against and unchains the pro-competitive forces that led both discriminated and non-discriminated firms to invest more in technology. As all firms increase their productivity, within-firm productivity becomes a key driver of aggregate productivity growth.

\section{Conclusion}

The debate about the desirability of international financial flows is nowadays at the center of the discussion of researchers and policy makers. This paper focuses on one key aspect of capital controls: their impact on firms' access to capital markets and their consequences for competition and aggregate productivity growth.

Throughout the paper, I have shown that capital controls can create asymmetric access to external finance across firms, undermining market competition and economy-wide investment in technology. In developing economies with sufficiently developed financial systems, capital account openness can lead to economic growth. Capital inflows reduce asymmetric access to capital markets across firms, promoting market competition and a broad-based expansion in productivity growth. Firms that were previously policy discriminated invest more in technology because they face better financing terms. Non-discriminated firms also innovate more due to deeper competition.

This paper also sheds light on the current debate on capital controls. It is often argued that countries might consider it beneficial to encourage foreign direct investment and discourage financial flows. The evidence presented in this paper warns about possible distortions created by this policy. By restricting financial flows, capital controls can reduce local credit and tighten financing terms for domestic firms. This creates asymmetric access to external funds between domestic and

\footnotetext{
${ }^{33}$ This large increase in within-firm productivity is consistent with Bollard, Klenow, and Sharma (2013), who also find that the bulk of the increase in aggregate productivity in India following structural reforms is explained by the expansion of within-firm productivity.
} 
foreign firms, which reduces the competitive pressure of the former and allows foreign companies to obtain higher markups, resulting in lower investment and economic growth. Viewed through the lens of the paper, non-FDI flows might benefit the economy by reducing asymmetric access to capital markets across firms and increasing credit for domestic companies.

\section{REFERENCES}

Acemoglu, D. (2009): Introduction to Modern Economic Growth. Princeton University Press.

Acemoglu, D., P. Aghion, And F. Zilibotti (2006): "Distance to frontier, selection, and economic growth," Journal of the European Economic Association, 4(1), 37-74.

Acemoglu, D., And U. Akcigit (2011): "State-Dependent Intellectual Property Rights Policy," MIT Department of Economics Working Paper.

Aghion, P., N. Bloom, R. Blundell, R. Griffith, And P. Howitt (2005): "Competition and Innovation: An Inverted U Relationship," The Quarterly Journal of Economics, pp. 701-728.

Aghion, P., C. Harris, And J. Vickers (1997): "Competition and growth with step-by-step innovation: An example," European Economic Review, 41, 771-782.

Aghion, P., And P. Howitt (1992): "A Model of Growth through Creative Destruction," Econometrica, 60(2), $323-51$.

(2009): The Economics of Growth, vol. 1 of MIT Press Books. The MIT Press.

Atkeson, A., And A. Burstein (2008): "Pricing-to-Market, Trade Costs, and International Relative Prices," American Economic Review, 98(5), 1998-2031.

Atkeson, A., And A. T. Burstein (2010): "Innovation, Firm Dynamics, and International Trade," Journal of Political Economy, 118(3), 433-484.

Beck, T., A. Demirguc-Kunt, And R. Levine (2010): "Financial Institutions and Markets across Countries and over Time: The Updated Financial Development and Structure Database," The World Bank Economic Review 24, The World Bank.

Beck, T., R. Levine, AND N. LoAyza (2000): "Finance and the sources of growth," Journal of Financial Economics, 58(1-2), 261-300.

Bekaert, G., C. Harvey, And C. Lundblad (2011): "Financial Openness and Productivity," World Development, $39(1), 1-19$.

Benhabib, J., And M. M. Spiegel (2000): "The Role of Financial Development in Growth and Investment," Journal of Economic Growth, 5(4), 341-60.

Bertrand, M., E. Duflo, And S. Mullainathan (2004): "How Much Should We Trust Differences-in-Differences Estimates?," The Quarterly Journal of Economics, 119(1), 249-275.

Bloom, N., M. Schankerman, And J. Van Reenen (2013): "Identifying Technology Spillovers and Product Market Rivalry," Econometrica, 81(4), 1347-1393. 
Bollard, A., P. Klenow, AND G. Sharma (2013): "India's Mysterious Manufacturing Miracle," Review of Economic Dynamics, 16(1), 59-85.

Bonfiglioli, A. (2008): "Financial integration, productivity and capital accumulation," Journal of International Economics, 76(2), 337-355.

Bustos, P. (2011): "Trade Liberalization, Exports, and Technology Upgrading: Evidence on the Impact of MERCOSUR on Argentinian Firms," American Economic Review, 101(1), 304-40.

Chari, A., P. B. Henry, And D. SAsson (2012): "Capital Market Integration and Wages," American Economic Journal: Macroeconomics, 4(2), 102-32.

Coeurdacier, N., S. Guibaud, And K. Jin (2015): "Credit Constraints and Growth in a Global Economy," American Economic Review, 105(9), 2838-81.

De Loecker, J., AND F. Warzynski (2012): "Markups and Firm-Level Export Status," American Economic Review, 102(6), 2437-71.

Desai, M. A., C. F. Foley, And K. J. Forbes (2008): "Financial Constraints and Growth: Multinational and Local Firm Responses to Currency Depreciations," Review of Financial Studies, 21(6), 2857-2888.

Desai, M. A., C. F. Foley, And J. R. Hines (2006): "Capital Controls, Liberalizations, and Foreign Direct Investment," Review of Financial Studies, 19(4), 1433-1464.

Desai, M. R., C. F. Foley, And J. R. Hines (2004): “A Multinational Perspective on Capital Structure Choice and Internal Capital Markets," The Journal of Finance, 59(6), 2451-2487.

Devereux, M. B., AND K. M. Lee (2001): "Dynamic Gains from International Trade with Imperfect Competition and Market Power," Review of Development Economics, 5(2), 239-55.

Devereux, M. B., And J. Yetman (2014): "Capital Controls, Global Liquidity Traps, and the International Policy Trilemma," Scandinavian Journal of Economics, 116(1), 158-189.

Edmond, C., V. Midrigan, And D. Y. Xu (2015): "Competition, Markups, and the Gains from International Trade," American Economic Review, 105(10), 3183-3221.

FArhi, E., AND I. Werning (2012): "Dealing with the Trilemma: Optimal Capital Controls with Fixed Exchange Rates," NBER Working Papers 18199, National Bureau of Economic Research, Inc.

Forbes, K. J. (2007a): "One cost of the Chilean capital controls: Increased financial constraints for smaller traded firms," Journal of International Economics, 71(2), 294-323.

(2007b): "The Microeconomic Evidence on Capital Controls: No Free Lunch," in Capital Controls and Capital Flows in Emerging Economies: Policies, Practices and Consequences, NBER Chapters, pp. 171-202. National Bureau of Economic Research, Inc.

Foster, L., J. Haltiwanger, And C. Syverson (2008): "Reallocation, Firm Turnover, and Efficiency: Selection on Productivity or Profitability?," American Economic Review, 98(1), 394-425.

Gertler, M., AND K. Rogoff (1990): "North-South lending and endogenous domestic capital market inefficiencies," Journal of Monetary Economics, 26(2), 245-266.

Gopinath, G., S. Kalemli-Ozcan, L. Karabarbounis, And C. Villegas-Sanchez (2017): "Capital Allocation and Productivity in South Europe," The Quaterly Journal of Economics (forthcoming). 
Gorodnichenko, Y., And M. Schnitzer (2013): "Financial constraints and innovation: Why poor countries don't catch up," Journal of the European Economic Association, 11(5), 1115-1152.

Gourinchas, P.-O., And O. Jeanne (2006): "The Elusive Gains from International Financial Integration," Review of Economic Studies, 73(3), 715-741.

Grossman, G. M., And E. Helpman (1991): "Trade, knowledge spillovers, and growth," European Economic Review, 35(2-3), 517-526.

Heckman, J. J. (1974): "Shadow Prices, Market Wages, and Labor Supply," Econometrica, 42(4), 679-94.

(1979): "Sample Selection Bias as a Specification Error," Econometrica, 47(1), 153-61.

Holmes, T., AND J. Schmitz (2010): "Competition and productivity: a review of evidence," Annual Review of Economics, 2, 619-642.

Hsieh, C.-T., And P. Klenow (2009): "Misallocation and Manufacturing TFP in China and India," Quarterly Journal of Economics, 124(4), 1403-1448.

Ilyina, A., AND R. Samaniego (2011): "Technology and Financial Development," Journal of Money, Credit and Banking, 43(5), 899-921.

IMF (1998): "Hungary: Economic Policies for Sustainable Growth," Discussion paper, International Monetary Fund.

(2002): "Hungary: Financial System Stability Assessment Follow-up, including Reports on the Observamce of Standards and Codes on the following topics: Monetary and Financial Policy Transparency, Banking Supervision, Securities Regulation, Insurance Regulation and Payment Systems," IMF Country Report N02/112.

King, R. G., And R. Levine (1993a): "Finance and Growth: Schumpeter Might Be Right," The Quarterly Journal of Economics, 108(3), 717-37.

King, R. G., AND R. Levine (1993b): "Finance, entrepreneurship and growth: Theory and evidence," Journal of Monetary Economics, 32(3), 513-542.

Klette, T. J., AND S. Kortum (2004): "Innovating Firms and Aggregate Innovation," Journal of Political Economy, $112(5), 986-1018$.

Kose, A., E. Prasad, K. Rogoff, And S.-J. Wei (2008): "Financial Globalization: A Reappraisal," IMF Staff Papers, 56(1), 8-62.

Levchenko, A. A., R. Ranciere, And M. Thoenig (2009): "Growth and risk at the industry level: The real effects of financial liberalization," Journal of Development Economics, 89(2), 210-222.

Mendoza, E. G., V. Quadrini, And J.-V. Rios-Rull (2009): "Financial Integration, Financial Development, and Global Imbalances," Journal of Political Economy, 117(3), 371-416.

Midrigan, V., AND D. Y. Xu (2014): "Finance and Misallocation: Evidence from Plant-Level Data," American Economic Review, 104(2), 422-58.

NiCKell, S. (1996): "Competition and Corporate Performance," Journal of Political Economy, 104(4), 724-46.

Olley, G. S., AND A. PAKes (1996): "The Dynamics of Productivity in the Telecommunications Equipment Industry," Econometrica, 64(6), 1263-97.

Peters, M. (2013): "Heterogeneous Mark-Ups and Endogenous Misallocation," Mimeo. 
Petrin, A., And J. Levinsohn (2012): "Measuring aggregate productivity growth using plant-level data," The RAND Journal of Economics, 43(4), 705-725.

RADDATz, C. (2006): "Liquidity needs and vulnerability to financial underdevelopment," Journal of Financial Economics, 80(3), 677-722.

Rajan, R. G., And L. Zingales (1998): "Financial Dependence and Growth," American Economic Review, 88(3), 559-86.

Restuccia, D., And R. Rogerson (2008): "Policy Distortions and Aggregate Productivity with Heterogeneous Plants," Review of Economic Dynamics, 11(4), 707-720.

(2013): "Misallocation and productivity," Review of Economic Dynamics, 16(1), 1-10.

Schmitt-Grohé, S., And M. Uribe (2016): "Is Optimal Capital-Control Policy Countercyclical In Open-Economy Models With Collateral Constraints?," Working Paper 22481, National Bureau of Economic Research.

Smith, R. C., I. Walter, And G. DeLong (2012): Global Banking. Oxford University Press.

Stokey, N. L. (1995): "R\&D and Economic Growth," Review of Economic Studies, 62(3), 469-89.

Wooldridge, J. M. (2009): "On estimating firm-level production functions using proxy variables to control for unobservables," Economics Letters, 104(3), 112-114. 


\section{Figures AND TABLES}

RoW: Derivatives

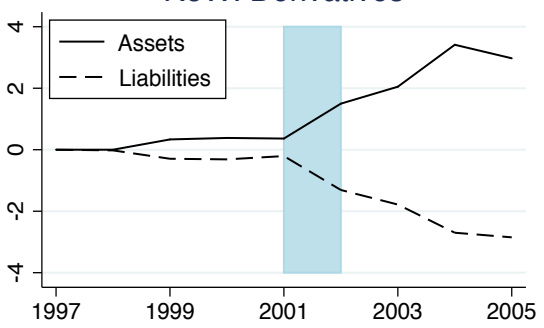

Banks: Net Capital Inflows

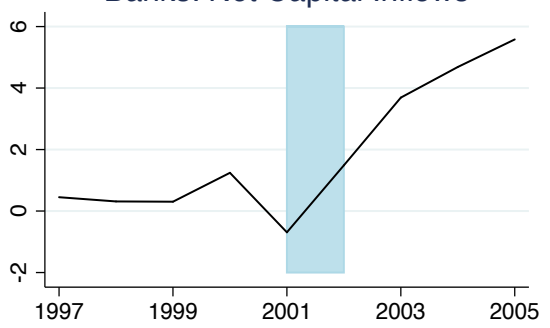

Local FX Market: Daily Turnover

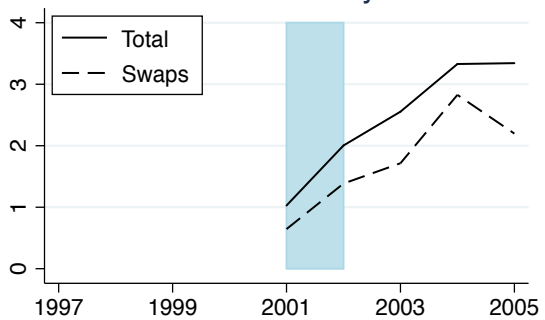

Banks: External Debt

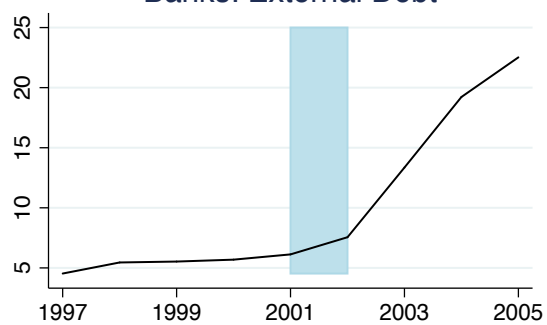

Note: In billions of US dollars. Source: NBH and IMF

Figure 1: International BorRowing of Financial Institutions

\section{Evolution Before and After the Reform}
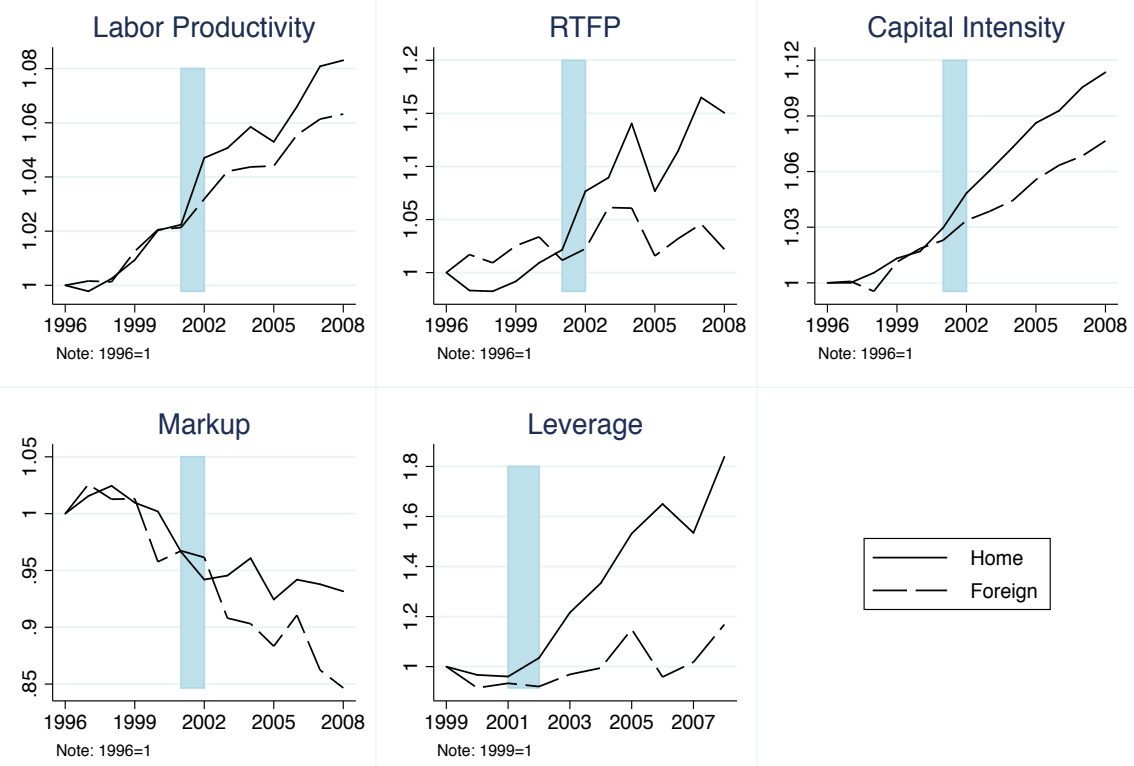

Figure 2: Evolution of Main Variables Before and After the Reform 


\section{Effect by Year}
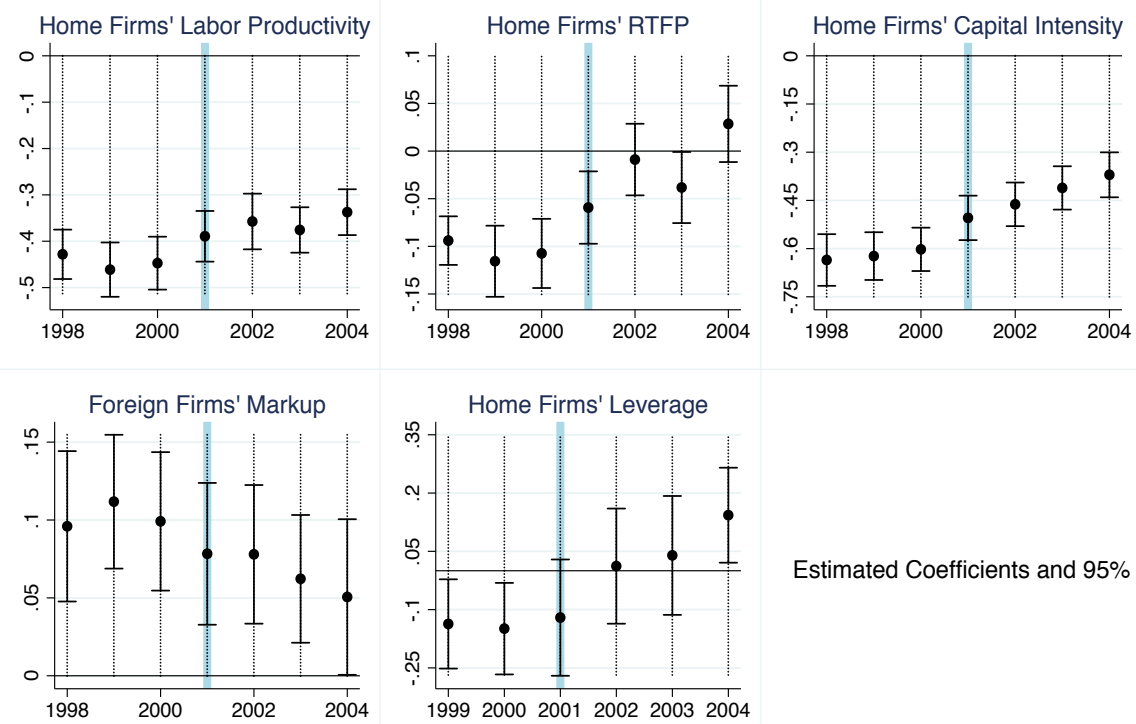

Estimated Coefficients and $95 \% \mathrm{Cl}$

Figure 3: EFfect By YeAR 
Table 1: Credit Market Before And After the Liberalization

\begin{tabular}{lll}
\hline \hline Aggregate Economy (in \%) & Before & After \\
\hline Credit-to-GDP ratio & 27 & 44 \\
Credit-to-deposit ratio & 83 & 113 \\
Lending interest rate & 12.8 & 7.5 \\
\hline Firms & & \\
\hline Credits to small and medium firms & 34 & 51 \\
Small and medium firms' debt in FX & 0 & 33 \\
Interest rate differential b. Home and Foreign & 3.2 & 0.65 \\
Differential in collateral b. Home and Foreign & 58 & 11 \\
\hline \hline
\end{tabular}

Notes: For rows 1-5, the source is National Bank of Hungary, and data correspond to December 2000 and December 2004. Rows 6-7 come from Business Environment and Enterprise Performance Surveys of the World Bank and the European Bank for Reconstruction and Development (surveys 2002 and 2005).

Table 2: Mean Characteristics of Home and Foreign Firms (1998): APEH Database

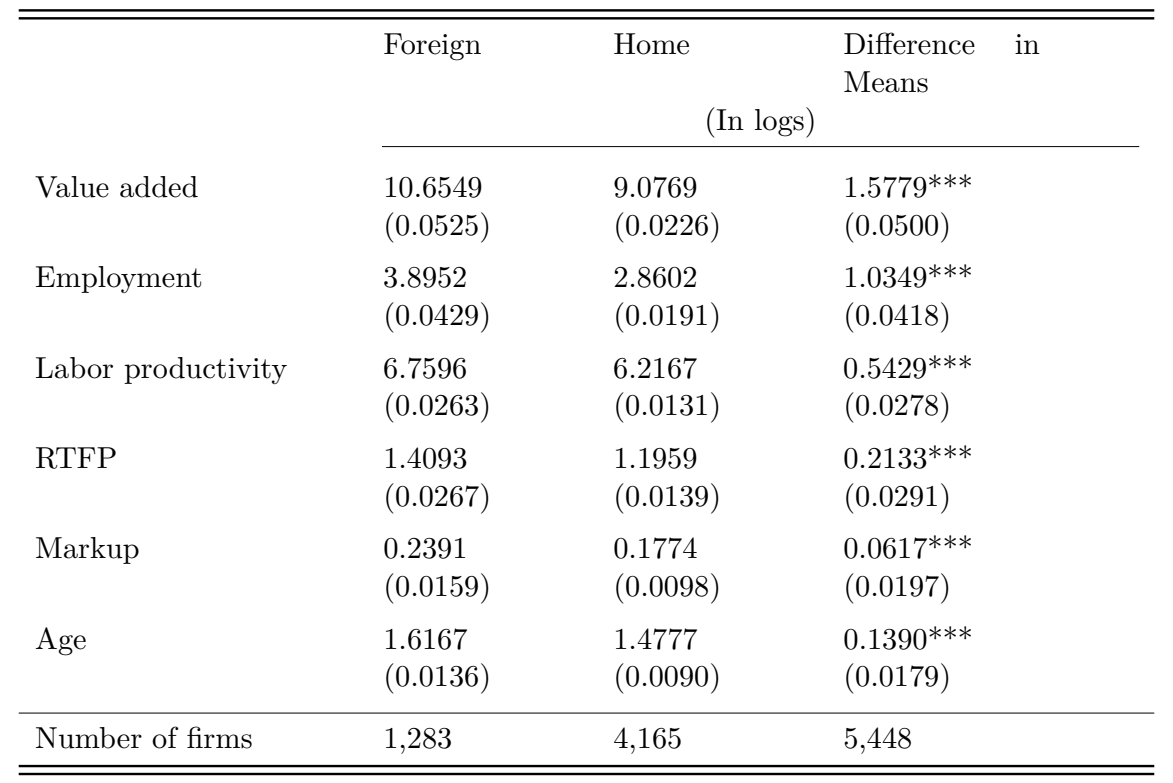

Notes: $*, * *, * * *$ significant at the 10,5 , and 1 percent level. Standard errors in parentheses. Source: APEH. 
Table 3: Mean Characteristics of Home and Foreign Firms (2001): BeEPS Database

\begin{tabular}{llll}
\hline \hline & Foreign & Home & $\begin{array}{l}\text { Difference in } \\
\text { Means }\end{array}$ \\
\cline { 2 - 4 } Probability of innovation & $\begin{array}{l}0.5946 \\
(0.0818)\end{array}$ & $\begin{array}{l}0.3521 \\
(0.0328)\end{array}$ & $\begin{array}{l}0.2425^{* * *} \\
(0.0858)\end{array}$ \\
Probability of R\&D & 0.3206 & 0.1675 & $0.1532^{* * *}$ \\
Interest rate paid & $(0.0647)$ & $(0.0267)$ & $(0.0614)$ \\
Required value of collateral & 9.0667 & 13.3198 & $-4.2531^{* * *}$ \\
& $(0.9200)$ & $(0.5845)$ & $(1.2687)$ \\
& $(124.2105$ & 185.2874 & $-61.0768^{* * *}$ \\
& $(13.7504)$ & $(11.5619)$ & $(25.6236)$ \\
\hline Number of firms & 53 & 197 & 250 \\
\hline \hline
\end{tabular}

Notes: $*, * *, * * *$ significant at the 10,5 , and 1 percent level. Standard errors in parentheses.

Source: BEEPS.

Table 4: Growth Rates Preceding the Reform

\begin{tabular}{llll}
\hline \hline Balanced Panel & Home & Foreign & Difference in Means \\
\hline Capital intensity & 0.0235 & 0.0289 & -0.0054 \\
& $(0.0032)$ & $(0.0040)$ & $(0.0061)$ \\
Labor productivity & 0.0554 & 0.0697 & -0.0143 \\
& $(0.0043)$ & $(0.0074)$ & $(0.0087)$ \\
RTFP & 0.0264 & 0.0395 & -0.0132 \\
& $(0.0041)$ & $(0.0071)$ & $(0.0082)$ \\
Markup & -0.0076 & 0.0058 & $-0.0133^{*}$ \\
& $(0.0040)$ & $(0.0068)$ & $(0.0080)$ \\
Leverage & -0.0077 & 0.0364 & -0.0441 \\
& $(0.0345)$ & $(0.0644)$ & $(0.0692)$ \\
$\mathrm{N}$ & 17,765 & 5,654 & 23,419 \\
\hline \hline
\end{tabular}

Notes: ${ }^{*}, * *, * * *$ significant at the 10,5 , and 1 percent level. Standard errors in parentheses. The table reports the mean of the variable growth rate within the five years prior to the reform (1996-2000). Source: APEH. 
Table 5: Investment in Capital and Productivity

\begin{tabular}{|c|c|c|c|c|c|c|c|c|c|}
\hline & \multicolumn{3}{|c|}{$\Delta$ Capital Intensity } & \multicolumn{3}{|c|}{$\Delta$ Labor Productivity } & \multicolumn{3}{|c|}{$\Delta \mathrm{RTFP}$} \\
\hline & (1) & $(2)$ & $(3)$ & (4) & (5) & (6) & (7) & (8) & (9) \\
\hline Home & $\begin{array}{l}0.239 * * * \\
(0.023)\end{array}$ & $\begin{array}{l}0.253^{* * *} \\
(0.025)\end{array}$ & $\begin{array}{l}0.252^{* * * *} \\
(0.025)\end{array}$ & $\begin{array}{l}0.074^{* * *} \\
(0.017)\end{array}$ & $\begin{array}{l}0.051^{* * *} \\
(0.017)\end{array}$ & $\begin{array}{l}0.053^{* * *} \\
(0.016)\end{array}$ & $\begin{array}{l}0.098^{* * *} \\
(0.015)\end{array}$ & $\begin{array}{l}0.032^{* *} \\
(0.014)\end{array}$ & $\begin{array}{l}0.032^{* *} \\
(0.016)\end{array}$ \\
\hline Firm-level controls & & yes & yes & & yes & yes & & yes & yes \\
\hline Local trends & & & yes & & & yes & & & yes \\
\hline Global trends & & & yes & & & yes & & & yes \\
\hline$R^{2}$ & 0.019 & 0.030 & 0.030 & 0.004 & 0.027 & 0.040 & 0.008 & 0.075 & 0.088 \\
\hline $\mathrm{N}$ & 5,448 & 5,448 & 5,448 & 5,448 & 5,448 & 5,448 & 5,448 & 5,448 & 5,448 \\
\hline
\end{tabular}

Notes: $*, * *, * * *$ significant at the 10,5 , and 1 percent level. Standard errors are clustered at four-digit NACE industries. All regressions include a constant term. Global industry controls include capital intensity and TFP growth rates of the four-digit NACE industries in the United States between 1998 and 2004. Local industry controls are capital intensity and RTFP average growth rates at the four-digit level in Hungary in the late 90s. Firm-level controls are age, employment and RTFP in the initial year (1998). Source: APEH.

Table 6: R\&D AND InNovation ACtivities

\begin{tabular}{|c|c|c|c|c|c|c|}
\hline & \multicolumn{3}{|c|}{ R\&D Activities } & \multicolumn{3}{|c|}{ Innovation Activities } \\
\hline & (1) & $(2)$ & $(3)$ & $(4)$ & $(5)$ & $(6)$ \\
\hline Home & $\begin{array}{l}-0.153^{* * *} \\
(0.028)\end{array}$ & $\begin{array}{l}-0.058 \\
(0.032)\end{array}$ & $\begin{array}{l}-0.032 \\
(0.030)\end{array}$ & $\begin{array}{l}-0.242^{\text {*** }} \\
(0.057)\end{array}$ & $\begin{array}{l}-0.158^{* *} \\
(0.054)\end{array}$ & $\begin{array}{l}-0.090 \\
(0.056)\end{array}$ \\
\hline Home*Reform & $\begin{array}{l}0.107^{*} \\
(0.048)\end{array}$ & $\begin{array}{l}0.083^{* *} \\
(0.033)\end{array}$ & $\begin{array}{l}0.090^{*} \\
(0.044)\end{array}$ & $\begin{array}{l}0.176^{* *} \\
(0.066)\end{array}$ & $\begin{array}{l}0.167^{* *} \\
(0.055)\end{array}$ & $\begin{array}{l}0.122^{*} \\
(0.056)\end{array}$ \\
\hline Reform & $\begin{array}{l}0.023 \\
(0.055)\end{array}$ & $\begin{array}{l}0.046 \\
(0.052)\end{array}$ & $\begin{array}{l}0.023 \\
(0.043)\end{array}$ & $\begin{array}{l}-0.084 \\
(0.063)\end{array}$ & $\begin{array}{l}-0.071 \\
(0.075)\end{array}$ & $\begin{array}{l}-0.099 \\
(0.081)\end{array}$ \\
\hline Firm-level controls & & yes & yes & & yes & yes \\
\hline Sector-fixed effects & & & yes & & & yes \\
\hline$R^{2}$ & 0.019 & 0.064 & 0.081 & 0.014 & 0.037 & 0.069 \\
\hline $\mathrm{N}$ & 774 & 774 & 774 & 774 & 774 & 774 \\
\hline
\end{tabular}

Notes: ${ }^{* * *}, * * *$ significant at the 10,5 , and 1 percent level. Standard errors are clustered at industry level. All regressions include a constant term. $R \& D$ is a dummy if the firm reports positive $R \& D$ expenditures. Innovation is a dummy if a firm reports any of the following activities: successfully developed a major product line, upgraded an existing product line, acquired a new production technology, obtained a new licensing agreement, and obtained a new quality accreditation. Firm-level controls are age and size. Source: BEEPS. 
Table 7: Financial Dependence: Investment in Capital and Productivity

\begin{tabular}{|c|c|c|c|c|c|c|c|c|c|}
\hline & \multicolumn{3}{|c|}{$\Delta$ Capital Intensity } & \multicolumn{3}{|c|}{$\Delta$ Labor Productivity } & \multicolumn{3}{|c|}{$\Delta \mathrm{RTFP}$} \\
\hline & $(1)$ & $(2)$ & (3) & $(4)$ & $(5)$ & (6) & (7) & $(8)$ & (9) \\
\hline Home & $\begin{array}{l}0.210^{* * *} \\
(0.021)\end{array}$ & $\begin{array}{l}0.221^{* * *} \\
(0.024)\end{array}$ & $\begin{array}{l}0.219^{* * *} \\
(0.024)\end{array}$ & $\begin{array}{l}0.058^{* * *} \\
(0.017)\end{array}$ & $\begin{array}{l}0.017 \\
(0.015)\end{array}$ & $\begin{array}{l}0.015 \\
(0.017)\end{array}$ & $\begin{array}{l}0.083^{* * *} \\
(0.018)\end{array}$ & $\begin{array}{l}-0.010 \\
(0.023)\end{array}$ & $\begin{array}{l}-0.016 \\
(0.023)\end{array}$ \\
\hline Home $*$ Fin. dep. & $\begin{array}{l}0.142^{*} \\
(0.080)\end{array}$ & $\begin{array}{l}0.156^{*} \\
(0.076)\end{array}$ & $\begin{array}{l}0.155^{*} \\
(0.077)\end{array}$ & $\begin{array}{l}0.093^{*} \\
(0.053)\end{array}$ & $\begin{array}{l}0.155^{* * *} \\
(0.045)\end{array}$ & $\begin{array}{l}0.147^{* * * *} \\
(0.046)\end{array}$ & $\begin{array}{l}0.087 \\
(0.072)\end{array}$ & $\begin{array}{l}0.181^{* *} \\
(0.080)\end{array}$ & $\begin{array}{l}0.167^{* *} \\
(0.067)\end{array}$ \\
\hline Fin. dep. & $\begin{array}{l}-0.084 \\
(0.064)\end{array}$ & $\begin{array}{l}-0.061 \\
(0.070)\end{array}$ & $\begin{array}{l}-0.053 \\
(0.077)\end{array}$ & $\begin{array}{l}0.276^{* *} \\
(0.124)\end{array}$ & $\begin{array}{l}0.320^{* *} \\
(0.124)\end{array}$ & $\begin{array}{l}0.334^{* *} \\
(0.134)\end{array}$ & $\begin{array}{l}0.162 \\
(0.107)\end{array}$ & $\begin{array}{l}0.222^{* *} \\
(0.10)\end{array}$ & $\begin{array}{l}0.277^{* * *} \\
(0.092)\end{array}$ \\
\hline Firm-level controls & & yes & yes & & yes & yes & & yes & yes \\
\hline Local trends & & & yes & & & yes & & & yes \\
\hline Global trends & & & yes & & & yes & & & yes \\
\hline$R^{2}$ & 0.020 & 0.031 & 0.031 & 0.034 & 0.074 & 0.081 & 0.022 & 0.111 & 0.120 \\
\hline $\mathrm{N}$ & 5,143 & 5,143 & 5,143 & 5,143 & 5,143 & 5,143 & 5,143 & 5,143 & 5,143 \\
\hline
\end{tabular}

Notes: ${ }^{*},{ }^{* *},{ }^{* * *}$ significant at the 10,5 , and 1 percent level. Standard errors are clustered at four-digit NACE industries. All regressions include a constant term. Financial Dependence is the Rajan and Zingales' (1998) index. Global industry controls include capital intensity and TFP growth rates of the four-digit NACE industries in the United States between 1998 and 2004. Local industry controls are capital intensity and RTFP average growth rates at the four-digit level in Hungary in the late 90s. Firm-level controls are age, employment and RTFP in the initial year (1998). Source: APEH.

Table 8: FinANCing TERMS

\begin{tabular}{|c|c|c|c|c|c|c|}
\hline & \multicolumn{3}{|c|}{ Interest Rate } & \multicolumn{3}{|c|}{ Value of Collateral } \\
\hline & (1) & $(2)$ & $(3)$ & $(4)$ & $(5)$ & $(6)$ \\
\hline Home & $\begin{array}{l}4.253^{* * *} \\
(1.132)\end{array}$ & $\begin{array}{l}3.707^{* * * *} \\
(1.027)\end{array}$ & $\begin{array}{l}3.729 * * * \\
(1.051)\end{array}$ & $\begin{array}{l}60.789^{* * *} \\
(15.391)\end{array}$ & $\begin{array}{l}49.174^{* *} \\
(15.727)\end{array}$ & $\begin{array}{l}52.106^{* * *} \\
(11.263)\end{array}$ \\
\hline Home*Reform & $\begin{array}{l}-3.879^{* *} \\
(1.134)\end{array}$ & $\begin{array}{l}-3.858^{* * *} \\
(1.018)\end{array}$ & $\begin{array}{l}-3.947^{* * *} \\
(1.076)\end{array}$ & $\begin{array}{c}-37.653^{*} \\
(17.130)\end{array}$ & $\begin{array}{c}-35.438^{*} \\
(17.104)\end{array}$ & $\begin{array}{c}-31.170^{* *} \\
(10.911)\end{array}$ \\
\hline Reform & $\begin{array}{l}-0.026 \\
(0.951)\end{array}$ & $\begin{array}{l}-0.159 \\
(0.830)\end{array}$ & $\begin{array}{l}-0.221 \\
(0.890)\end{array}$ & $\begin{array}{l}20.968 \\
(12.571)\end{array}$ & $\begin{array}{l}19.574 \\
(13.192)\end{array}$ & $\begin{array}{l}13.368 \\
(11.635)\end{array}$ \\
\hline Firm-level controls & & yes & yes & & yes & yes \\
\hline Sector- fixed effects & & & yes & & & yes \\
\hline$R^{2}$ & 0.175 & 0.202 & 0.217 & 0.035 & 0.045 & 0.103 \\
\hline $\mathrm{N}$ & 415 & 415 & 415 & 399 & 399 & 399 \\
\hline
\end{tabular}

Notes: ${ }^{*},{ }^{*}, * * *$ significant at the 10,5 , and 1 percent level. Standard errors are clustered at industry level. All regressions include a constant term. Firm-level controls are age and size. Source: BEEPS. 
Table 9: Leverage

\begin{tabular}{lllll}
\hline \hline & \multicolumn{3}{c}{$\Delta$ Leverage } \\
\cline { 2 - 5 } & $(1)$ & $(2)$ & $(3)$ & $(4)$ \\
\hline Home & $0.160^{* *}$ & $0.239^{* * *}$ & $0.230^{* * *}$ & $0.238^{* *}$ \\
& $(0.073)$ & $(0.085)$ & $(0.088)$ & $(0.100)$ \\
Home* Fin. dep. & & & $0.526^{* *}$ \\
& & & $(0.266)$ \\
Financial dependence & & & & $-0.595^{* *}$ \\
& & & & $(0.234)$ \\
Firm-level controls & & yes & yes & yes \\
Local trends & & & yes & yes \\
Global trends & & & yes & yes \\
$R^{2}$ & 0.002 & 0.006 & 0.007 & 0.015 \\
$\mathrm{~N}$ & 2,742 & 2,742 & 2,742 & 2,742 \\
\hline \hline Notes: & & & & \\
\hline
\end{tabular}

Notes: ${ }^{* * *},{ }^{* *}$ significant at the 10,5 , and 1 percent level. Standard errors are clustered at fourdigit NACE industries. All regressions include a constant term. Financial dependence is the Rajan and Zingales (1998) index. Global industry controls include capital intensity and TFP growth rates of the four-digit NACE industries in the United States between 1998 and 2004. Local industry controls are capital intensity and RTFP average growth rates at the four-digit level in Hungary in the late 90s. Firm-level controls are age, employment and RTFP in the initial year (1998). Source: APEH.

Table 10: Foreign Firms' Markups

\begin{tabular}{lllll}
\hline \hline & \multicolumn{4}{c}{$\Delta$ Markups } \\
\cline { 2 - 5 } & $(1)$ & $(2)$ & $(3)$ & $(4)$ \\
\hline Foreign & $-0.017^{*}$ & $-0.025^{* *}$ & $-0.026^{* *}$ & $0.030^{*}$ \\
& $(0.009)$ & $(0.011)$ & $(0.012)$ & $(0.016)$ \\
Foreign*Fin. dep. & & & & $-0.205^{* * *}$ \\
& & & & $(0.043)$ \\
Financial dependence & & & & $0.212^{* * *}$ \\
& & & & $(0.069)$ \\
Firm-level control & & yes & yes & yes \\
Local trend & & & yes & yes \\
Global trends & & & yes & yes \\
$R^{2}$ & 0.000 & 0.023 & 0.024 & 0.057 \\
$\mathrm{~N}$ & 5,376 & 5,376 & 5,376 & 5,086 \\
\hline \hline
\end{tabular}

Notes: $*, * *, * * *$ significant at the 10,5 , and 1 percent level. Standard errors are clustered at four-digit NACE industries. All regressions include a constant term. Financial dependence is the Rajan and Zingales (1998) index. Global industry controls include capital intensity and TFP growth rates of the four-digit NACE industries in the United States between 1998 and 2004. Local industry controls are capital intensity and RTFP average growth rates at the four-digit level in Hungary in the late 90s. Firm-level controls are age, employment and RTFP in the initial year (1998). Source: APEH. 
Table 11: Markup and RTFP Dispersions and Industry Concentration

\begin{tabular}{|c|c|c|c|c|c|c|c|c|c|}
\hline & \multicolumn{3}{|c|}{ Change in RTFP Dispersion } & \multicolumn{3}{|c|}{ Change in Markup Dispersion } & \multicolumn{3}{|c|}{ Change in Concentration } \\
\hline & Late $90 \mathrm{~s}$ & Reform & $\begin{array}{l}\text { Accounting for } \\
\text { Pre- } \\
\text { trends }\end{array}$ & Late $90 \mathrm{~s}$ & Reform & $\begin{array}{l}\text { Accounting for } \\
\text { Pre- } \\
\text { trends }\end{array}$ & Late $90 \mathrm{~s}$ & Reform & $\begin{array}{l}\text { Accounting for } \\
\text { Pre- } \\
\text { trends }\end{array}$ \\
\hline & (1) & $(2)$ & (3) & (4) & (5) & (6) & (7) & (8) & (9) \\
\hline Initial value & $\begin{array}{l}-0.076 \\
(0.064)\end{array}$ & $\begin{array}{l}-0.202^{* *} \\
(0.079)\end{array}$ & $\begin{array}{l}-0.076 \\
(0.077)\end{array}$ & $\begin{array}{l}-0.419 * * * \\
(0.063)\end{array}$ & $\begin{array}{l}-0.730^{* * *} \\
(0.135)\end{array}$ & $\begin{array}{l}-0.419 * * * \\
(0.079)\end{array}$ & $\begin{array}{l}-0.177^{* * *} \\
(0.075)\end{array}$ & $\begin{array}{l}-0.317^{* * *} \\
(0.085)\end{array}$ & $\begin{array}{l}-0.177^{* * *} \\
(0.060)\end{array}$ \\
\hline Initial value*T & & & $\begin{array}{l}-0.222^{* *} \\
(0.107)\end{array}$ & & & $\begin{array}{l}-0.310^{* *} \\
(0.140)\end{array}$ & & & $\begin{array}{l}-0.245^{* * *} \\
(0.091)\end{array}$ \\
\hline $\mathrm{T}$ & & & $\begin{array}{l}0.186 \\
(0.128)\end{array}$ & & & $\begin{array}{l}0.134^{* *} \\
(0.054)\end{array}$ & & & $\begin{array}{l}0.211^{* * *} \\
(0.072)\end{array}$ \\
\hline$R^{2}$ & 0.018 & 0.074 & 0.100 & 0.354 & 0.280 & 0.325 & 0.101 & 0.145 & 0.223 \\
\hline $\mathrm{N}$ & 82 & 82 & 164 & 78 & 78 & 156 & 82 & 82 & 164 \\
\hline
\end{tabular}

Notes: All regressions include a constant term. ${ }^{*},{ }^{* *},{ }^{* * *}$ significant at the 10, 5 , and 1 percent level. Standard errors in parentheses. Three-digit NACE industries correlations. Source: APEH.

Table 12: Contribution to Aggregate RTFP Growth

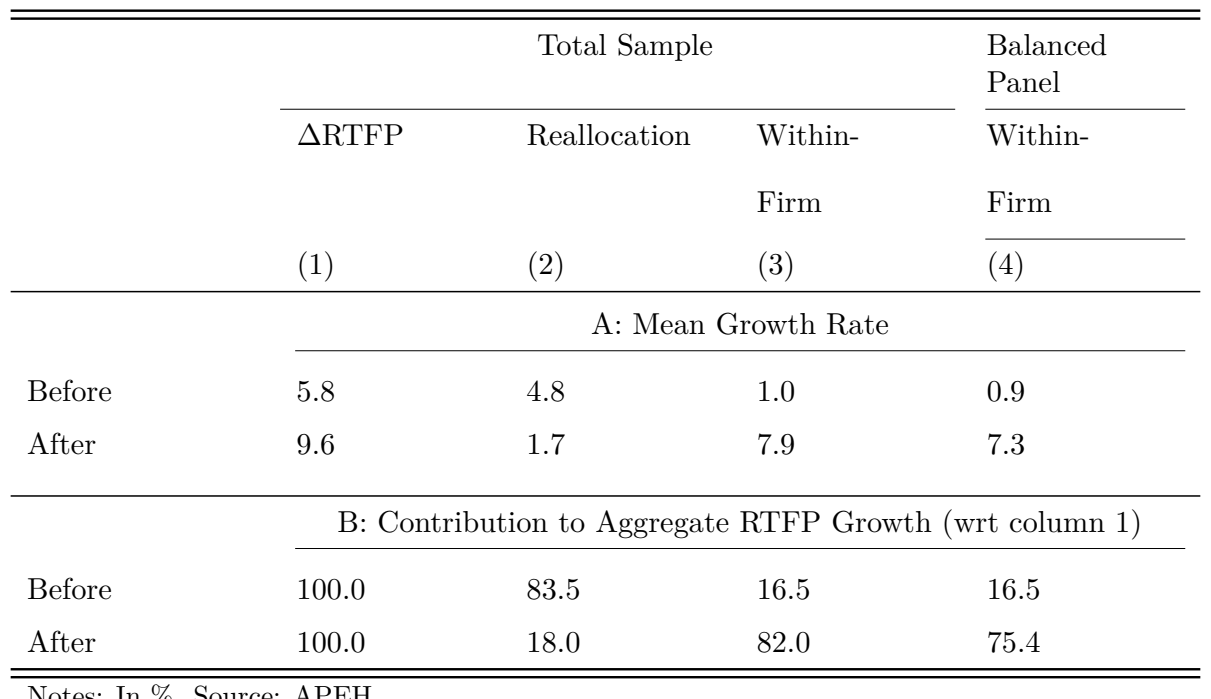

Notes: In \%. Source: APEH. 


\section{Additional Figures, Robustness Tests,}

\section{and Model's Additional Derivations}

and Extensions

(Not for publication) 


\section{Appendix A Additional Figures}
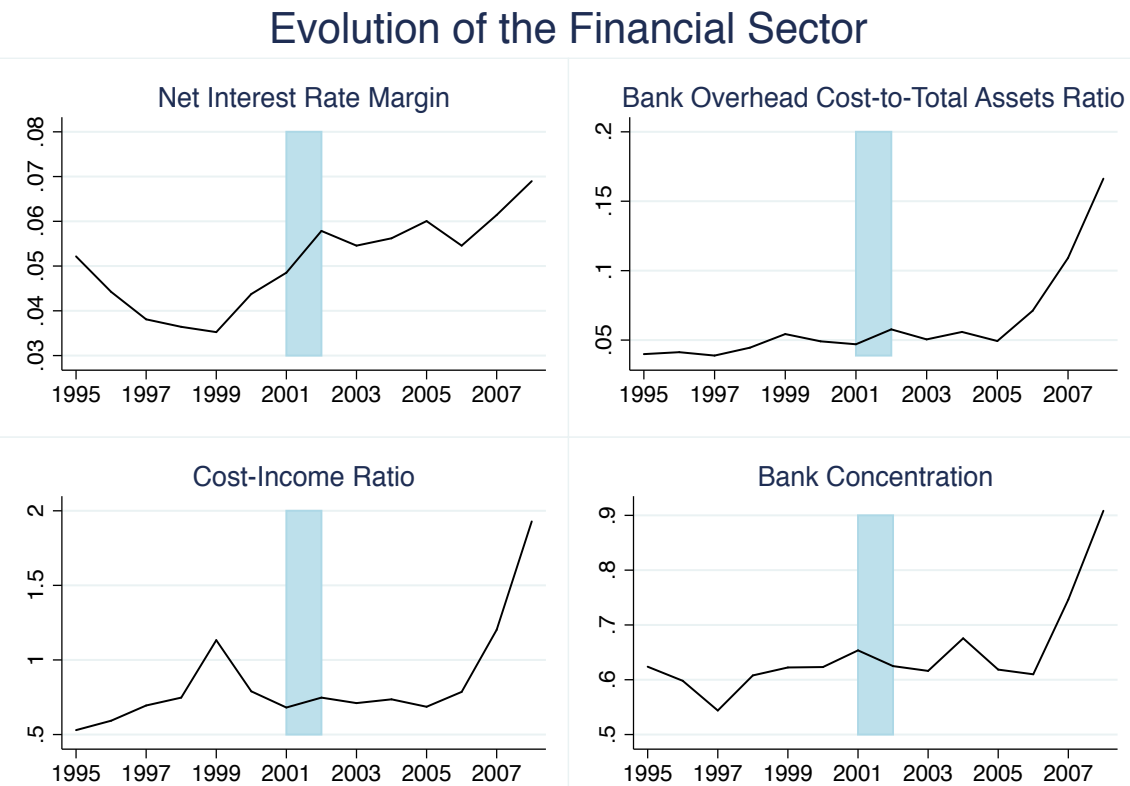

Note: In \%. Source: Beck and Demirguc-Kunt (2009)

Figure A.1: Evolution of the Financial Sector in Hungary

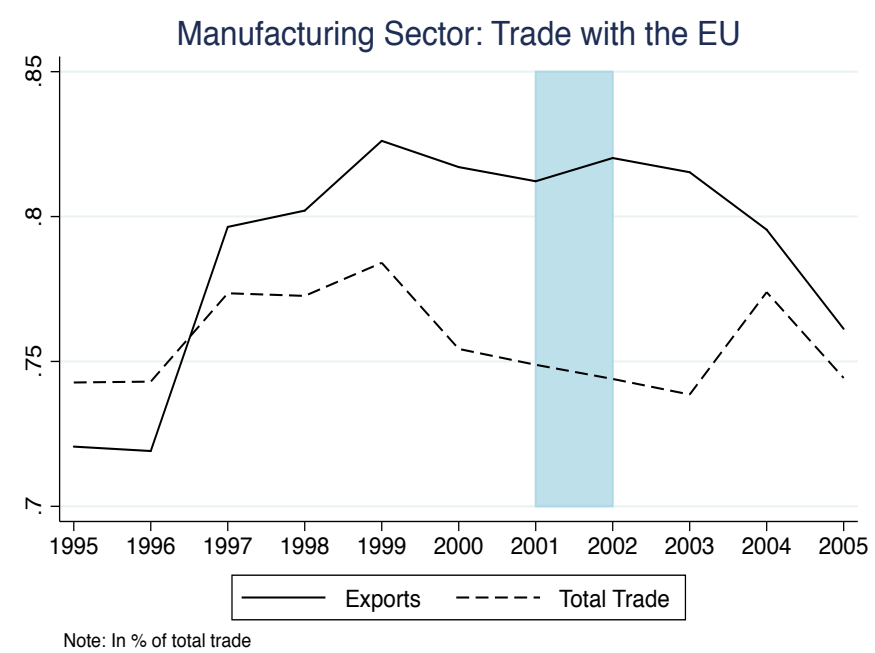

Figure A.2: Hungary: trade and exports With the European Union 

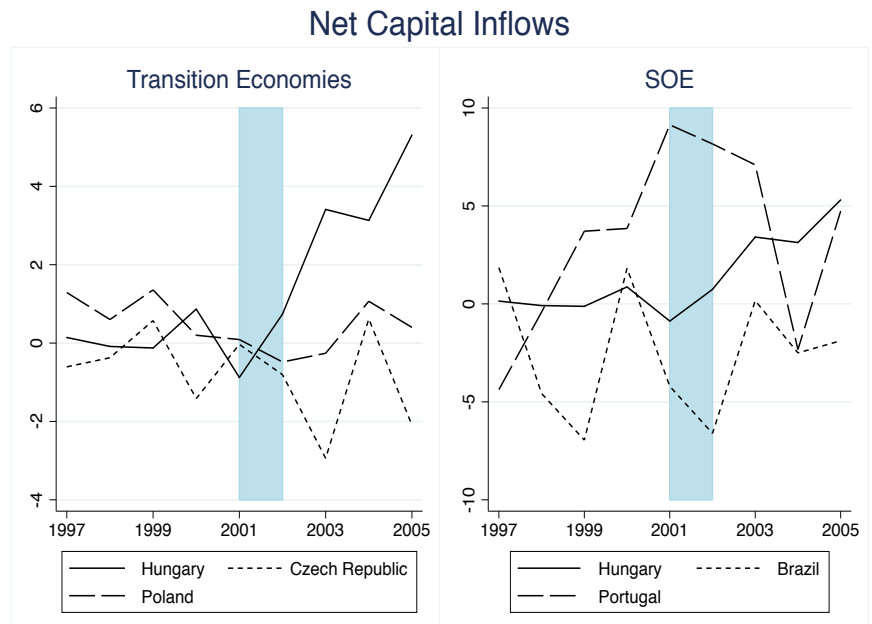

Note: In billions US dollars. Source: IMF

Figure A.3: Net Capital Inflows to Transition and Small Open Economies

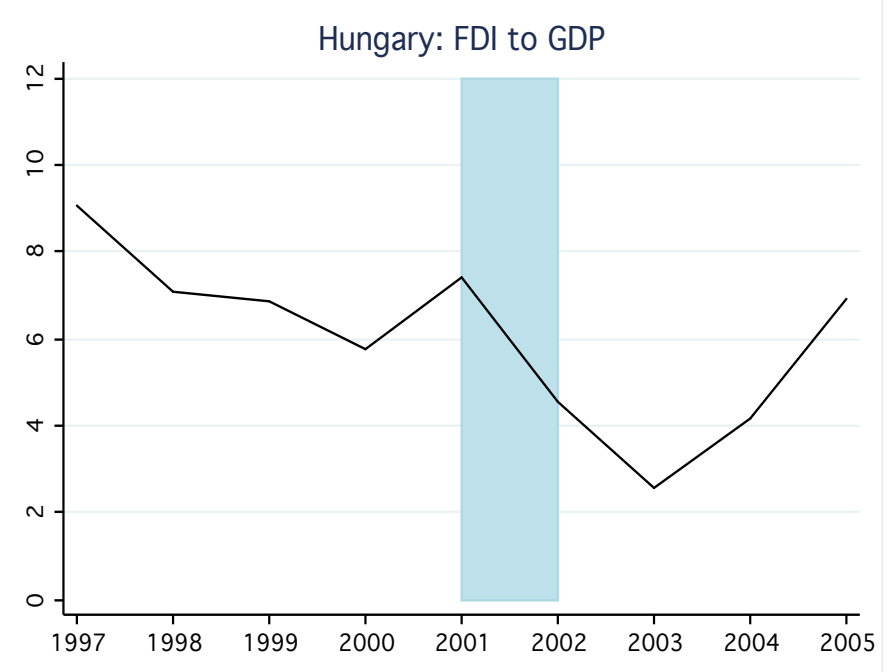

Figure A.4: Evolution of Foreign Direct Investment in Hungary 


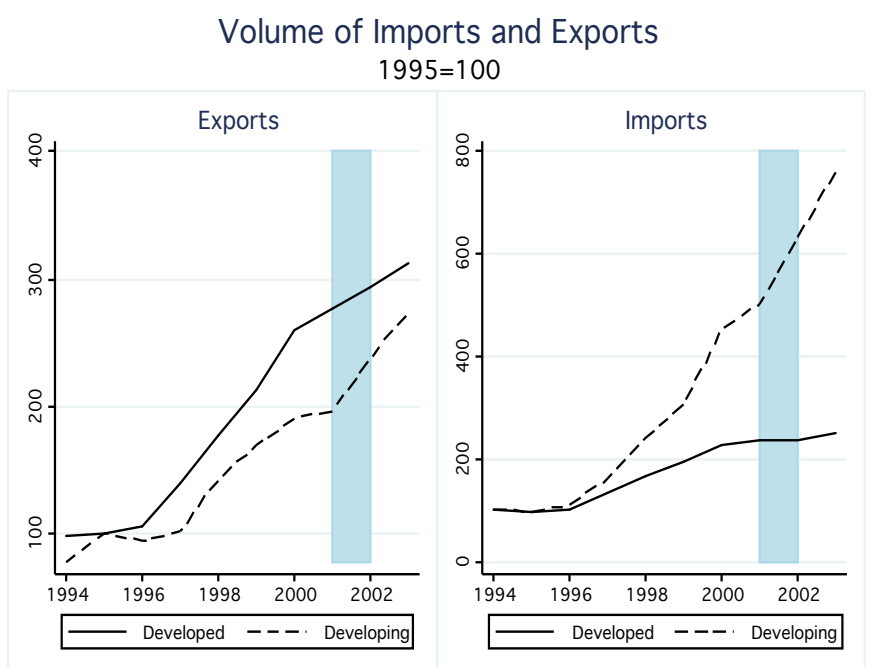

Figure A.5: Evolution of Trade in Hungary 


\section{Additional Tables: Robustness Tests}

Table A.1: Firm Survival Ratio

\begin{tabular}{llll}
\hline \hline & \multicolumn{3}{c}{ Firm Survival } \\
\cline { 2 - 4 } & Home & Foreign & $\begin{array}{l}\text { Difference } \\
\text { Means }\end{array}$ \\
\hline Survival ratio & $\begin{array}{l}0.8672 \\
(0.0026)\end{array}$ & $\begin{array}{l}0.8579 \\
(0.0060)\end{array}$ & $\begin{array}{l}0.0092 \\
(0.0064)\end{array}$ \\
$\mathrm{N}$ & 16,826 & 3,323 & 20,149 \\
\hline \hline $\begin{array}{l}\text { Notes: }{ }^{*},{ }^{* *},{ }^{* * *} \text { significant at the 10, } 5, \text { and 1 percent level. Standard errors in parentheses. The table } \\
\text { reports the mean of a dummy variable on surviving after the reform. In particular, for all existing firms } \\
\text { prior to the reform (in 2000), surviving = 1 if the firm did not exit within the three years following the } \\
\text { reform }(2002-2004), \text { and } 0 \text { otherwise. Source: APEH. }\end{array}$
\end{tabular}

Table A.2: Number OF Banks in Hungary

\begin{tabular}{llllllllllll}
\hline \hline & 1995 & 1996 & 1997 & 1998 & 1999 & 2000 & 2001 & 2002 & 2003 & 2004 & 2005 \\
\hline Number of banks & 43 & 43 & 43 & 45 & 45 & 45 & 45 & 44 & 44 & 44 & 44 \\
\hline \hline
\end{tabular}




\section{Table A.3: Robustness Test: Investment in Capital and Productivity}

\begin{tabular}{|c|c|c|c|c|c|}
\hline & \multicolumn{5}{|c|}{$\Delta$ Capital Intensity } \\
\hline & (1) & $(2)$ & (3) & (4) & (5) \\
\hline Home & $\begin{array}{l}0.249^{* * *} \\
(0.026)\end{array}$ & $\begin{array}{l}0.171^{* * *} \\
(0.031)\end{array}$ & $\begin{array}{l}0.254^{* * *} \\
(0.027)\end{array}$ & $\begin{array}{l}0.241 * * * \\
(0.026)\end{array}$ & $\begin{array}{l}0.282^{* * *} \\
(0.026)\end{array}$ \\
\hline Firm-level controls & yes & yes & yes & yes & yes \\
\hline Sector-fixed effects & yes & & & & \\
\hline Local trends & & yes & yes & yes & yes \\
\hline Global trends & & yes & yes & yes & yes \\
\hline$R^{2}$ & 0.060 & 0.019 & 0.029 & 0.029 & 0.031 \\
\hline \multirow[t]{3}{*}{$\mathrm{N}$} & 5,448 & 4,747 & 4,950 & 4,881 & 5,158 \\
\hline & \multicolumn{5}{|c|}{$\Delta$ Labor Productivity } \\
\hline & (1) & $(2)$ & (3) & (4) & (5) \\
\hline Home & $\begin{array}{l}0.046^{* * *} \\
(0.015)\end{array}$ & $\begin{array}{l}0.070^{* * *} \\
(0.020)\end{array}$ & $\begin{array}{l}0.052^{* * *} \\
(0.018)\end{array}$ & $\begin{array}{l}0.061 * * * \\
(0.016)\end{array}$ & $\begin{array}{l}0.060^{* * *} \\
(0.017)\end{array}$ \\
\hline Firm-level controls & yes & yes & yes & yes & yes \\
\hline Sector-fixed effects & yes & & & & \\
\hline Local trends & & yes & yes & yes & yes \\
\hline Global trends & & yes & yes & yes & yes \\
\hline$R^{2}$ & 0.235 & 0.040 & 0.039 & 0.029 & 0.040 \\
\hline \multirow[t]{3}{*}{$\mathrm{N}$} & 5,448 & 4,747 & 4,950 & 4,881 & 5,158 \\
\hline & \multicolumn{5}{|c|}{$\Delta \mathrm{RTFP}$} \\
\hline & (1) & $(2)$ & (3) & (4) & (5) \\
\hline Home & $\begin{array}{l}0.032^{*} \\
(0.016)\end{array}$ & $\begin{array}{l}0.057^{* * *} \\
(0.020)\end{array}$ & $\begin{array}{l}0.031^{*} \\
(0.018)\end{array}$ & $\begin{array}{l}0.039^{* *} \\
(0.017)\end{array}$ & $\begin{array}{l}0.039 * * \\
(0.018)\end{array}$ \\
\hline Firm-level controls & yes & yes & yes & yes & yes \\
\hline Sector-fixed effects & yes & & & & \\
\hline Local trends & & yes & yes & yes & yes \\
\hline Global trends & & yes & yes & yes & yes \\
\hline$R^{2}$ & 0.155 & 0.088 & 0.086 & 0.077 & 0.087 \\
\hline $\mathrm{N}$ & 5,448 & 4,747 & 4,950 & 4,881 & 5,158 \\
\hline
\end{tabular}

Notes: $*, * *, * * *$ significant at the 10,5 , and 1 percent level. Standard errors are clustered at four-digit NACE industries. All regressions include a constant term. Global industry controls include capital intensity and TFP growth rates of the four-digit NACE industries in the United States between 1998 and 2004. Local industry controls are capital intensity and TFP average growth rates at the four-digit level in Hungary in the late 90s. Firm-level controls are age, employment and RTFP in the initial year (1998). Column 1 controls for four-digit industry fixed effects. Column 2 removes those foreign firms whose foreign shares exceed more than $75 \%$ of total shares on average between 1998 and 2000. Column 3 restricts the analysis to foreign firms that are not used as export platforms (more than $75 \%$ of exports). Column 4 removes the top 1 percentile of firms (in value added). Column 5 controls for firms that change the ownership status between the pre- and post-reform periods. Source: APEH. 
Table A.4: Credit Market Before the Liberalization: Home Firms

\begin{tabular}{llll}
\hline \hline & Exporters & Non-Exporters & $\begin{array}{l}\text { Difference in } \\
\text { Means }\end{array}$ \\
\cline { 2 - 4 } Paid interest rate & 13.3250 & 13.2015 & 0.1234 \\
& $(1.5917)$ & $(0.6585)$ & $(1.5478)$ \\
Required collateral & 4.8618 & 5.0060 & -0.1441 \\
Leverage & $(0.1301)$ & $(0.0479)$ & $(0.1134)$ \\
& 0.0952 & 0.0977 & 0.0025 \\
& $(0.0058)$ & $(0.0054)$ & $(0.0086)$ \\
\hline \hline
\end{tabular}

Notes: ${ }^{*}, * * * * *$ significant at the 10,5 , and 1 percent level. Standard errors in parentheses. Rows 1 and 2 come from Business Environment and Enterprise Performance Surveys of the World Bank and the European Bank for Reconstruction and Development, for the years 2001 and 2004. Row 3 uses APEH data. The debt-to-sales ratio is computed using short-term debt over sales. Row 2 is in logs.

Table A.5: Investment in Capital and Productivity: Home Exporters vi. NON-EXPORTERS

\begin{tabular}{|c|c|c|c|}
\hline & $\Delta$ Capital Intensity & $\Delta$ Labor Productivity & $\Delta \mathrm{RTFP}$ \\
\hline & $(1)$ & $(2)$ & $(3)$ \\
\hline Home & $\begin{array}{l}0.255^{* * *} \\
(0.027)\end{array}$ & $\begin{array}{l}0.060 * * * \\
(0.019)\end{array}$ & $\begin{array}{l}0.034^{*} \\
(0.018)\end{array}$ \\
\hline Home*Exporter & $\begin{array}{l}-0.012 \\
(0.025)\end{array}$ & $\begin{array}{l}-0.023 \\
(0.025)\end{array}$ & $\begin{array}{c}-0.004 \\
(0.020)\end{array}$ \\
\hline Firm controls & yes & yes & yes \\
\hline Local trends & yes & yes & yes \\
\hline Global trends & yes & yes & yes \\
\hline$R^{2}$ & 0.030 & 0.041 & 0.088 \\
\hline $\mathrm{N}$ & 5,448 & 5,448 & 5,448 \\
\hline
\end{tabular}

Notes: $*, * *, * *$ significant at the 10,5 , and 1 percent level. Standard errors are clustered at four-digit NACE industries. All regressions include a constant term. Exporter is defined as having an average export share larger than 0.05 between 1998 and 2000. Global industry controls include capital intensity and TFP growth rates of the four-digit NACE industries in the United States between 1998 and 2004. Local industry controls are capital intensity and RTFP average growth rates at the four-digit level in Hungary in the late 90s. Firm-level controls are age, employment and RTFP in the initial year (1998). Source: APEH. 
Table A.6: Robustness Test: RTFP And Markups

\begin{tabular}{|c|c|c|c|c|c|}
\hline & \multicolumn{2}{|c|}{$\Delta \mathrm{RTFP}$} & \multicolumn{3}{|c|}{$\Delta$ Markups } \\
\hline & $\begin{array}{l}\text { WLP } \\
(1)\end{array}$ & $\begin{array}{l}\text { DLTL } \\
(2)\end{array}$ & $\begin{array}{l}\text { PCM } \\
(3)\end{array}$ & $\begin{array}{l}\text { WLP } \\
(4)\end{array}$ & $\begin{array}{l}\text { DLTL } \\
(5)\end{array}$ \\
\hline Home & $\begin{array}{l}0.028^{* * *} \\
(0.009)\end{array}$ & $\begin{array}{l}0.081^{* * *} \\
(0.026)\end{array}$ & & & \\
\hline Foreign & & & $\begin{array}{l}-0.127^{* *} \\
(0.051)\end{array}$ & $\begin{array}{l}-0.034^{* * *} \\
(0.011)\end{array}$ & $\begin{array}{l}-0.024^{*} \\
(0.013)\end{array}$ \\
\hline Firm-level controls & yes & yes & yes & yes & yes \\
\hline Local trends & yes & yes & yes & yes & yes \\
\hline Global trends & yes & yes & yes & yes & yes \\
\hline$R^{2}$ & 0.034 & 0.065 & 0.006 & 0.028 & 0.019 \\
\hline $\mathrm{N}$ & 4,864 & 4,839 & 5,029 & 4,864 & 4,839 \\
\hline
\end{tabular}

Notes: ${ }^{*}, * * * * *$ significant at the 10,5 , and 1 percent level. Standard errors are clustered at four-digit NACE industries. All regressions include a constant term. Global industry controls include capital intensity and TFP growth rates of the four-digit NACE industries in the United States between 1998 and 2004. Local industry controls are capital intensity and TFP growth rates at the four-digit level in Hungary in the late 90s. Firmlevel controls are age, employment and RTFP in the initial year (1998). Column 1 reports the RTFP measure with the coefficients of the production function estimated following Wooldridge (2009) and Petrin and Levinsohn (2012) methodology. Column 2 reports the RTFP of the translog production function using the De Loecker and Warzynski (2012) methodology to estimate the elasticities of the factor of production. Column 3 reports the price-cost margin estimated as in Aghion, Bloom, Blundell, Griffith, and Howitt (2005). Column 4 and 5 present the markup estimated using the elasticities computed for columns 1 and 2, and following equation (13). Source: APEH.

Table A.7: Robustness Tests: Subsidies And Exceptions II

\begin{tabular}{|c|c|c|c|c|c|c|c|c|}
\hline & \multicolumn{2}{|c|}{$\Delta$ Capital Intensity } & \multicolumn{2}{|c|}{$\Delta$ Labor Productivity } & \multicolumn{2}{|c|}{$\Delta$ RTFP } & \multicolumn{2}{|c|}{$\Delta$ Leverage } \\
\hline & (1) & (2) & (3) & (4) & (5) & (6) & (7) & (8) \\
\hline Home & $\begin{array}{l}0.254^{* * *} \\
(0.025)\end{array}$ & $\begin{array}{l}0.224^{* * *} \\
(0.023)\end{array}$ & $\begin{array}{l}0.054^{* * *} \\
(0.016)\end{array}$ & $\begin{array}{l}0.018 \\
(0.016)\end{array}$ & $\begin{array}{l}0.034^{* *} \\
(0.016)\end{array}$ & $\begin{array}{l}-0.014 \\
(0.023)\end{array}$ & $\begin{array}{l}0.233^{* * *} \\
(0.088)\end{array}$ & $\begin{array}{l}0.239^{* *} \\
(0.100)\end{array}$ \\
\hline Home* Fin. dep. & & $\begin{array}{l}0.146^{*} \\
(0.077)\end{array}$ & & $\begin{array}{l}0.142^{\text {*** }} \\
(0.047)\end{array}$ & & $\begin{array}{l}0.164^{* *} \\
(0.068)\end{array}$ & & $\begin{array}{l}0.526^{* *} \\
(0.266)\end{array}$ \\
\hline Fin. dep. & & $\begin{array}{l}-0.045 \\
(0.078)\end{array}$ & & $\begin{array}{l}0.339^{* *} \\
(0.133)\end{array}$ & & $\begin{array}{l}0.279^{* * *} \\
(0.092)\end{array}$ & & $\begin{array}{l}-0.594^{* *} \\
(0.234)\end{array}$ \\
\hline Subsidy and tax ex. & $\begin{array}{l}-0.313^{* *} \\
(0.152)\end{array}$ & $\begin{array}{l}-0.294^{* *} \\
(0.126)\end{array}$ & $\begin{array}{l}-0.032 \\
(0.164)\end{array}$ & $\begin{array}{l}-0.037 \\
(0.109)\end{array}$ & $\begin{array}{c}-0.240^{*} \\
(0.123)\end{array}$ & $\begin{array}{l}-0.267^{* *} \\
(0.123)\end{array}$ & $\begin{array}{l}-0.560 \\
(0.671)\end{array}$ & $\begin{array}{l}-0.146 \\
(0.568)\end{array}$ \\
\hline (Other) Firm controls & yes & yes & yes & yes & yes & yes & yes & yes \\
\hline Local trends & yes & yes & yes & yes & yes & yes & yes & yes \\
\hline Global trends & yes & yes & yes & yes & yes & yes & yes & yes \\
\hline$R^{2}$ & 0.030 & 0.031 & 0.041 & 0.081 & 0.089 & 0.122 & 0.008 & 0.015 \\
\hline $\mathrm{N}$ & 5,448 & 5,143 & 5,448 & 5,143 & 5,448 & 5,143 & 2,742 & 2,742 \\
\hline
\end{tabular}

Notes: *,***** significant at the 10,5 , and 1 percent level. Standard errors are clustered at four-digit NACE industries. All regressions include a constant term. Global industry controls include capital intensity and TFP growth rates of the four-digit NACE industries in the United States between 1998 and 2004. Local industry controls are capital intensity and RTFP average growth rates at the four-digit level in Hungary in the late 90s. Firm-level controls are subsidies and tax exceptions over sales, age, employment and RTFP in the initial year (1998). Source: APEH. 
Table A.8: Robustness Tests: All Firms

\begin{tabular}{|c|c|c|c|c|c|c|c|c|}
\hline & \multicolumn{2}{|c|}{$\Delta$ Capital Intensity } & \multicolumn{2}{|c|}{$\Delta$ Labor Productivity } & \multicolumn{2}{|c|}{$\Delta \mathrm{RTFP}$} & \multicolumn{2}{|c|}{$\Delta$ Leverage } \\
\hline & $(1)$ & $(2)$ & $(3)$ & $(4)$ & (5) & (6) & (7) & (8) \\
\hline Home & $\begin{array}{l}0.218^{* * * *} \\
(0.028)\end{array}$ & $\begin{array}{l}0.177^{* * * *} \\
(0.036)\end{array}$ & $\begin{array}{l}0.090^{* * *} \\
(0.021)\end{array}$ & $\begin{array}{l}-0.014 \\
(0.025)\end{array}$ & $\begin{array}{l}0.067^{* * * *} \\
(0.023)\end{array}$ & $\begin{array}{l}0.004 \\
(0.019)\end{array}$ & $\begin{array}{l}0.204^{* * *} \\
(0.079)\end{array}$ & $\begin{array}{l}0.082 \\
(0.104)\end{array}$ \\
\hline Home* Fin. dep. & & $\begin{array}{l}0.189^{*} \\
(0.092)\end{array}$ & & $\begin{array}{l}0.138^{* *} \\
(0.069)\end{array}$ & & $\begin{array}{l}0.115^{* *} \\
(0.055)\end{array}$ & & $\begin{array}{l}0.551^{* *} \\
(0.275)\end{array}$ \\
\hline Fin. dep. & & $\begin{array}{l}-0.153^{*} \\
(0.081)\end{array}$ & & $\begin{array}{l}0.427^{* * *} \\
(0.062)\end{array}$ & & $\begin{array}{l}0.269^{* *} \\
(0.116)\end{array}$ & & $\begin{array}{l}-0.355 \\
(0.237)\end{array}$ \\
\hline Firm-level controls & yes & yes & yes & yes & yes & yes & yes & yes \\
\hline Local trends & yes & yes & yes & yes & yes & yes & yes & yes \\
\hline Global trends & yes & yes & yes & yes & yes & yes & yes & yes \\
\hline$R^{2}$ & 0.019 & 0.023 & 0.021 & 0.103 & 0.065 & 0.082 & 0.007 & 0.008 \\
\hline $\mathrm{N}$ & 7,247 & 6,930 & 7,247 & 6,930 & 7,247 & 6,930 & 3,138 & 3,104 \\
\hline
\end{tabular}

Table A.9: Panel Regressions: Investment in Capital and Productivity

\begin{tabular}{|c|c|c|c|c|c|c|c|c|c|}
\hline & \multicolumn{3}{|c|}{ Log Capital Intensity } & \multicolumn{3}{|c|}{ Log Labor Productivity } & \multicolumn{3}{|c|}{ Log RTFP } \\
\hline & $(1)$ & $(2)$ & $(3)$ & (4) & $(5)$ & $(6)$ & $(7)$ & $(8)$ & $(9)$ \\
\hline Home*Reform & $\begin{array}{l}0.208^{* * *} \\
(0.015)\end{array}$ & $\begin{array}{l}0.251^{* * *} \\
(0.015)\end{array}$ & $\begin{array}{l}0.231^{* * *} \\
(0.016)\end{array}$ & $\begin{array}{l}0.062^{* * *} \\
(0.012)\end{array}$ & $\begin{array}{l}0.070^{* * *} \\
(0.016)\end{array}$ & $\begin{array}{l}0.043^{* * *} \\
(0.014)\end{array}$ & $\begin{array}{l}0.076^{* * *} \\
(0.012)\end{array}$ & $\begin{array}{l}0.056^{* * *} \\
(0.017)\end{array}$ & $\begin{array}{l}0.051^{* * *} \\
(0.014)\end{array}$ \\
\hline Reform & $\begin{array}{l}0.017 \\
(0.016)\end{array}$ & & & $\begin{array}{l}0.099^{* * *} \\
(0.017)\end{array}$ & & & $\begin{array}{l}0.020 \\
(0.015)\end{array}$ & & \\
\hline Firm FE & yes & yes & yes & yes & yes & yes & yes & yes & yes \\
\hline Sector*Year FE & & yes & yes & & yes & yes & & yes & yes \\
\hline Balanced panel & no & no & yes & no & no & yes & no & no & yes \\
\hline$R^{2}$ & 0.880 & 0.882 & 0.871 & 0.784 & 0.791 & 0.805 & 0.809 & 0.814 & 0.826 \\
\hline $\mathrm{N}$ & 59,976 & 59,976 & 38,136 & 60,864 & 60,864 & 38,136 & 59,771 & 59,771 & 38,136 \\
\hline
\end{tabular}

Notes: ${ }^{*}, * * * * *$ significant at the 10,5 , and 1 percent level. Standard errors are clustered at year and four-digit NACE industries. All regressions include firm-fixed effects. Regressions (2), (3), (5), (6), (8), (9) include four-digit NACE industries-year fixed effects. Regressions (1), (2), (4), (5), (7) and (8) include all firms with five or more employees. Regressions (3), (6) and (9) are estimated for the balance panel employed in Table 5. Source: APEH. 
Table A.10: Results By Industry

\begin{tabular}{|c|c|c|c|c|c|}
\hline & \multicolumn{4}{|c|}{$\begin{array}{l}\text { Differential Impact on } \\
\text { Home Firms }\end{array}$} & \multirow{2}{*}{$\begin{array}{l}\frac{\text { Foreign Firms }}{\Delta \text { Markups }} \\
(5)\end{array}$} \\
\hline & $\begin{array}{l}\Delta \text { Capital } \\
\text { Intensity } \\
(1)\end{array}$ & $\begin{array}{l}\Delta \text { Labor } \\
\text { Productivity } \\
(2)\end{array}$ & $\begin{array}{l}\Delta \mathrm{RTFP} \\
(3)\end{array}$ & $\begin{array}{l}\Delta \text { Leverage } \\
(4)\end{array}$ & \\
\hline $\begin{array}{l}\text { H}^{*} \text { Food \& Beverage } \\
(\text { Foreign in col }(5))\end{array}$ & $\begin{array}{l}0.266^{* * *} \\
(0.066)\end{array}$ & $\begin{array}{l}0.131^{* * *} \\
(0.009)\end{array}$ & $\begin{array}{l}0.106^{* * *} \\
(0.011)\end{array}$ & $\begin{array}{l}0.270^{* * *} \\
(0.025)\end{array}$ & $\begin{array}{l}-0.031^{* *} \\
(0.011)\end{array}$ \\
\hline $\begin{array}{l}\mathrm{H}^{*} \text { Textiles } \\
(\text { Foreign in col }(5))\end{array}$ & $\begin{array}{l}0.132^{*} \\
(0.068)\end{array}$ & $\begin{array}{l}0.021^{* * *} \\
(0.005)\end{array}$ & $\begin{array}{l}0.001 \\
(0.004)\end{array}$ & $\begin{array}{l}0.256^{* * *} \\
(0.020)\end{array}$ & $\begin{array}{l}0.049^{* * *} \\
(0.004)\end{array}$ \\
\hline $\begin{array}{l}\mathrm{H}^{*} \text { Wood and of Wood } \\
\text { (Foreign in col }(5))\end{array}$ & $\begin{array}{l}0.300^{* * *} \\
(0.109)\end{array}$ & $\begin{array}{l}0.158^{* * *} \\
(0.003)\end{array}$ & $\begin{array}{l}0.128^{* * *} \\
(0.002)\end{array}$ & $\begin{array}{l}0.185^{* * *} \\
(0.010)\end{array}$ & $\begin{array}{l}-0.076^{* * *} \\
(0.002)\end{array}$ \\
\hline $\begin{array}{l}\mathrm{H}^{*} \text { Pulp, Paper \& Printing } \\
\text { (Foreign in col }(5))\end{array}$ & $\begin{array}{l}0.285^{* * *} \\
(0.047)\end{array}$ & $\begin{array}{l}-0.007 \\
(0.007)\end{array}$ & $\begin{array}{l}-0.069^{* * *} \\
(0.005)\end{array}$ & $\begin{array}{l}0.406^{* * *} \\
(0.019)\end{array}$ & $\begin{array}{l}0.015^{* *} \\
(0.005)\end{array}$ \\
\hline $\begin{array}{l}\mathrm{H}^{*} \text { Chemical, Rubber \& Plastic } \\
\text { (Foreign in col }(5) \text { ) }\end{array}$ & $\begin{array}{l}0.191^{* * *} \\
(0.055)\end{array}$ & $\begin{array}{l}0.022^{* * *} \\
(0.006)\end{array}$ & $\begin{array}{l}-0.008 \\
(0.006)\end{array}$ & $\begin{array}{l}0.425^{* * *} \\
(0.023)\end{array}$ & $\begin{array}{l}-0.013^{*} \\
(0.006)\end{array}$ \\
\hline $\begin{array}{l}\mathrm{H}^{*} \text { Basic Metals } \\
(\text { Foreign in col }(5))\end{array}$ & $\begin{array}{l}0.322^{* * *} \\
(0.067)\end{array}$ & $\begin{array}{l}0.076^{* * *} \\
(0.006)\end{array}$ & $\begin{array}{l}0.048^{* * *} \\
(0.016)\end{array}$ & $\begin{array}{l}0.300^{* * *} \\
(0.016)\end{array}$ & $\begin{array}{l}-0.032^{* * *} \\
(0.005)\end{array}$ \\
\hline $\begin{array}{l}\mathrm{H}^{*} \text { Machinery } \\
(\text { Foreign in col }(5))\end{array}$ & $\begin{array}{l}0.245^{* * *} \\
(0.039)\end{array}$ & $\begin{array}{l}0.047^{* * * *} \\
(0.006)\end{array}$ & $\begin{array}{l}-0.016^{* * *} \\
(0.017)\end{array}$ & $\begin{array}{l}-0.472^{* * *} \\
(0.017)\end{array}$ & $\begin{array}{l}-0.057^{* * *} \\
(0.005)\end{array}$ \\
\hline $\begin{array}{l}\mathrm{H}^{*} \text { Electrical Equipment } \\
(\text { Foreign in col }(5))\end{array}$ & $\begin{array}{l}0.292^{* * *} \\
(0.058)\end{array}$ & $\begin{array}{l}0.008 \\
(0.020)\end{array}$ & $\begin{array}{l}0.033^{*} \\
(0.048)\end{array}$ & $\begin{array}{l}0.440^{* * *} \\
(0.047)\end{array}$ & $\begin{array}{l}-0.028^{* * *} \\
(0.007)\end{array}$ \\
\hline $\begin{array}{l}\mathrm{H}^{*} \text { Transport } \\
(\text { Foreign in col }(5))\end{array}$ & $\begin{array}{l}0.334^{* * *} \\
(0.127)\end{array}$ & $\begin{array}{l}0.138^{* * *} \\
(0.012)\end{array}$ & $\begin{array}{l}0.166^{* * *} \\
(0.027)\end{array}$ & $\begin{array}{l}0.192^{* * *} \\
(0.029)\end{array}$ & $\begin{array}{l}-0.054^{* * *} \\
(0.010)\end{array}$ \\
\hline $\begin{array}{l}\mathrm{H}^{*} \text { Manufacturing NEC } \\
(\text { Foreign in col }(5))\end{array}$ & $\begin{array}{l}0.174^{* *} \\
(0.079)\end{array}$ & $\begin{array}{l}0.105^{* * *} \\
(0.006)\end{array}$ & $\begin{array}{l}0.080^{* * *} \\
(0.004)\end{array}$ & $\begin{array}{l}0.169^{* * *} \\
(0.021)\end{array}$ & $\begin{array}{l}-0.052^{* * *} \\
(0.004)\end{array}$ \\
\hline Firm-level controls & Yes & Yes & Yes & Yes & Yes \\
\hline Global trends & Yes & Yes & Yes & Yes & Yes \\
\hline Local trends & Yes & Yes & Yes & Yes & Yes \\
\hline Sector FE & Yes & Yes & Yes & Yes & Yes \\
\hline$R^{2}$ & 0.037 & 0.144 & 0.199 & 0.017 & 0.059 \\
\hline $\mathrm{N}$ & 5,448 & 5,448 & 5,448 & 2,742 & 5,376 \\
\hline
\end{tabular}

Notes: *,**, *** significant at the 10, 5, and 1 percent level. Standard errors are clustered at industry level. Columns (1)-(4) report the differential impact of the reform on home firms' capital intensity, labor productivity, RTFP and leverage. Column (5) presents the differential impact of the reform on foreign firms' markups. All regressions include sector fixed-effects at two-digit NACE industries. Global industry controls include capital intensity and TFP growth rates of the four-digit NACE industries in the United States between 1998 and 2004 . Local industry controls are capital intensity and RTFP average growth rates at the four-digit level in Hungary in the late 90s. Firm-level controls are age, employment and RTFP in the initial year (1998). Source: APEH. 
Table A.11: Falsification Test: Effect By Year

\begin{tabular}{|c|c|c|c|}
\hline & $\begin{array}{l}\text { Log Capital Intensity } \\
\text { (1) }\end{array}$ & $\begin{array}{l}\text { Log Labor Productivity } \\
\text { (2) }\end{array}$ & $\begin{array}{l}\text { Log RTFP } \\
(3)\end{array}$ \\
\hline 1998*Home & $\begin{array}{l}-0.636^{* * *} \\
(0.041)\end{array}$ & $\begin{array}{l}-0.428^{* * *} \\
(0.027)\end{array}$ & $\begin{array}{l}-0.094^{* * *} \\
(0.013)\end{array}$ \\
\hline 1999*Home & $\begin{array}{l}-0.623^{* * *} \\
(0.038)\end{array}$ & $\begin{array}{l}-0.461^{* * *} \\
(0.030)\end{array}$ & $\begin{array}{l}-0.116^{* * *} \\
(0.019)\end{array}$ \\
\hline $2000 *$ Home & $\begin{array}{l}-0.602^{* * *} \\
(0.034)\end{array}$ & $\begin{array}{l}-0.447^{* * *} \\
(0.029)\end{array}$ & $\begin{array}{l}-0.107^{* * *} \\
(0.018)\end{array}$ \\
\hline 2001*Home & $\begin{array}{l}-0.504^{* * *} \\
(0.035)\end{array}$ & $\begin{array}{l}-0.389^{* * *} \\
(0.028)\end{array}$ & $\begin{array}{l}-0.059^{* * *} \\
(0.019)\end{array}$ \\
\hline $2002 *$ Home & $\begin{array}{l}-0.462^{* * *} \\
(0.035)\end{array}$ & $\begin{array}{l}-0.357^{* * *} \\
(0.031)\end{array}$ & $\begin{array}{l}-0.009 \\
(0.019)\end{array}$ \\
\hline $2003 *$ Home & $\begin{array}{l}-0.411^{* * *} \\
(0.034)\end{array}$ & $\begin{array}{l}-0.376^{* * *} \\
(0.025)\end{array}$ & $\begin{array}{l}-0.038^{* *} \\
(0.019)\end{array}$ \\
\hline $2004 *$ Home & $\begin{array}{l}-0.370^{* * *} \\
(0.036)\end{array}$ & $\begin{array}{l}-0.337^{* * *} \\
(0.025)\end{array}$ & $\begin{array}{l}0.029 \\
(0.020)\end{array}$ \\
\hline Year FE & Yes & Yes & Yes \\
\hline Sector FE & Yes & Yes & Yes \\
\hline Firm-level controls & Yes & Yes & Yes \\
\hline Global trends & Yes & Yes & Yes \\
\hline $\begin{array}{l}R^{2} \\
\mathrm{~N}\end{array}$ & $\begin{array}{l}0.971 \\
38,136\end{array}$ & $\begin{array}{l}0.989 \\
38,136\end{array}$ & $\begin{array}{l}0.894 \\
38,136\end{array}$ \\
\hline \multicolumn{4}{|c|}{ F Tests on Equality of Coefficients } \\
\hline $\begin{array}{l}\text { F-stat: } 1998 * \text { Home }=2000 * \text { Home } \\
\text { pvalue }\end{array}$ & $\begin{array}{l}0.41 \\
0.5216\end{array}$ & $\begin{array}{l}0.24 \\
0.6257\end{array}$ & $\begin{array}{l}0.37 \\
0.5413\end{array}$ \\
\hline $\begin{array}{l}\text { F-stat: } 2000 * \text { Home }=2002 * \text { Home } \\
\text { pvalue }\end{array}$ & $\begin{array}{l}8.83 \\
0.0030\end{array}$ & $\begin{array}{l}4.76 \\
0.0293\end{array}$ & $\begin{array}{l}14.45 \\
0.0002\end{array}$ \\
\hline $\begin{array}{l}\text { F-stat: } 2000 * \text { Home }=2003 * \text { Home } \\
\text { pvalue }\end{array}$ & $\begin{array}{l}16.58 \\
0.0000\end{array}$ & $\begin{array}{l}3.66 \\
0.0558\end{array}$ & $\begin{array}{l}7.20 \\
0.0074\end{array}$ \\
\hline $\begin{array}{l}\text { F-stat: } 2000 * \text { Home }=2004 * \text { Home } \\
\text { pvalue }\end{array}$ & $\begin{array}{l}23.67 \\
0.0000\end{array}$ & $\begin{array}{l}8.57 \\
0.0035\end{array}$ & $\begin{array}{l}25.47 \\
0.0000\end{array}$ \\
\hline
\end{tabular}

Notes: ${ }^{*}, * *, * * *$ significant at the 10,5 , and 1 percent level. Standard errors are clustered at year and four-digit NACE industries. Global industry controls include capital intensity and TFP of the four-digit NACE industries in the United States between 1998 and 2004. Firm-level controls are employment, labor productivity and age in the initial year (1998). All regressions include four-digit industries fixed-effects. Source: APEH. 
Table A.12: Falsification Test-Year 1998: Investment in Capital and Productivity

\begin{tabular}{|c|c|c|c|c|c|c|c|c|c|}
\hline & \multicolumn{3}{|c|}{$\Delta$ Capital Intensity } & \multicolumn{3}{|c|}{$\Delta$ Labor Productivity } & \multicolumn{3}{|c|}{$\Delta$ RTFP } \\
\hline & (1) & $(2)$ & (3) & (4) & (5) & (6) & (7) & $(8)$ & (9) \\
\hline Home & $\begin{array}{l}0.012 \\
(0.022)\end{array}$ & $\begin{array}{l}0.027 \\
(0.021)\end{array}$ & $\begin{array}{l}0.023 \\
(0.020)\end{array}$ & $\begin{array}{l}-0.018 \\
(0.020)\end{array}$ & $\begin{array}{l}-0.025 \\
(0.021)\end{array}$ & $\begin{array}{l}-0.022 \\
(0.021)\end{array}$ & $\begin{array}{l}0.020 \\
(0.017)\end{array}$ & $\begin{array}{l}-0.017 \\
(0.018)\end{array}$ & $\begin{array}{l}-0.016 \\
(0.018)\end{array}$ \\
\hline Firm controls & & yes & yes & & yes & yes & & yes & yes \\
\hline Local trends & & & yes & & & yes & & & yes \\
\hline Global trends & & & yes & & & yes & & & yes \\
\hline$R^{2}$ & 0.000 & 0.011 & 0.018 & 0.000 & 0.048 & 0.062 & 0.000 & 0.118 & 0.121 \\
\hline $\mathrm{N}$ & 4,366 & 4,366 & 4,366 & 4,366 & 4,366 & 4,366 & 4,366 & 4,366 & 4,366 \\
\hline
\end{tabular}

Notes: $*, * *, * * *$ significant at the 10,5, and 1 percent level. Period 1996-2000. Standard errors are clustered at four-digit NACE industries. All regressions include a constant term. Global industry controls include capital intensity and TFP growth rates of the four-digit NACE industries in the Unites States between 1996-2000. Local industry controls are capital intensity and RTFP average growth rates at the four-digit level in Hungary in the early 90s. Firm-level controls are age, employment and RTFP in the initial year (1996). Source: APEH.

\section{Table A.13: Quartiles of Financial Dependence: Investment in Capital and PRODUCTIVITY}

\begin{tabular}{|c|c|c|c|c|c|c|c|c|c|}
\hline & \multicolumn{3}{|c|}{$\Delta$ Capital Intensity } & \multicolumn{3}{|c|}{$\Delta$ Labor Productivity } & \multicolumn{3}{|c|}{$\Delta \mathrm{RTFP}$} \\
\hline & $(1)$ & $(2)$ & (3) & (4) & $(5)$ & (6) & (7) & $(8)$ & (9) \\
\hline Home ${ }^{*} 1($ Fin.Dep. $=1)$ & $\begin{array}{l}0.225^{* * *} \\
(0.033)\end{array}$ & $\begin{array}{l}0.234^{* * *} \\
(0.035)\end{array}$ & $\begin{array}{l}0.234^{* * * *} \\
(0.035)\end{array}$ & $\begin{array}{l}0.058^{* * *} \\
(0.013)\end{array}$ & $\begin{array}{l}0.017 \\
(0.034)\end{array}$ & $\begin{array}{l}0.034 \\
(0.031)\end{array}$ & $\begin{array}{l}0.087^{* * *} \\
(0.015)\end{array}$ & $\begin{array}{l}-0.009 \\
(0.027)\end{array}$ & $\begin{array}{l}-0.014 \\
(0.028)\end{array}$ \\
\hline Home*1(Fin.Dep.=2) & $\begin{array}{l}0.226^{* * *} \\
(0.050)\end{array}$ & $\begin{array}{l}0.226 * * * \\
(0.047)\end{array}$ & $\begin{array}{l}0.228^{* * *} \\
(0.046)\end{array}$ & $\begin{array}{l}0.089^{*} \\
(0.043)\end{array}$ & $\begin{array}{l}0.057^{* *} \\
(0.028)\end{array}$ & $\begin{array}{l}0.052^{*} \\
(0.029)\end{array}$ & $\begin{array}{l}0.089^{*} \\
(0.044)\end{array}$ & $\begin{array}{l}0.024 \\
(0.042)\end{array}$ & $\begin{array}{l}0.022 \\
(0.042)\end{array}$ \\
\hline Home*1(Fin.Dep.=3) & $\begin{array}{l}0.271^{* * *} \\
(0.056)\end{array}$ & $\begin{array}{l}0.285^{* * *} \\
(0.055)\end{array}$ & $\begin{array}{l}0.279^{* * *} \\
(0.054)\end{array}$ & $\begin{array}{l}0.067^{* * *} \\
(0.020)\end{array}$ & $\begin{array}{l}0.051^{*} \\
(0.026)\end{array}$ & $\begin{array}{l}0.051^{*} \\
(0.026)\end{array}$ & $\begin{array}{l}0.083^{* * *} \\
(0.021)\end{array}$ & $\begin{array}{l}0.042^{*} \\
(0.022)\end{array}$ & $\begin{array}{l}0.036^{*} \\
(0.022)\end{array}$ \\
\hline Home ${ }^{*} 1($ Fin.Dep. $=4)$ & $\begin{array}{l}0.253^{* * *} \\
(0.041)\end{array}$ & $\begin{array}{l}0.292^{* * *} \\
(0.040)\end{array}$ & $\begin{array}{l}0.298^{* * *} \\
(0.042)\end{array}$ & $\begin{array}{l}0.077^{* *} \\
(0.030)\end{array}$ & $\begin{array}{l}0.080^{* *} \\
(0.031)\end{array}$ & $\begin{array}{l}0.091 * * \\
(0.035)\end{array}$ & $\begin{array}{l}0.156^{* * *} \\
(0.047)\end{array}$ & $\begin{array}{l}0.083^{* *} \\
(0.038)\end{array}$ & $\begin{array}{l}0.075^{* *} \\
(0.036)\end{array}$ \\
\hline 1(Fin.Dep.=2) & $\begin{array}{l}0.014 \\
(0.057)\end{array}$ & $\begin{array}{l}0.033 \\
(0.054)\end{array}$ & $\begin{array}{l}0.028 \\
(0.054)\end{array}$ & $\begin{array}{l}0.132 \\
(0.086)\end{array}$ & $\begin{array}{l}0.160^{* * *} \\
(0.051)\end{array}$ & $\begin{array}{l}0.172^{* * *} \\
(0.051)\end{array}$ & $\begin{array}{l}0.118 \\
(0.071)\end{array}$ & $\begin{array}{l}0.138^{* *} \\
(0.064)\end{array}$ & $\begin{array}{l}0.134^{* *} \\
(0.061)\end{array}$ \\
\hline 1(Fin.Dep.=3) & $\begin{array}{l}-0.007 \\
(0.043)\end{array}$ & $\begin{array}{l}0.004 \\
(0.044)\end{array}$ & $\begin{array}{l}-0.010 \\
(0.046)\end{array}$ & $\begin{array}{l}0.139 * \\
(0.078)\end{array}$ & $\begin{array}{l}0.160^{* * *} \\
(0.054)\end{array}$ & $\begin{array}{l}0.180^{* * *} \\
(0.052)\end{array}$ & $\begin{array}{l}0.106 \\
(0.068)\end{array}$ & $\begin{array}{l}0.125^{* *} \\
(0.051)\end{array}$ & $\begin{array}{l}0.119 * * \\
(0.051)\end{array}$ \\
\hline 1(Fin.Dep.=4) & $\begin{array}{l}-0.018 \\
(0.056)\end{array}$ & $\begin{array}{l}-0.015 \\
(0.059)\end{array}$ & $\begin{array}{l}-0.034 \\
(0.072)\end{array}$ & $\begin{array}{l}0.163^{*} \\
(0.088)\end{array}$ & $\begin{array}{l}0.190^{* * *} \\
(0.057)\end{array}$ & $\begin{array}{l}0.187 * * * \\
(0.061)\end{array}$ & $\begin{array}{l}0.055 \\
(0.080)\end{array}$ & $\begin{array}{l}0.124^{* *} \\
(0.058)\end{array}$ & $\begin{array}{l}0.143^{* *} \\
(0.057)\end{array}$ \\
\hline Firm-level controls & & yes & yes & & yes & yes & & yes & yes \\
\hline Local trends & & & yes & & & yes & & & yes \\
\hline Global trends & & & yes & & & yes & & & yes \\
\hline$R^{2}$ & 0.020 & 0.031 & 0.032 & 0.030 & 0.069 & 0.082 & 0.022 & 0.109 & 0.114 \\
\hline $\mathrm{N}$ & 5,143 & 5,143 & 5,143 & 5,143 & 5,143 & 5,143 & 5,143 & 5,143 & 5,143 \\
\hline
\end{tabular}




\section{Table A.14: Financial Dependence: Investment in Capital and Productivity- Robustness Test}

\begin{tabular}{|c|c|c|c|c|c|c|c|c|c|}
\hline & \multicolumn{3}{|c|}{$\Delta$ Capital Intensity } & \multicolumn{3}{|c|}{$\Delta$ Labor Productivity } & \multicolumn{3}{|c|}{$\Delta \mathrm{RTFP}$} \\
\hline & (1) & (2) & (3) & (4) & (5) & (6) & $(7)$ & (8) & (9) \\
\hline Home & $\begin{array}{l}0.246^{* * *} \\
(0.028)\end{array}$ & $\begin{array}{l}0.253^{* * *} \\
(0.031)\end{array}$ & $\begin{array}{l}0.252^{* * * *} \\
(0.031)\end{array}$ & $\begin{array}{l}0.061^{* * * *} \\
(0.021)\end{array}$ & $\begin{array}{l}0.019 \\
(0.016)\end{array}$ & $\begin{array}{l}0.016 \\
(0.015)\end{array}$ & $\begin{array}{l}0.080^{* * *} \\
(0.018)\end{array}$ & $\begin{array}{l}-0.015 \\
(0.025)\end{array}$ & $\begin{array}{l}-0.023 \\
(0.025)\end{array}$ \\
\hline Home* Fin. dep. & $\begin{array}{l}0.117 \\
(0.093)\end{array}$ & $\begin{array}{l}0.163^{*} \\
(0.083)\end{array}$ & $\begin{array}{l}0.162^{*} \\
(0.084)\end{array}$ & $\begin{array}{l}0.080 \\
(0.069)\end{array}$ & $\begin{array}{l}0.158^{* * *} \\
(0.054)\end{array}$ & $\begin{array}{l}0.154^{* * *} \\
(0.049)\end{array}$ & $\begin{array}{l}0.120 \\
(0.086)\end{array}$ & $\begin{array}{l}0.218^{* * *} \\
(0.084)\end{array}$ & $\begin{array}{l}0.208^{* * * *} \\
(0.072)\end{array}$ \\
\hline Fin. dep. & $\begin{array}{l}-0.066 \\
(0.059)\end{array}$ & $\begin{array}{l}-0.071 \\
(0.067)\end{array}$ & $\begin{array}{l}-0.059 \\
(0.073)\end{array}$ & $\begin{array}{l}0.285^{* * * *} \\
(0.083)\end{array}$ & $\begin{array}{l}0.322^{* * *} \\
(0.108)\end{array}$ & $\begin{array}{l}0.329^{* *} \\
(0.122)\end{array}$ & $\begin{array}{l}0.129 \\
(0.098)\end{array}$ & $\begin{array}{l}0.193^{*} \\
(0.098)\end{array}$ & $\begin{array}{l}0.245^{* * *} \\
(0.089)\end{array}$ \\
\hline Firm-level controls & & yes & yes & & yes & yes & & yes & yes \\
\hline Local trends & & & yes & & & yes & & & yes \\
\hline Global trends & & & yes & & & yes & & & yes \\
\hline$R^{2}$ & 0.022 & 0.034 & 0.034 & 0.035 & 0.075 & 0.082 & 0.022 & 0.115 & 0.124 \\
\hline $\mathrm{N}$ & 4,915 & 4,915 & 4,915 & 4,915 & 4,915 & 4,915 & 4,915 & 4,915 & 4,915 \\
\hline
\end{tabular}

Table A.15: Export Platforms

\begin{tabular}{|c|c|c|c|c|c|c|c|c|}
\hline & \multicolumn{2}{|c|}{$\Delta$ Capital Intensity } & \multicolumn{2}{|c|}{$\Delta$ Labor Productivity } & \multicolumn{2}{|c|}{$\Delta$ RTFP } & \multicolumn{2}{|c|}{$\Delta$ Leverage } \\
\hline & $90 \%$ & $75 \%$ & $90 \%$ & $75 \%$ & $90 \%$ & $75 \%$ & $90 \%$ & $75 \%$ \\
\hline & (1) & (2) & (3) & $(4)$ & (5) & $(6)$ & $(7)$ & (8) \\
\hline Home & $\begin{array}{l}0.214^{* * *} \\
(0.027)\end{array}$ & $\begin{array}{l}0.212^{* * *} \\
(0.029)\end{array}$ & $\begin{array}{l}0.036^{*} \\
(0.020)\end{array}$ & $\begin{array}{l}0.022 \\
(0.021)\end{array}$ & $\begin{array}{l}0.024^{*} \\
(0.006)\end{array}$ & $\begin{array}{l}0.018 \\
(0.011)\end{array}$ & $\begin{array}{l}0.140 \\
(0.108)\end{array}$ & $\begin{array}{l}0.102 \\
(0.113)\end{array}$ \\
\hline Home* Fin. dep. & $\begin{array}{l}0.174^{*} \\
(0.089)\end{array}$ & $\begin{array}{l}0.212^{* *} \\
(0.101)\end{array}$ & $\begin{array}{l}0.081^{* *} \\
(0.038)\end{array}$ & $\begin{array}{l}0.076^{*} \\
(0.044)\end{array}$ & $\begin{array}{l}0.025^{*} \\
(0.007)\end{array}$ & $\begin{array}{l}0.031^{*} \\
(0.009)\end{array}$ & $\begin{array}{l}0.481^{*} \\
(0.288)\end{array}$ & $\begin{array}{l}0.643^{* *} \\
(0.300)\end{array}$ \\
\hline Fin. dep. & $\begin{array}{l}-0.055 \\
(0.093)\end{array}$ & $\begin{array}{l}-0.090 \\
(0.105)\end{array}$ & $\begin{array}{l}0.380^{* * *} \\
(0.101)\end{array}$ & $\begin{array}{l}0.380^{* * *} \\
(0.095)\end{array}$ & $\begin{array}{l}0.266^{* *} \\
(0.030)\end{array}$ & $\begin{array}{l}0.385^{*} \\
(0.107)\end{array}$ & $\begin{array}{l}-0.583^{* *} \\
(0.261)\end{array}$ & $\begin{array}{l}-0.748^{* * *} \\
(0.274)\end{array}$ \\
\hline Firm-level controls & yes & yes & yes & yes & yes & yes & yes & yes \\
\hline Local trends & yes & yes & yes & yes & yes & yes & yes & yes \\
\hline Global trends & yes & yes & yes & yes & yes & yes & yes & yes \\
\hline$R^{2}$ & 0.030 & 0.030 & 0.085 & 0.083 & 0.105 & 0.134 & 0.008 & 0.008 \\
\hline $\mathrm{N}$ & 4,789 & 4,667 & 4,789 & 4,667 & 4,789 & 4,667 & 2,311 & 2,249 \\
\hline
\end{tabular}

Notes: $*, * *, * * *$ significant at the 10,5 , and 1 percent level. Standard errors are clustered at four-digit NACE industries. All regressions include a constant term. Columns 1, 3, 5 and 7 restrict the analysis to foreign firms that export shares lower than $90 \%$ of their total sales. Columns $2,4,6$ and 8 restrict the analysis to foreign firms that export shares lower than $75 \%$. Global industry controls include capital intensity and TFP growth rates of the four-digit NACE industries in the United States between 1998 and 2004. Local industry controls are capital intensity and RTFP average growth rates at the four-digit level in Hungary in the late 90s. Firm-level controls are age, employment and RTFP in the initial year (1998). Source: APEH. 
Table A.16: SkILl-Intensity

\begin{tabular}{|c|c|c|c|c|}
\hline & \multicolumn{4}{|c|}{$\Delta$ Skill Intensity } \\
\hline & (1) & (2) & (3) & (4) \\
\hline Home & $\begin{array}{l}0.003^{*} \\
(0.002)\end{array}$ & $\begin{array}{l}0.014^{* *} \\
(0.006)\end{array}$ & $\begin{array}{l}0.013^{* *} \\
(0.006)\end{array}$ & $\begin{array}{l}-0.014^{* *} \\
(0.006)\end{array}$ \\
\hline Home.* Fin. dep. & & & & $\begin{array}{l}0.041^{* *} \\
(0.016)\end{array}$ \\
\hline Financial dependence & & & & $\begin{array}{l}0.021^{* *} \\
(0.009)\end{array}$ \\
\hline Firm-level control & & yes & yes & yes \\
\hline Local trend & & & yes & yes \\
\hline Global trends & & & yes & yes \\
\hline $\begin{array}{l}R^{2} \\
\mathrm{~N}\end{array}$ & $\begin{array}{l}0.004 \\
1,221\end{array}$ & $\begin{array}{l}0.028 \\
1,221\end{array}$ & $\begin{array}{l}0.038 \\
1,221\end{array}$ & $\begin{array}{l}0.053 \\
1,179\end{array}$ \\
\hline \multicolumn{5}{|c|}{$\begin{array}{l}\text { Notes: }{ }^{*},{ }^{*},{ }^{* *} \text { significant at the } 10,5, \text { and } 1 \text { percent level. Standard errors are } \\
\text { clustered at four-digit NACE industries. All regressions include a constant term. Fi- } \\
\text { nancial dependence is the Rajan and Zingales (1998) index. Global industry controls } \\
\text { include capital intensity and TFP growth rates of the four-digit NACE industries in } \\
\text { the United States between } 1998 \text { and } 2004 \text {. Local industry controls are capital inten- } \\
\text { sity and RTFP average growth rates at the four-digit level in Hungary in the late } \\
\text { 90s. Firm-level controls are age, employment and RTFP in the initial year (1998). } \\
\text { Source: APEH. }\end{array}$} \\
\hline
\end{tabular}


Table A.17: Falsification Test: Effect By Year

\begin{tabular}{ll}
\hline \hline & $\begin{array}{l}\text { Log Leverage } \\
(1)\end{array}$ \\
\hline $1999^{*}$ Home & $-0.137^{* *}$ \\
& $(0.055)$ \\
$2000 *$ Home & $-0.149^{* *}$ \\
& $(0.056)$ \\
$2001 *$ Home & -0.121 \\
& $(0.072)$ \\
$2002 *$ Home & 0.012 \\
& $(0.071)$ \\
$2003 *$ Home & 0.039 \\
& $(0.073)$ \\
$2004 *$ Home & $0.143^{* *}$ \\
& $(0.059)$ \\
Year FE & Yes \\
Sector FE & Yes \\
Firm-level controls & Yes \\
Global trends & Yes \\
$R^{2}$ & 0.830 \\
$\mathrm{~N}$ & 16,452 \\
\hline
\end{tabular}

F Tests on Equality of Coefficients

\begin{tabular}{ll}
\hline F-stat 1999-00 & 0.05 \\
pvalue & 0.8220 \\
F-stat 2000-02 & 6.05 \\
pvalue & 0.0231 \\
F-stat 2000-03 & 5.60 \\
pvalue & 0.0281 \\
F-stat 2000-04 & 12.71 \\
pvalue & 0.0019 \\
\hline \hline
\end{tabular}

Notes: $*, * *, * * *$ significant at the 10,5 , and 1 percent level. Standard errors are clustered at year and four-digit NACE industries. Global industry controls include capital intensity and TFP of the four-digit NACE industries in the United States between 1998 and 2004. Firm-level controls are employment, labor productivity and age in the initial year (1998). All regressions include four-digit industries fixed-effects. Source: APEH. 
Table A.18: Falsification Test: Effect By Year

\begin{tabular}{ll}
\hline \hline & Log Markup \\
& $(1)$ \\
\hline $1998^{*}$ Foreign & $0.096^{* * *}$ \\
& $(0.023)$ \\
$1999^{*}$ Foreign & $0.112^{* * *}$ \\
& $(0.021)$ \\
$2000^{*}$ Foreign & $0.099^{* * *}$ \\
& $(0.021)$ \\
$2001^{*}$ Foreign & $0.078^{* * *}$ \\
& $(0.022)$ \\
$2002^{*}$ Foreign & $0.078^{* * *}$ \\
$2003^{*}$ Foreign & $(0.021)$ \\
$2004^{*}$ Foreign & $0.062^{* * *}$ \\
& $(0.020)$ \\
Year FE & $0.051^{* *}$ \\
Sector FE & $(0.024)$ \\
Firm-level controls & Yes \\
Global trends & Yes \\
$R^{2}$ & Yes \\
\hline & Yes \\
& 0.190 \\
& 37,632 \\
\hline
\end{tabular}

F Tests on Equality of Coefficients

\begin{tabular}{ll}
\hline F-stat 1998-00 & 0.08 \\
pvalue & 0.7870 \\
F-stat 2000-02 & 3.49 \\
pvalue & 0.0766 \\
F-stat 2000-03 & 12.62 \\
pvalue & 0.0020 \\
F-stat 2000-04 & 9.10 \\
pvalue & 0.0068 \\
\hline
\end{tabular}

Notes: ${ }^{*},{ }^{* *}, * * *$ significant at the 10,5 , and 1 percent level. Standard errors are clustered at year and four-digit NACE industries. Global industry controls include capital intensity and TFP of the four-digit NACE industries in the United States between 1998 and 2004. Firm-level controls are employment, labor productivity and age in the initial year (1998). All regressions include four-digit industries fixed-effects.

Source: APEH. 
Table A.19: Markups: Falsification Test, Year 1998

\begin{tabular}{llll}
\hline \hline & \multicolumn{3}{c}{$\Delta$ Markups } \\
\cline { 2 - 4 } & $(1)$ & $(2)$ & $(3)$ \\
\hline Foreign & -0.003 & -0.007 & -0.006 \\
& $(0.012)$ & $(0.014)$ & $(0.014)$ \\
Firm controls & & yes & yes \\
Local trends & & & yes \\
Global trends & & & yes \\
$R^{2}$ & 0.000 & 0.024 & 0.028 \\
$\mathrm{~N}$ & 3,953 & 3,953 & 3,953 \\
\hline \hline
\end{tabular}

Notes: $*, * *, * * *$ significant at the 10,5 , and 1 percent level. Standard errors are clustered at four-digit NACE industries. All regressions include a constant term. Global industry controls include capital intensity and TFP growth rates of the four-digit NACE industries in the United States between 1996 and 2000. Local industry controls are capital intensity and RTFP average growth rates at the four-digit level in Hungary in the early 90s. Firm-level controls are age, employment and RTFP in the initial year (1996). Source: APEH.

Table A.20: Markups: Controlling For Subsidies And Exceptions

\begin{tabular}{|c|c|c|}
\hline & \multicolumn{2}{|c|}{$\Delta$ Markups } \\
\hline & (1) & (2) \\
\hline Foreign & $\begin{array}{l}-0.027^{* *} \\
(0.011)\end{array}$ & $\begin{array}{l}0.028^{*} \\
(0.015)\end{array}$ \\
\hline Foreign * Fin. dep. & & $\begin{array}{l}-0.202^{* * *} \\
(0.044)\end{array}$ \\
\hline Fin. dep. & & $\begin{array}{l}0.212^{* * *} \\
(0.070)\end{array}$ \\
\hline Subsidy and tax ex. & $\begin{array}{c}-0.202 \\
(0.150)\end{array}$ & $\begin{array}{l}-0.246 \\
(0.154)\end{array}$ \\
\hline (Previous) Firm controls & yes & yes \\
\hline Local trends & yes & yes \\
\hline Global trends & yes & yes \\
\hline$R^{2}$ & 0.024 & 0.058 \\
\hline $\mathrm{N}$ & 5,376 & 5,086 \\
\hline $\begin{array}{l}\text { Notes: } *, * *, * * * \text { significant at } \\
\text { industries. All regressions incl } \\
\text { growth rates of the four-digit } \\
\text { controls are capital intensity a } \\
\text { Firm-level controls are subsidie } \\
\text { APEH. }\end{array}$ & $\begin{array}{l}\text { andard errol } \\
\text { try controls } \\
\text { thates betwe } \\
\text { the four-dig } \\
\text { ent and RTH }\end{array}$ & $\begin{array}{l}\text { red at four-d } \\
\text { ital intensity } \\
2004 \text {. Loc: } \\
\text { ungary in th } \\
\text { ial year (199 }\end{array}$ \\
\hline
\end{tabular}


Table A.21: MARKups: InCluding ALl Firms

\begin{tabular}{lll}
\hline \hline & \multicolumn{2}{c}{$\Delta$ Markups } \\
\cline { 2 - 3 } & $(1)$ & $(2)$ \\
\hline Foreign & $-0.026^{*}$ & -0.001 \\
& $(0.012)$ & $(0.016)$ \\
Foreign*Fin. dep. & & $-0.106^{* *}$ \\
& & $(0.047)$ \\
Fin. dep. & & $0.165^{* *}$ \\
& & $(0.062)$ \\
Firm-level controls & yes & yes \\
Local trends & yes & yes \\
Global trends & yes & yes \\
$R^{2}$ & 0.028 & 0.034 \\
$\mathrm{~N}$ & 7,039 & 6,921 \\
\hline \hline
\end{tabular}

Notes: $*, * *, * * *$ significant at the 10,5 , and 1 percent level. Standard errors are clustered at four-digit NACE industries. All regressions include a constant term. Global industry controls include capital intensity and TFP growth rates of the four-digit NACE industries in the United States between 1998 and 2004. Local industry controls are capital intensity and RTFP average growth rates at the four-digit level in Hungary in the late 90s. Firm-level controls are age, employment and RTFP in the initial year (1998). Source: APEH.

Table A.22: Markups: PCM, WLP And DLTL Methodologies

\begin{tabular}{|c|c|c|c|}
\hline & \multicolumn{3}{|c|}{$\Delta$ Markups } \\
\hline & $\begin{array}{l}\text { PCM } \\
\text { (1) }\end{array}$ & $\begin{array}{l}\text { WLP } \\
(2)\end{array}$ & $\begin{array}{l}\text { DLTL } \\
(3)\end{array}$ \\
\hline Foreign & $\begin{array}{l}-0.044 \\
(0.041)\end{array}$ & $\begin{array}{l}-0.032^{* *} \\
(0.013)\end{array}$ & $\begin{array}{l}-0.013 \\
(0.028)\end{array}$ \\
\hline Foreign*Fin. dep. & $\begin{array}{l}-0.333^{* * *} \\
(0.112)\end{array}$ & $\begin{array}{l}-0.086^{* *} \\
(0.036)\end{array}$ & $\begin{array}{l}-0.186^{* *} \\
(0.073)\end{array}$ \\
\hline Financial dependence & $\begin{array}{l}0.236^{* *} \\
(0.100)\end{array}$ & $\begin{array}{l}0.087^{*} \\
(0.043)\end{array}$ & $\begin{array}{l}0.003 \\
(0.073)\end{array}$ \\
\hline Firm-level controls & yes & yes & yes \\
\hline Local trends & yes & yes & yes \\
\hline Global trends & yes & yes & yes \\
\hline$R^{2}$ & 0.008 & 0.036 & 0.023 \\
\hline $\mathrm{N}$ & 4,811 & 4,646 & 4,621 \\
\hline
\end{tabular}


Table A.23: Markups: Controlling for Export Platforms

\begin{tabular}{|c|c|c|c|c|}
\hline & \multicolumn{4}{|c|}{$\Delta$ Markups } \\
\hline & $90 \%$ & $75 \%$ & $90 \%$ & $75 \%$ \\
\hline & (1) & $(2)$ & (3) & (4) \\
\hline Foreign & $\begin{array}{l}-0.026^{* *} \\
(0.010)\end{array}$ & $\begin{array}{l}0.015 \\
(0.014)\end{array}$ & $\begin{array}{l}-0.022^{*} \\
(0.011)\end{array}$ & $\begin{array}{l}0.017 \\
(0.011)\end{array}$ \\
\hline Foreign * Fin. dep. & & $\begin{array}{l}-0.152^{* * *} \\
(0.038)\end{array}$ & & $\begin{array}{l}-0.136^{* * *} \\
(0.040)\end{array}$ \\
\hline Fin. dep. & & $\begin{array}{l}0.218^{* * *} \\
(0.071)\end{array}$ & & $\begin{array}{l}0.218^{* * *} \\
(0.071)\end{array}$ \\
\hline Firm-level controls & yes & yes & yes & yes \\
\hline Local trends & yes & yes & yes & yes \\
\hline Global trends & yes & yes & yes & yes \\
\hline$R^{2}$ & 0.021 & 0.061 & 0.041 & 0.063 \\
\hline $\mathrm{N}$ & 4,841 & 4,737 & 4,720 & 4,616 \\
\hline
\end{tabular}

Table A.24: Acceleration of RTFP Growth

\begin{tabular}{|c|c|c|c|c|c|c|}
\hline \multirow[b]{3}{*}{ Time trend } & \multicolumn{6}{|c|}{ Cumulative RTFP Growth } \\
\hline & $(1)$ & $(2)$ & $(3)$ & (4) & $(5)$ & (6) \\
\hline & $\begin{array}{l}17.586^{* * *} \\
(0.630)\end{array}$ & $\begin{array}{l}13.884^{* * *} \\
(0.537)\end{array}$ & $\begin{array}{l}13.523^{* * *} \\
(0.601)\end{array}$ & $\begin{array}{l}14.468^{* * *} \\
(3.319)\end{array}$ & $\begin{array}{l}13.845^{* * *} \\
(1.019)\end{array}$ & $\begin{array}{l}13.625^{* * *} \\
(0.574)\end{array}$ \\
\hline $\begin{array}{l}\text { Structural break in slope } \\
\text { (financial liberalization, 2001) }\end{array}$ & & $\begin{array}{l}8.992^{* * *} \\
(1.120)\end{array}$ & $\begin{array}{l}8.407^{* * *} \\
(1.194)\end{array}$ & $\begin{array}{l}9.115^{* * *} \\
(1.351)\end{array}$ & $\begin{array}{l}8.897^{* * *} \\
(2.368)\end{array}$ & $\begin{array}{l}11.083^{* * *} \\
(2.100)\end{array}$ \\
\hline $\begin{array}{l}\text { Structural break in level } \\
\text { (financial liberalization, 2001) }\end{array}$ & & & $\begin{array}{l}7.015 \\
(5.620)\end{array}$ & & & \\
\hline $\begin{array}{l}\text { Structural break in slope } \\
\text { (trade liberalization, 1996) }\end{array}$ & & & & $\begin{array}{l}-0.673 \\
(3.769)\end{array}$ & & \\
\hline $\begin{array}{l}\text { Structural break in slope } \\
\text { (falsification test, 1998) }\end{array}$ & & & & & $\begin{array}{l}0.116 \\
(2.527)\end{array}$ & \\
\hline $\begin{array}{l}\text { Structural break in slope } \\
\text { (falsification test, 2004) }\end{array}$ & & & & & & $\begin{array}{l}-3.513 \\
(2.999)\end{array}$ \\
\hline$R^{2}$ & 0.981 & 0.997 & 0.997 & 0.997 & 0.997 & 0.997 \\
\hline $\mathrm{N}$ & 17 & 17 & 17 & 17 & 17 & 17 \\
\hline
\end{tabular}

Notes: All regressions include a constant term. ${ }^{* * *},{ }^{* * *}$ significant at the $10,5,1$ percent level. Source: APEH. 


\section{Appendix B Model: Additional Derivations and Extensions}

\section{B.1. Additional Derivations}

(i) Firms' Markups and Profits. In the first period, firms make two types of decisions. First, they decide their optimal innovation efforts. Next, after learning the result of the innovation process, they decide whether to produce in the second period. I solve firms' optimal innovation efforts by backward induction. That is, I first compute firms' production profits and then compute their optimal innovation efforts.

In this Bertrand competition setting, only the firm with the lowest marginal cost in each intermediate variety will be active in equilibrium. Given the production function and the market structure, the active firm minimizes its total production cost:

$$
\begin{gathered}
\operatorname{Min}_{l_{s j t+1}, k_{s j t+1}} \quad T C_{s j t+1}=w_{t+1} l_{s j t+1}+R_{t+1}^{s^{\prime}} k_{s j t+1} \\
\text { st } \quad y_{s j t+1} \geq q_{s j t+1} k_{s j t+1}^{\alpha} l_{s j t+1}^{1-\alpha}
\end{gathered}
$$

where $R^{s^{\prime}}$ is either the domestic lending rate for home firms $\left(R^{L}\right)$ or the international rate $\left(R^{*}\right)$ otherwise. In variety $j$, the active firm's marginal cost becomes

$$
M C_{s j t+1}=\frac{1}{q_{s j t+1}}\left(\frac{R_{t+1}^{s^{\prime}}}{\alpha}\right)^{\alpha}\left(\frac{w_{t+1}}{1-\alpha}\right)^{1-\alpha} .
$$

Equation (18) indicates that the active firm's marginal cost depends on its productivity level and, notably, on its financing costs. The higher is the interest rate, the higher is its marginal cost. Given the optimal demand for variety $j, y_{j t+1}=\frac{Y_{t+1}}{p_{j t+1}}$, the active firm's profit from production activities is $\Pi_{j t+1}^{p}=\left(p_{j t+1}-M C_{j t+1}\right) y_{j t+1}=\left(1-\xi_{j t+1}^{-1}\right) Y_{t+1}$, where $\xi_{j t+1}$ is the firm's markup. I next turn to show how foreign and domestic firms' markups and profits are determined in equilibrium.

$\rightarrow$ Foreign firms. If the foreign firm in variety $j$ succeeds in improving the existing technology and is the market leader in equilibrium, its markup will be

$$
\xi_{F j t+1}^{p o s t} \equiv \frac{p_{j t+1}}{M C_{F j t+1}^{p o s t}}=\frac{M C_{H j t+1}^{p r e}}{M C_{F j t+1}^{p o s t}}=\left(\frac{R_{t+1}^{L}}{R_{t+1}^{*}}\right)^{\alpha} \frac{q_{F j t+1}^{\text {post }}}{q_{H j t+1}^{p r e}}=\tau_{t+1} \lambda^{\Delta_{j}+1},
$$

where $M C_{F j t+1}^{p o s t}$ is the foreign firm's marginal cost if the innovation succeeds, and $M C_{H j t+1}^{p r e}$ is the home firm's marginal cost in the absence of innovation. Recall that under Bertrand competition, the leader sets its price equal to the marginal cost of the closest competitor. In this case, the foreign firm sets its price equal to the marginal cost of the home firm in that variety. Notice that, after minimizing production costs, firms' marginal costs are given by $M C_{F j t+1}^{\text {post }}=\frac{\left(\frac{R_{t+1}^{*}}{\alpha}\right)^{\alpha}\left(\frac{w_{t+1}}{1-\alpha}\right)^{1-\alpha}}{q_{F j t+1}^{\text {post }}}$ and $M C_{H j t+1}^{p r e}=\frac{\left(\frac{R_{t+1}^{L}}{\alpha}\right)^{\alpha}\left(\frac{w_{t+1}}{1-\alpha}\right)^{1-\alpha}}{q_{H j t+1}^{p r e}}$. 
If the foreign firm does not succeed in improving the existing technology and keeps its initial productivity level, its markup will be

$$
\xi_{F j t+1}^{p r e} \equiv \frac{p_{j t+1}}{M C_{F j t+1}^{p r e}}=\frac{M C_{H j t+1}^{p r e}}{M C_{F j t+1}^{p r e}}=\left(\frac{R_{t+1}^{L}}{R_{t+1}^{*}}\right)^{\alpha} \frac{q_{F j t+1}^{p r e}}{q_{H j t+1}^{p r e}}=\tau_{t+1} \lambda^{\Delta_{j}} .
$$

Given equations (19) and (20), the foreign firm's post- and pre-innovation profits are

$$
\Pi_{F j t+1}^{p o s t}=\left(1-\frac{1}{\tau_{t+1} \lambda^{\Delta_{j}+1}}\right) Y_{t+1} \quad \text { and } \quad \Pi_{F j t+1}^{p r e}=\left(1-\frac{1}{\tau_{t+1} \lambda^{\Delta_{j}}}\right) Y_{t+1}
$$

Equations (19)-(21) show that if foreign firms are active in equilibrium, their markups and profits are distorted by $\tau_{t+1}=R_{t+1}^{L} / R_{t+1}^{*}$, namely the differential access to capital markets.

$\rightarrow$ Home firms. If the home firm in variety $j$ succeeds in improving the existing technology and becomes the market leader, its markup will be

$$
\xi_{H j t+1}^{p o s t} \equiv \frac{p_{j t+1}}{M C_{H j t+1}^{p o s t}}=\frac{M C_{F j t+1}^{p r e}}{M C_{H j t+1}^{p o s t}}=\left(\frac{R_{t+1}^{*}}{R_{t+1}^{L}}\right)^{\alpha} \frac{q_{H j t+1}^{\text {post }}}{q_{F j t+1}^{\text {pre }}}=\frac{\lambda}{\tau_{t+1}} .
$$

Otherwise, it will still have a higher marginal cost than a foreign firm and remain out of the market. The home firm's post-innovation profit will be

$$
\Pi_{H j t+1}^{p o s t}=\left(1-\frac{\tau_{t+1}}{\lambda}\right) Y_{t+1}
$$

As for foreign firms, equations (22) and (23) show that home firms' markups and profits are distorted by asymmetric access to international capital markets. Notice that, in equations (19)-(23), the technology gap between foreign and home firms is the only variety-specific payoff-relevant variable. To simplify notation, I drop the dependence on variety $j$ and denote each variety as a function of the productivity gap. Note that the revenue TFP of the active producer becomes $R T F P_{s \Delta t+1}=\left[\left(\frac{w_{t+1}}{1-\alpha}\right)^{1-\alpha}\left(\frac{R_{t+1}^{s^{\prime}}}{\alpha}\right)^{\alpha}\right] \xi_{s \Delta t+1}$.

(ii) Firms' Innovation Efforts. Firms choose their optimal innovation efforts, $x_{F \Delta t}$ and $x_{H \Delta t}$, so as to maximize their expected profits net of the innovation costs. Given the research technology, 
the optimization programs of foreign and home firms $\operatorname{are}^{34}$

$$
\begin{gathered}
\operatorname{Max}_{x_{F \Delta t}} x_{F \Delta t} \Pi_{F \Delta t+1}^{\text {post }}+\left(1-x_{F \Delta t}-x_{H \Delta t}\right) \Pi_{F \Delta t+1}^{p r e}-R_{t+1}^{*}\left[w_{t} \Gamma\left(x_{F \Delta t}, \Delta\right)\right] \\
\text { and } \operatorname{Max}_{x_{H \Delta t}} x_{H \Delta t} \Pi_{H \Delta t+1}^{p o s t}-R_{t+1}^{L}\left[w_{t} \Gamma\left(x_{H \Delta t}\right)\right] .
\end{gathered}
$$

Firms' optimal innovation efforts become

$$
x_{F t}=\frac{\phi}{\tau_{t+1}} \frac{\left(1-\lambda^{-1}\right)}{w_{t}} \frac{Y_{t+1}}{R_{t+1}^{*}} \quad \text { and } \quad x_{H t}=\frac{\phi}{\tau_{t+1}^{1 / \alpha}} \frac{\left(1-\tau_{t+1} \lambda^{-1}\right)}{w_{t}} \frac{Y_{t+1}}{R_{t+1}^{*}} .
$$

As discussed above, both firms' optimal innovation intensities are distorted by the asymmetric access to international capital markets. Furthermore, firms' innovation intensities are constant across varieties and only differ in their borrowing costs $(\tau)$; hence, if firms enjoyed similar access to capital markets, their innovation efforts would be equal.

(iii) Aggregate Productivity Growth. Aggregate productivity growth is given by

$$
g_{Q t+1}=\log (\lambda)\left(x_{F t}+x_{H t}\right) .
$$

To see this, note that the aggregate productivity level is $\log \left(Q_{t+1}\right)=\int_{0}^{1} \log \left(q_{j t+1}\right) d j$. In each intermediate variety, productivity increases originate from two sources: either the domestic firm innovates with probability $x_{H t}$ or the foreign firm innovates with probability $x_{F t}$. In both cases, productivity increases by a factor $\log (\lambda)$. Therefore, the increase in productivity in each variety is $x_{H t} \log (\lambda)+x_{F t} \log (\lambda)$. Under the law of large numbers, a continuum of varieties of measure one ensures that the change in aggregate productivity is given by $\left(x_{H t}+x_{F t}\right) \log (\lambda)$ and that its level in $t+1$ is $\log \left(Q_{t+1}\right)=\left(x_{H t}+x_{F t}\right) \log (\lambda)+\log \left(Q_{t}\right)$. As a result, aggregate productivity growth is given by

$$
g_{Q t+1}=\log \left(Q_{t+1}\right)-\log \left(Q_{t}\right)=\log (\lambda)\left(x_{H t}+x_{F t}\right) .
$$

(iv) Labor Market Clearing. After minimizing its total costs, the optimal labor demand of the active firm producing in variety $\Delta$ is $l_{\Delta t+1}=(1-\alpha) \frac{Y_{t+1}}{w_{t+1}} \frac{1}{\xi_{\Delta t+1}^{\text {end }}}$, where end denotes the obtained markups, which can be either post if the firm succeeded in innovating or pre otherwise. Aggregating across varieties, the total labor demand for production activities is $L_{t+1}^{p}=(1-\alpha) \frac{Y_{t+1}}{w_{t+1}} \Lambda_{t+1}$, where $\Lambda_{t+1}=\int \xi_{\Delta t+1}^{-1 e n d} d \Delta<1$ as in Peters (2013). Note that the labor demand is reduced by the

\footnotetext{
${ }^{34}$ For simplicity, I assume that firms borrow from banks once they learn about the result of the innovation process, and hence there is no uncertainty in the debt contract. This assumption allows us to focus on firms' pure incentives to innovate and separate these decisions from optimal debt contracts. As is standard in innovation models, it implies that workers are able to insure against innovation risk. For example, this could be implemented through a mutual fund consisting of a continuum of risk-neutral workers. After being paid, workers deposit their wage payments in the fund and divide them equally between themselves (as in Acemoglu 2009; Aghion and Howitt 1992; Peters 2013).
} 
presence of markups, as active firms set higher prices, produce less, and, hence, demand less labor. Labor market clearing implies $L_{t+1} \equiv 1=L_{t+1}^{p}+L_{t+1}^{I}$, where $L^{I}$ represents the labor employed in innovation activities by the new firms in $t+1$, and $L_{t+1}^{I}=\int \Gamma\left(x_{s t}\right) d \Delta$. This determines the equilibrium wage in the economy.

(v) Capital Market Clearing. After minimizing its costs, the optimal capital demand of the active firm producing in variety $\Delta$ is $k_{s \Delta t+1}=\frac{\alpha}{R_{t+1}^{s^{\prime}}} \frac{Y_{t+1}}{\xi_{\Delta t+1}^{\text {end }}}$, where $R_{t+1}^{s^{\prime}}$ is either the domestic lending rate if a home firm is active in equilibrium or the international rate otherwise. Aggregating across varieties, the total capital demands of home and foreign firms are

$$
K_{t+1}^{H}=\frac{\alpha}{R_{t+1}^{L}} Y_{t+1} \Lambda_{t+1}^{H} \quad \text { and } \quad K_{t+1}^{F}=\frac{\alpha}{R_{t+1}^{*}} Y_{t+1} \Lambda_{t+1}^{F},
$$

where $\Lambda_{t+1}^{H}=\int \xi_{H t+1}^{-1} d H<1$ and $\Lambda_{t+1}^{F}=\int \xi_{F \Delta t+1}^{-1} d F<1$ and denote the distribution of markups of active domestic and foreign firms. Similarly to labor demands, firms' optimal capital demands are reduced by markups, as they reduce the optimal scale of production. Foreign firms invest capital until the return of their investment is equal to the international interest rate. As there are no financial flows in or out of the economy, home firms' total investment equals the local savings of young workers.

(vi) Budget Constraint in the Closed Economy. The economy's budget constraint is given by

$$
C_{t+1}+I_{t+1}^{H}+I_{t+1}^{F}=w_{t+1} L_{t+1}^{p}+\Pi_{t+1}^{H}+\Pi_{t+1}^{F}+R_{t+1}^{D} K_{t+1}^{H}+R_{t+1}^{*} K_{t+1}^{F},
$$

where investment $\left(I_{t+1}^{s}\right)$ includes investment in the capital and technology of active firms. Aggregate consumption and investment equal the wages of workers employed by domestic and foreign firms, net profits of active domestic and foreign firms, and payments to home and foreign capital. ${ }^{35}$ The balance of payments implies that the current account (CA) and capital account (KA) sum to zero and, in particular, that foreign firms' net profits and capital repayment (capital outflows) equal their investment (capital inflows):

$$
C A_{t+1}-K A_{t+1}=0 \quad \Leftrightarrow \quad-\left[\Pi_{t+1}^{F}+R_{t+1}^{*} K_{t+1}^{F}\right]+I_{t+1}^{F}=0 .
$$

(vii) Budget Constraint and Equilibrium in the Open Economy. Since in the open economy, local investment is no longer constrained by the availability of domestic savings, the expansion of home firms leads to capital inflows. The economy's budget constraint becomes

$C_{(t+1)}+\hat{I}_{(t+1)}^{H}+\hat{I}_{(t+1)}^{F}=w_{(t+1)} L_{(t+1)}^{p}+\Pi_{(t+1)}^{H}+\Pi_{(t+1)}^{F}+T_{(t+1)}+\left(R_{(t+1)}^{*}+\hat{\tau}\right) \hat{K}_{(t+1)}^{H}+R_{(t+1)}^{*} \hat{K}_{(t+1)}^{F}$,

\footnotetext{
${ }^{35}$ Since the economy is shut down to international financial flows, lump-sum transfers to domestic households are zero.
} 
where consumption and investment equal the payments of workers employed in production activities, home and foreign firms' net profits, lump-sum transfers and payments to home and foreign capital. The balance of payments is now defined as

$$
C A_{(t+1)}-K A_{(t+1)}=0 \quad \Leftrightarrow \quad-\left[\Pi_{(t+1)}^{F}+R_{(t+1)}^{*}\left(\hat{K}_{(t+1)}^{F}+\hat{K}_{(t+1)}^{H *}\right)\right]+\left(\hat{I}_{(t+1)}^{F}+\hat{I}_{(t+1)}^{H *}\right)=0,
$$

where $\hat{K}_{(t+1)}^{H *}$ and $\hat{I}_{(t+1)}^{H *}$ denote home investment financed with international funds. The current account deficit expands as the increase in aggregate investment exceeds the expansion of local savings.

In the open economy equilibrium, banks earn zero profits at $\hat{R}_{t+1}^{L}$ and $\hat{R}_{t+1}^{D}$; firms' innovation intensities are given by (4); active firms in each variety set the price equal to the marginal cost of the closest competitor; labor and capital markets clear; aggregate output is given by $Y_{t+1}$; aggregate consumption is the sum of old workers' consumption; the economy growth rate is $g_{Y t+1}$; and the balance of payments is determined by $-\left[\Pi_{t+1}^{F}+R_{t+1}^{*}\left(\hat{K}_{t+1}^{F}+\hat{K}_{t+1}^{H *}\right)\right]+\left(\hat{I}_{t+1}^{F}+\hat{I}_{t+1}^{H *}\right)=0$, where $\hat{K}_{t+1}^{H *}$ and $\hat{I}_{t+1}^{H *}$ denote home investment financed with international funds. The increase in capital inflows induces a deterioration in the current account. 


\section{B.2. Banks and the Direction of Capital Flows}

This section discusses banks' optimal lending and financing choices in an economy subject to capital controls. Consider that capital controls are such that only local banks are allowed to intermediate foreign funds, but they incur a cost. As in Farhi and Werning (2012), capital controls take the form of a per unit tax. In particular, banks have to pay a tax $\tilde{\tau}$ per unit of foreign borrowing or lending, which is then redistributed lump-sum to local households. In this economy, banks have two financing choices and two lending choices: they can use either local or foreign savings to finance their activities, and they can lend to either local or foreign agents. Importantly, the level of capital controls determines banks' intermediation choices and, with them, whether the economy is open or closed to financial flows and its level of international financial integration.

More precisely, to finance their activities, banks can either borrow from domestic agents and pay the deposit rate $R_{t+1}^{D}$ or borrow foreign savings and pay the international interest rate plus the per unit tax, i.e. $R_{t+1}^{*}+\tilde{\tau}$. Similarly, banks enjoy two lending choices: they can either lend to home firms at the rate $R_{t+1}^{L}$ or pay the tax on foreign transactions and lend abroad for a net return of $R_{t+1}^{*}-\tilde{\tau}$. In this way, banks' international financial transactions depend on how the domestic deposit and lending interest rates compare with the foreign rate and the tax.

In this economy, two thresholds determine whether banks find it profitable to intermediate foreign funds. One threshold defines banks' financing choices, and a second threshold determines banks' lending choices. The first threshold is given by the comparison between $R_{t+1}^{D}$ and $R_{t+1}^{*}+\tilde{\tau}$, which establishes whether the domestic deposit interest rate is higher or lower than the foreign rate plus the tax. If the domestic deposit rate is higher than the international rate plus the tax on foreign transactions, banks' financing costs are cheaper abroad than in the local economy and, hence, they prefer to finance their activities using foreign savings. Importantly, as the return from lending abroad is lower than the local lending rate, $R_{t+1}^{L}-\mu>R_{t+1}^{*}+\tilde{\tau}$, banks do not lend abroad and focus their lending activities in the local market. Therefore, banks use foreign savings to finance their local activities. In this case, financial liberalization leads banks to import foreign funds until the local deposit rate is equal to the foreign interest rate plus the tax, and they become indifferent between using local or foreign savings. This is the equilibrium in which the economy receives capital inflows.

The second threshold is given by $R_{t+1}^{L}-\mu<R_{t+1}^{*}-\tilde{\tau}$, which defines that the local net lending rate is lower than the return that banks would obtain from lending abroad. In this case, banks would prefer to lend to foreign agents, as the return from lending locally is lower than what they would obtain if they lend abroad. It is worth remarking that banks finance themselves using local savings only because the local deposit rate is lower than the cost of using foreign savings, i.e. $R_{t+1}^{D}<R_{t+1}^{*}+\tilde{\tau}$. As such, financial liberalization leads banks to finance themselves locally and use home savings to lend to foreign agents. Since banks use local savings to lend internationally, there are capital outflows from the economy. The lesser amount of savings available for domestic firms increases the domestic lending rate until it is equal to the international rate minus the tax, and banks become indifferent between lending locally or abroad. This is the equilibrium in which 
the economy experiences capital outflows.

Importantly, if the tax rate is high enough, banks' optimal choice is to collect local savings to lend to home firms. In particular, for a sufficiently large $\tilde{\tau}, R_{t+1}^{L}>R_{t+1}^{*}-\tilde{\tau}$, and banks only lend to local agents, and $R_{t+1}^{D}-\mu<R_{t+1}^{*}+\tilde{\tau}$ such that banks only finance their lending activities using local deposits. As such, banks' lending and financing activities remain local whenever the equilibrium domestic deposit rate falls between $R_{t+1}^{*}-\tilde{\tau}-\mu<R_{t+1}^{D}<R_{t+1}^{*}+\tilde{\tau}$.

These two thresholds determine three regimes under which the economy could function: 1) if $R_{t+1}^{D}>R_{t+1}^{*}+\tilde{\tau}$, the economy receives capital inflows; 2) if $R_{t+1}^{L}-\mu<R_{t+1}^{*}-\tilde{\tau}$, the economy experiences capital outflows; and 3) if $R_{t+1}^{*}-\tilde{\tau}<R_{t+1}^{D}<R_{t+1}^{*}+\tilde{\tau}$, the economy is closed to international financial flows. These three regimes are presented in the following table.

\section{Capital Controls and International Capital Flows}

\begin{tabular}{lll}
\hline \hline Condition on $R^{D}$ & Banks' Optimal Behavior & International Capital Flows \\
\hline$R_{t+1}^{D}>R_{t+1}^{*}+\tilde{\tau}$ & Use foreign savings to lend locally & Capital inflows \\
$R_{t+1}^{D}<R_{t+1}^{*}-\tilde{\tau}$ & Use local savings to lend abroad & Capital outflows \\
$R_{t+1}^{*}-\tilde{\tau}<R_{t+1}^{D}<R_{t+1}^{*}+\tilde{\tau}$ & Use local savings to lend locally & Closed economy \\
\hline \hline
\end{tabular}

I formally derive banks' optimal choices below and show that only these three equilibria are possible in this framework.

\section{Banks' Optimal Financing and Lending Choices}

To formally study banks' optimal lending and financing decisions, recall that banks operate in a perfectly competitive sector and, hence, choose their optimal level of lending and deposits from local and international markets. Banks' optimization program is as follows:

$$
\begin{gathered}
\operatorname{Max}_{\left\{L_{t+1}^{H}, D_{t+1}^{H}, L_{t+1}^{*}, D_{t+1}^{*}\right\}} R_{t+1}^{L} L_{t+1}^{H}+\left(R_{t+1}^{*}-\tilde{\tau}\right) L_{t+1}^{*}-R_{t+1}^{D} D_{t+1}^{H}-\left(R_{t+1}^{*}+\tilde{\tau}\right) D_{t+1}^{*}-\mu L_{t+1}^{H}-\mu L_{t+1}^{*} \\
\text { st } \quad L_{t+1}^{H}+L_{t+1}^{*}=D_{t+1}^{H}+D_{t+1}^{*}, \\
L_{t+1}^{*} \geq 0 \\
D_{t+1}^{*} \geq 0 \\
L_{t+1}^{H}>0, D_{t+1}^{H}>0
\end{gathered}
$$

where $L_{t+1}^{H}, D_{t+1}^{H}, L_{t+1}^{*}, D_{t+1}^{*}$ represent the lending and deposits in the local and foreign markets, respectively. Using equation (27), banks' optimal maximization program becomes 


$$
\begin{gathered}
L=R_{t+1}^{L} L_{t+1}^{H}+\left(R_{t+1}^{*}-\tilde{\tau}\right)\left(D_{t+1}^{H}+D_{t+1}^{*}-L_{t+1}^{H}\right)-R_{t+1}^{D} D_{t+1}^{H}-\left(R_{t+1}^{*}+\tilde{\tau}\right) D_{t+1}^{*}- \\
\mu L_{t+1}^{H}-\mu L_{t+1}^{*}-\lambda_{1}\left(L_{t+1}^{H}-D_{t+1}^{H}-D_{t+1}^{*}\right)-\lambda_{2}\left(-D_{t+1}^{*}\right) .
\end{gathered}
$$

\section{Case 1: Closed-Economy Equilibrium}

If $\lambda_{1}>0$ and $\lambda_{2}>0$, equations (27) and (28) bind. The first order conditions for banks' optimal level of domestic lending and deposits imply that the domestic lending rate is equal to the domestic deposit rate plus the intermediation costs:

$$
R_{t+1}^{L}=R_{t+1}^{D}+\mu
$$

and that the total level lending equals total deposits in the domestic market:

$$
L_{t+1}^{H}=D_{t+1}^{H} .
$$

This is a closed-economy equilibrium, with no international financial flows, as discussed in Sections 2.1-2.3.

\section{Case 2: Capital Inflows Equilibrium}

If $\lambda_{1}>0$ and $\lambda_{2}=0$, then $L_{t+1}^{*}=0$ and $D_{t+1}^{*}>0$. The first order conditions for $L^{H}, D^{H}$, and $D^{*}$ imply that

$$
L_{t+1}^{H}=D_{t+1}^{H}+D_{t+1}^{*},
$$

which shows that banks employ both domestic and foreign savings to finance their local lending activities. The domestic lending and deposit rates are given by

$$
R_{t+1}^{D}=R_{t+1}^{*}+\tilde{\tau} \quad \text { and } \quad R_{t+1}^{L}=R_{t+1}^{*}+\tilde{\tau}+\mu=R_{t+1}^{D}+\mu .
$$

In this equilibrium, there are capital inflows into the economy.

\section{Case 3: Capital Outflows Equilibrium}

If $\lambda_{1}>0$ and $\lambda_{2}=0$, then $L_{t+1}^{*}>0$ and $D_{t+1}^{*}=0$. Banks' optimal decisions on $L^{H}, D^{H}$, and $L^{*}$ imply that

$$
L_{t+1}^{H}+L_{t+1}^{*}=D_{t+1}^{H} .
$$

That is, banks only employ domestic deposits to finance their lending activities that are oriented to both the local and foreign markets. In this equilibrium, the domestic and lending rates are given by

$$
R_{t+1}^{L}=R_{t+1}^{*}-\tilde{\tau}+\mu \quad \text { and } \quad R_{t+1}^{D}=R_{t+1}^{*}-\tilde{\tau} .
$$


In this equilibrium, there are capital outflows out of the economy.

\section{Case 4: No Equilibrium}

Notice that if $\lambda_{1}=0$ and $\lambda_{2}=0$ (i.e. $L_{t+1}^{*}>0$ and $D_{t+1}^{*}>0$ ), an equilibrium does not exist, as neither $\tilde{\tau}$ nor $\mu$ can take negative values in this framework. 


\section{B.3. Financial Liberalization: Comparative Statics}

Proposition 1. $\frac{\partial x_{F t}}{\partial \tau_{t+1}}<0$ and $\frac{\partial x_{H t}}{\partial \tau_{t+1}}<0$. This can be directly seen from equation (4). Furthermore, $\left|\frac{\partial x_{F t}}{\partial \tau_{t+1}}\right|<\left|\frac{\partial x_{H t}}{\partial \tau_{t+1}}\right|$.

Proposition 2. Active domestic firms' leverage $\left(d / y_{H t+1}^{p o s t}=w_{t} \frac{\Gamma\left(x_{H t}\right)}{y_{H t+1}}+\frac{k_{H t+1}}{y_{H t+1}}\right)$ is given by ${ }^{36}$

$$
\left\{\begin{array}{lc}
(d / y)_{H \Delta t+1}^{\text {post }} & \text { with probability } x_{H t} \\
0 & \text { otherwise. }
\end{array}\right.
$$

Under the law of large numbers, a continuum of varieties guarantees that a domestic firm's leverage equals its expected value, i.e.

$$
(d / y)_{H \Delta t+1}^{e}=(d / y)_{H \Delta t+1}^{p o s t} x_{H t}
$$

Then, $\frac{\partial(d / y)_{H \Delta t+1}^{e}}{\partial \tau_{t+1}}<0$.

Proposition 3. As equation (2) shows, foreign firms' markups originate from two sources: the technology gap between their local competitors and the difference in financing terms. Both of them decrease in $\tau$. To see this, consider first how the reduction in distortions in international capital markets affects the technology gap between foreign and home firms. Notice that the technology gap between foreign and home firms within a variety will be

$$
\left\{\begin{array}{lll}
\Delta+1 & \text { with probability } & x_{F t}, \\
-1 & \text { with probability } & x_{H t}, \\
\Delta & \text { with probability } & \left(1-x_{F t}-x_{H t}\right) .
\end{array}\right.
$$

Under the law of large numbers, the expected technology gap between $\mathrm{F}$ and $\mathrm{H}$ firms $\Delta^{e}$ becomes

$$
\Delta_{t+1}^{e}=\Delta+x_{F t}-(1+\Delta) x_{H t}
$$

As $\frac{\partial \Delta_{t+1}^{e}}{\partial \tau_{t+1}}>0$, reductions in distortions in capital markets reduce the productivity gap between foreign and home firms. Furthermore, a foreign firm's markup will be

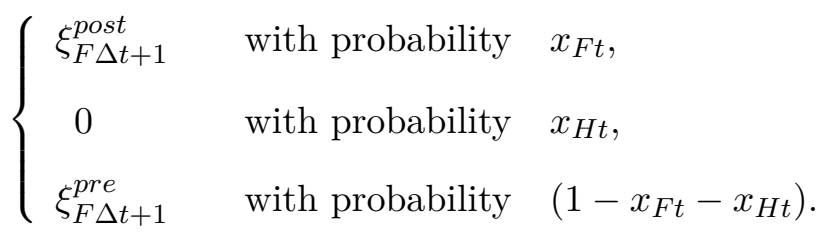

${ }^{36}$ To simplify notation, I have dropped the dependence on variety $j$ and denote each intermediate variety as a function of the productivity gap, which is the only variety-specific payoff-relevant variable (see equation (2)). 
Under the law of large numbers, a continuum of varieties ensures that a foreign firm's markup will be equal to its expected value. More precisely,

$$
\xi_{F \Delta t+1}^{e}=\tau_{t+1} \lambda^{\Delta+1} x_{F t}+\tau_{t+1} \lambda^{\Delta}\left(1-x_{F t}-x_{H t}\right) .
$$

Using equations (31) and (33), the change in foreign firms' expected markups is

$$
\frac{\partial \xi_{F \Delta t+1}^{e}}{\partial \tau_{t+1}}=\underbrace{\lambda^{\Delta}\left(1+x_{F t}(\lambda-1)-x_{H t}\right)\left(1+\tau_{t+1} \ln (\lambda) \frac{\partial \Delta_{t+1}^{e}}{\partial \tau_{t+1}}\right)}_{>0}+\underbrace{\tau_{t+1} \lambda^{\Delta}\left((\lambda-1) \frac{\partial x_{F t}}{\partial \tau_{t+1}}-\frac{\partial x_{(H, t)}}{\partial \tau_{t+1}}\right)}_{>0}>0 .
$$

Therefore, foreign firms' markups decrease following the reduction in distortions in the access to international capital markets.

Proposition 4. From equation (31), it can be directly seen that $\frac{\partial \Delta_{t+1}^{e}}{\partial \tau_{t+1} \partial \Delta}>0$.

Proposition 5. The sign of $\frac{\partial g_{Q t+1}}{\partial \tau_{t+1}}$ results directly from Proposition 1 and equation (5). 


\section{B.4. Financial Liberalization: General Equilibrium}

This section conducts a numerical experiment to illustrate the model's qualitative implications of Section 2.4.2 in a general equilibrium framework. Note that this exercise does not aim to quantify the model, but rather to provide some insights about whether its qualitative predictions hold true in general equilibrium.

\section{-Numerical Illustration}

In this exercise, I study the impact of a reduction in capital controls on firms' innovation incentives, competition, and aggregate productivity growth in general equilibrium when financial liberalization leads to capital inflows. In the model, the level of capital controls is given by $\hat{\tau}$, which represents the wedge between the domestic and international interest rate. In this experiment, I set its initial level to $3 \%$, which was the interest rate differential between domestic and foreign firms prior to the reform (Table 1), and I let this parameter go to 0 as we move from the regulated to the liberalized economy. I let the international interest rate $R^{*}$ be $5.15 \%$, which was the level of a U.S. one-year T-bill in 2000. To better visualize the results, I consider a small wedge in the level of financial development of the country and let $\mu$ be $0.1 \%$ and keep it constant along the exercise. I let the elasticity of capital be 1/3. Following the standard literature in innovation (Acemoglu, Aghion, and Zilibotti 2006, and Acemoglu and Akcigit 2011, among others), I choose $\lambda$ and the technology parameter $\phi$ to match the aggregate productivity growth in Hungary prior to the reform $(5.8 \%$ per year, as shown in Table 12). I then let $\lambda=1.2$ and $\phi=0.3$. The equilibrium employment of $\mathrm{R} \& \mathrm{D}$ workers depends on the largest productivity gap between domestic and foreign firms, i.e. parameter $d$. I use the analysis in Section 5.5 to recover this parameter from the data. In particular, I compute the productivity gap as the RTFP gap between the median foreign and domestic firms within three-digit sectors and find that the larger gap prior to the reform was 2.5, so I set $d$ equal to this value. The estimation of domestic firms' leverage requires considering two initial values: the level of aggregate TFP and the productivity level of the home firm. I take both values from the data and estimate $\ln Q^{\text {initial }}=8.716$ and $\ln q^{H}=1.19$, where the latter is the mean RTFP of home firms in Table 2. Finally, the estimation of foreign firms' markups and the productivity gap within sectors require setting the value of the initial productivity gap between foreign and home firms. I estimate an initial productivity gap of one.

Figure B.4.1 shows that all the model's qualitative implications hold in a general equilibrium setting. The horizontal axis represents the level of capital controls, i.e. the parameter $\hat{\tau}$ in the model, which goes from -0.03 under capital controls to 0 in the liberalized economy. Figure B.4.1 illustrates that a reduction in capital controls raises all firms' incentives to invest in technology. In line with Proposition 1, this expansion is greater for home firms. As expected, domestic firms' leverage also increases following the liberalization of capital flows (Proposition 2). Confirming the presence of pro-competitive forces, the reduction in capital controls is also associated with a decrease in foreign firms' markups and with reductions in the productivity gap between foreign and domestic firms (Propositions 3 and 4). The increase in aggregate productivity growth (Proposition 

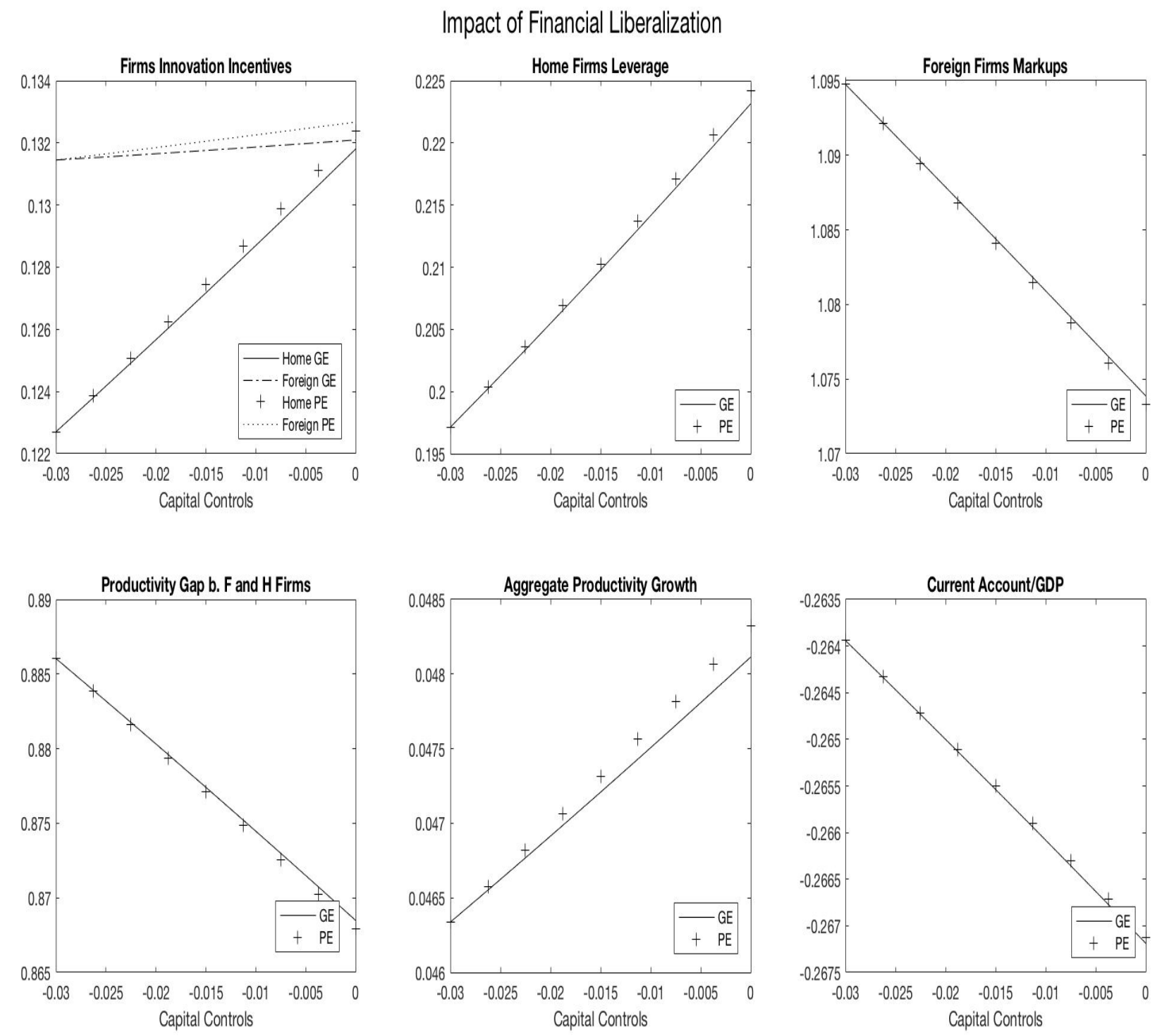

Figure B.4.1: The Impact of Financial Liberalization in GE

5) is also valid in a general equilibrium setting. Additionally, I have included the evolution of the current account, the deterioration of which is in line with the increase in capital inflows following the financial liberalization.

For comparison, I include in Figure B.4.1 the results of the partial equilibrium analysis of Section 2.4, where wages and aggregate output are held constant. That is, I compare how a reduction in capital controls affects firms' investment in technology and competition when wages and aggregate output are held constant or allowed to adjust. As expected, in general equilibrium, the expansion in firms' innovation efforts is relatively smaller because the increase in wages raises the innovation costs (see Atkeson and Burstein 2010). 


\section{B.5. Financial Liberalization: Capital Outflows}

Consider a low level of financial development (high $\mu$ ) such that the reduction in capital controls makes the deposit interest rate lower than the foreign interest rate minus the new value of the tax rate $\hat{\tau}, R_{t+1}^{D}<R_{t+1}^{*}-\hat{\tau}$. In this case, banks prefer to lend to foreign agents because the domestic lending rate is lower than what banks would perceive if they lend abroad:

$$
R_{t+1}^{L}-\mu<R_{t+1}^{*}-\hat{\tau}
$$

Furthermore, banks finance themselves by employing local savings only because the local deposit rate is lower than the cost of employing foreign savings $\left(R_{t+1}^{D}<R_{t+1}^{*}+\hat{\tau}\right)$. Hence, under equation (34), banks finance themselves locally and use domestic savings to lend to foreign agents. Since banks use local savings to lend internationally, there are capital outflows from the economy. The lesser amount of savings available for domestic firms increases the domestic lending rate until it is equal to the international rate minus the tax and banks become indifferent between lending locally or abroad. In the open economy equilibrium, the domestic deposit and lending rates are exogenously determined by

$$
\hat{R}_{t+1}^{D}=R_{t+1}^{*}-\hat{\tau} \quad \text { and } \quad \hat{R}_{t+1}^{L}=R_{t+1}^{*}-\hat{\tau}+\mu
$$

It is worth noting that whether or not the economy experiences capital outflows depends on how the tax on foreign transactions compares with the local level of financial development $(\mu)$. In particular, the local intermediation cost creates a wedge between the domestic lending rate and the return to lend internationally. The larger is this wedge, the lower are banks' returns from lending locally and, hence, their incentives to intermediate funds domestically. Hence, as in Gertler and Rogoff (1990), Mendoza, Quadrini, and Rios-Rull (2009), and Coeurdacier, Guibaud, and Jin (2015), a low level of financial development can lead to capital outflows even in a capital-scarce economy.

Importantly, if the closed-economy lending rate satisfies equation (34), capital account liberalization leads to an increase in the costs of funds for domestic firms. Higher borrowing costs raise their marginal cost, undermining their post-innovation profits and their incentives to invest in technology. In turn, the lower competitive pressure in the product market reduces foreign firms' incentives to invest in technology. As both home and foreign firms innovate less, aggregate productivity grows at a lower pace after the liberalization. Note as well that the increase in the domestic lending rate reduces home firms' capital demands and, thus, their leverage and investment. In turn, the decline in aggregate investment leads to an improvement in the current account. 


\section{B.6. Pro-Competitive Effects in Cournot Competition}

This section analyses whether the pro-competitive effects implied in Bertrand competition following financial liberalization are also valid in other oligopolistic frameworks. To analyze this, I build a model in the spirit of Devereux and Lee (2001), Atkeson and Burstein (2008) and Edmond, Midrigan, and $\mathrm{Xu}$ (2015), who study the effects of trade liberalization in Cournot competition. I adapt these models to the case of financial liberalization and extend it to the case of endogenous innovation and asymmetric access to international capital markets across firms. I show that, in this setting, financial liberalization also turns on pro-competitive forces that lead all firms to invest more in technology. Previously discriminated home firms invest more in technology because they face better financing terms. Non-discriminated firms also invest more in technology because they face deeper competition.

\section{-Setup}

This model follows the same timing as in the main text. In the first period, intermediate firms make two types of decisions: first, they choose their optimal innovation efforts; next, after learning the result of the innovation process, they decide whether to produce in the second period. To produce in $t+1$, firms need to invest in physical capital in $t$. As in the main text, firms finance their expenditures in capital and technology with external funds and take the innovation efforts of other agents and factor prices as given. To keep the analysis simple, and since the purpose of this exercise is to illustrate the pro-competitive forces in a Cournot setting, I focus on a partial equilibrium economy. I first describe the setup and later present the qualitative implications of the model.

\section{Final Good}

There is a final good composed of a continuum of measure one of $j$ intermediate varieties:

$$
Y_{t+1}=\left(\int_{0}^{1} \frac{\theta-1}{\theta} y_{j+1}^{\theta} d j\right)^{\frac{\theta}{\theta-1}}
$$

where $\theta>1$ is the elasticity of substitution across varieties $j$. The aggregate price index is $P_{t+1}=$ $\left(\int_{0}^{1} p_{j t+1}^{1-\theta} d j\right)^{\frac{1}{1-\theta}}$. For simplicity, I allow each intermediate variety to be composed of two firms, home and foreign, and the intermediate output to be given by

$$
y_{j t+1}=\left(\beta \frac{\frac{\gamma-1}{\gamma}}{y_{H j t+1}^{\gamma}}+(1-\beta) y_{F j t+1}^{\frac{\gamma-1}{\gamma}}\right)^{\frac{\gamma}{\gamma-1}},
$$

where $\gamma>\theta$ is the elasticity of substitution across goods within a particular variety. The variety price index is $p_{j t+1}=\left(\beta p_{H j t+1}^{1-\gamma}+(1-\beta) p_{F j t+1}^{1-\gamma}\right)^{\frac{1}{1-\gamma}}$. Given equations (36) and (37), the final 
good producer's optimal demand functions are

$$
y_{H j t+1}=\left(\frac{p_{H j t+1}}{p_{j t+1}}\right)^{-\gamma}\left(\frac{p_{j t+1}}{P_{t+1}}\right)^{-\theta} Y_{t+1} \quad \text { and } \quad y_{F j t+1}=\left(\frac{p_{F j t+1}}{p_{j t+1}}\right)^{-\gamma}\left(\frac{p_{j t+1}}{P_{t+1}}\right)^{-\theta} Y_{t+1} .
$$

\section{Intermediate Varieties}

Capital Markets. Capital markets follow the same structure as in the main text. I assume that the economy is subject to capital controls, such that only local banks can intermediate foreign funds. However, banks have to pay a tax per unit of foreign borrowing or lending, i.e. $\tilde{\tau}$. This tax is then rebated as a lump sum to the domestic household. The intermediate financial sector is perfectly competitive, but incurs higher intermediation costs, $\mu$, than the rest of the world. There is asymmetric access to international capital markets across firms: whereas domestic firms can only borrow from local banks at a rate $R^{L}$, foreign firms have direct access to international funds and borrow at $R^{*}$. I follow the exercise in Section 2.4.2, where the economy is capital scarce and experiences capital inflows upon financial liberalization.

Production. Intermediate firm producers operate using a Cobb-Douglas production function $y_{s j}=$ $q_{s j} k_{s j}^{\alpha} l_{s j}^{1-\alpha}$, where $s=\{H, F\}, q, k, l$ represent physical productivity, capital, and labor, and $\alpha \in(0,1)$. Capital fully depreciates upon production.

Competition. In each intermediate variety, firms engage in Cournot competition and choose quantities $\left(y_{s j t+1}\right)$, taking as given the quantity decisions of their variety competitor.

Technology and Innovation. I let firms' productivity evolve in a quality ladder, with increases measured by $\lambda$. Research technology implies that innovation is stochastic and depends on firms' innovation efforts. In particular, $R \& D$ technology is such that if a firm aims for an innovation intensity of $x_{s j}$, it has to hire $\Gamma$ units of labor; in particular, $\Gamma_{s j t}=\frac{1}{\phi} \frac{x_{s j t}^{2}}{2}$.

\section{-Firms' Optimal Behavior}

I solve firms' optimal strategies by backward induction. Recall that new firms are heterogeneous in their initial productivity level, but they innovate to get a frontier technology. After learning the result of the innovation process, they decide whether to produce in the second period. Accordingly, I first compute the profits that they would obtain if they produce in $t+1$ and then compute their optimal innovation efforts in $t$.

Firms maximize profits by choosing their optimal quantities, given the outcome of the innovation technology and taking as given the wage and the interest rate. In particular,

$$
\operatorname{Max}_{y_{s j t+1}}\left(p_{s j t+1}-c_{s j t+1}\right) y_{s j t+1}
$$


st equation (38),

where $c_{s j t+1}$ represents the marginal cost of firm $s .{ }^{37}$ The first order condition implies the following optimal price:

$$
p_{s j t+1}=\frac{\varepsilon_{s j t+1}}{\varepsilon_{s j t+1}-1} c_{s j t+1},
$$

where $\varepsilon_{s j t+1}>1$ and represents the endogenous demand elasticity, given by

$$
\varepsilon_{s j t+1}=\left(\frac{1}{\theta} \omega_{s j t+1}+\frac{1}{\gamma}\left[1-\omega_{s j t+1}\right]\right)^{-1}
$$

where $\omega_{s j t+1}=\frac{p_{s j t+1} y_{s j t+1}}{p_{j t+1} y_{j t+1}}$ represents the market share of firm $s$ in $t+1$.

In the first period, firms choose their optimal innovation efforts $x_{s j t}$ to maximize their expected profits net of innovation costs. In particular,

$$
\operatorname{Max}_{x_{s j t}} x_{s j t} \Pi_{s j t+1}^{p o s t}+\left(1-x_{F j t}-x_{H j t}\right) \Pi_{s j t+1}^{p r e}-R_{t+1}^{s^{\prime}}\left[w_{t} \frac{1}{\phi} \frac{x_{s j t}^{2}}{2}\right]
$$

where $\Pi_{s j t+1}^{\text {post }}$ denotes the end-of-period profits if firm $s$ succeeds in innovating and climbing one step ahead in the quality ladder, and $\Pi_{s j t+1}^{p r e}$ are the profits if innovation is unsuccessful and the firm retains its initial productivity level. Therefore, home and foreign firms' optimal innovation efforts are

$$
x_{H j t}=\phi \frac{\left[\Pi_{H j t+1}^{p o s t}-\Pi_{H j t+1}^{p r e}\right]}{w_{t} R_{t+1}^{L}} \quad \text { and } \quad x_{F j t}=\phi \frac{\left[\Pi_{F j t+1}^{p o s t}-\Pi_{F j t+1}^{p r e}\right]}{w_{t} R_{t+1}^{*}} .
$$

Equation (40) shows that firms' innovation efforts depend on the incremental benefit from innovating (i.e. the difference between their pre- and post- innovation profits) relative to their innovation costs.

\section{-Numerical Exploration}

To see whether the pro-competitive forces implied by the Bertrand setting are also present under Cournot competition, I conduct a numerical exploration. This exercise does not aim toward quantifying the model, but rather to check whether the direction of the results is the same as in the paper. More precisely, I want to check whether the decrease in capital controls leads home firms to invest more in technology and whether the deeper competition encourages foreign firms to innovate more as well.

To study how firms' innovation incentives change when passing from an economy with capital controls to a fully liberalized economy, I first need to set an initial level of capital controls. In the model, this is represented by $\tilde{\tau}$, which denotes the wedge between the domestic and the foreign

${ }^{37}$ In particular, $c_{s j t+1}=\left(\frac{R_{t+1}^{s^{\prime}}}{\alpha}\right)^{\alpha}\left(\frac{w_{t+1}}{1-\alpha}\right)^{1-\alpha} \frac{1}{q_{s j t+1}}$, where $R^{s^{\prime}}$ would be the domestic lending rate $R^{L}$ for home firms and $R^{*}$ the international rate for foreign firms. 
interest rates. I set its initial level to $3 \%$, which was the interest rate differential between domestic and foreign firms prior to the reform (Table 1), and I let this parameter go to 0 as we move from the regulated to the liberalized economy. I let the international interest rate $R^{*}$ be $5.15 \%$, which was the level of a U.S. one-year T-bill in 2000. To better visualize the results, I consider a small wedge in the level of financial development in the country, and let $\mu$ be $0.1 \%$ and keep it constant throughout the exercise. I set $\alpha=1 / 3$. For simplicity, I assume that home and foreign firms have equal initial productivity, which I normalize to one. Following the literature in innovation (Acemoglu, Aghion, and Zilibotti 2006; Acemoglu and Akcigit 2011; among others), I set the technology parameters to $\lambda=1.2$ and $\phi=0.3$, which are the values used in Appendix B.4 and which match the aggregate productivity growth in Hungary prior to the reform (5.8\% per year). Results remain unaffected if these parameters change, for example, to $\lambda=1.05, \lambda=1.35, \phi=1$, or $\phi=5$. As in Devereux and Lee (2001), Atkeson and Burstein (2008) or Edmond, Midrigan, and Xu (2015), I choose the parameters of the within-variety and across-variety elasticities of substitution such that $\gamma>\theta$, i.e. the within-variety effects dominate the across-variety effects, and the firm's demand elasticity is lower the greater is its share of the variety output. As in Atkeson and Burstein (2008), I choose $\theta$ close to one $(\theta=1.01)$ to keep the expenditure of the composite good in each variety roughly stable. It is difficult to choose a parameter for $\gamma$, the within-variety elasticity of substitution between home and foreign firms' products. I follow Atkeson and Burstein (2008) and choose a benchmark $\gamma=10$, which implies a high elasticity of substitution between these goods. I next check the sensitivity of the analysis for $\gamma=5$ and $\gamma=20$. Finally, I consider a value for $\beta=0.5$.

Figure B.6.1 displays the results. The horizontal axis represents the level of capital controls $(\tilde{\tau})$, which goes from -0.03 under capital controls to 0 in the fully liberalized economy. It shows that a reduction in capital controls fosters all firms' innovation efforts. As in the Bertrand setting, the innovation efforts of home firms increase relatively more than foreign firms. To provide further evidence about the two forces driving the results, I also plot the evolution of home firms' leverage and foreign firms' markups. As expected, the reduction in financing terms leads home firms to increase their leverage and competitive pressure. This deeper competition raises foreign firms' endogenous demand elasticity and reduces their markups accordingly.

Figure B.6.2 plots the sensitivity analysis for $\gamma=5$ and $\gamma=20$. When $\gamma=5$ and the elasticity of substitution between home and foreign firms' products is low, asymmetric access to international capital markets still has a large impact on firms' innovation efforts. However, when $\gamma=20$ and competition between home and foreign firms' products is very intense, capital controls create a small distortion in firms' innovation intensities. The intuition for this result is that when the degree of product substitutability is very high, firms' profits and innovation efforts are low and, hence, the distortion caused by the asymmetric access to capital markets is low. In this way, capital market distortions affect firms' innovation efforts when firms enjoy some degree of market power over their products. 


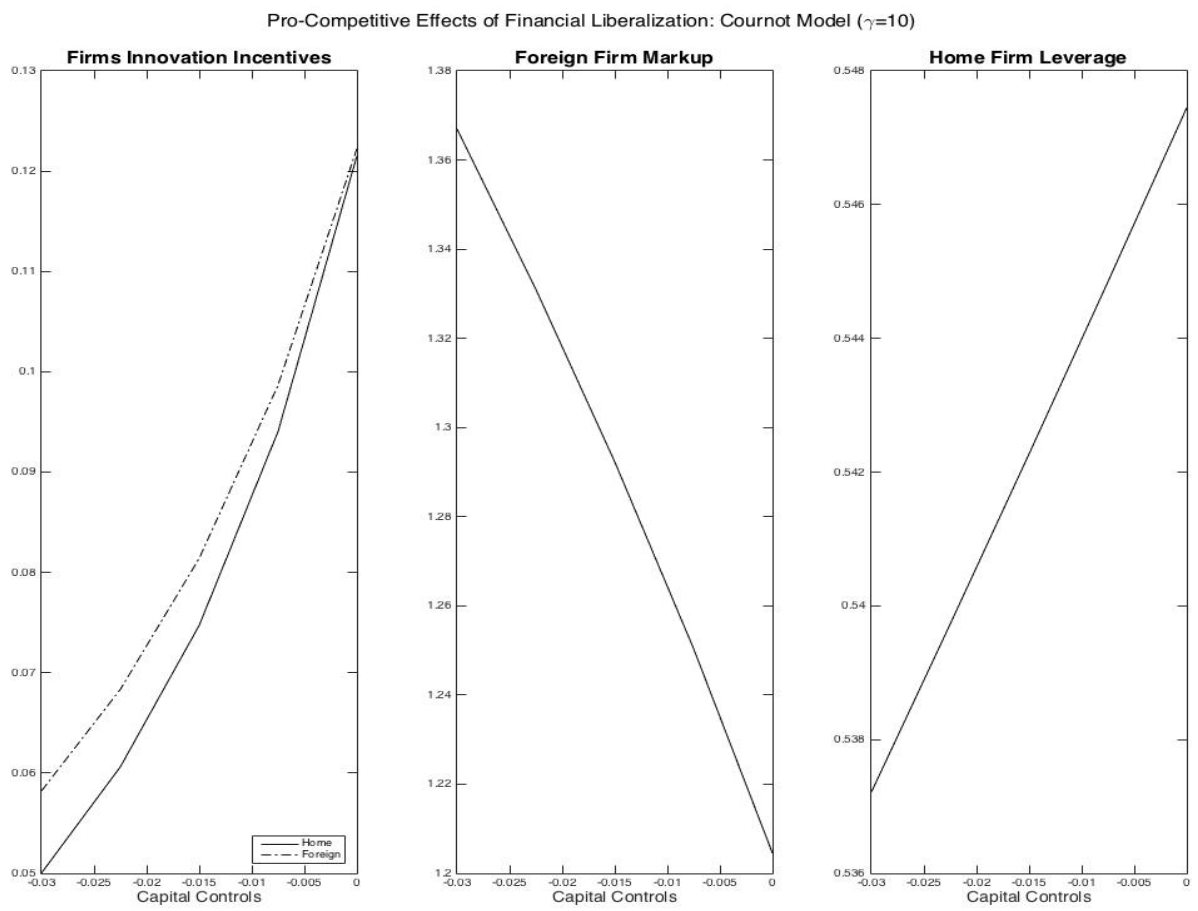

Figure B.6.1: Pro-Competitive Effects of Financial Liberalization under Cournot Competition 

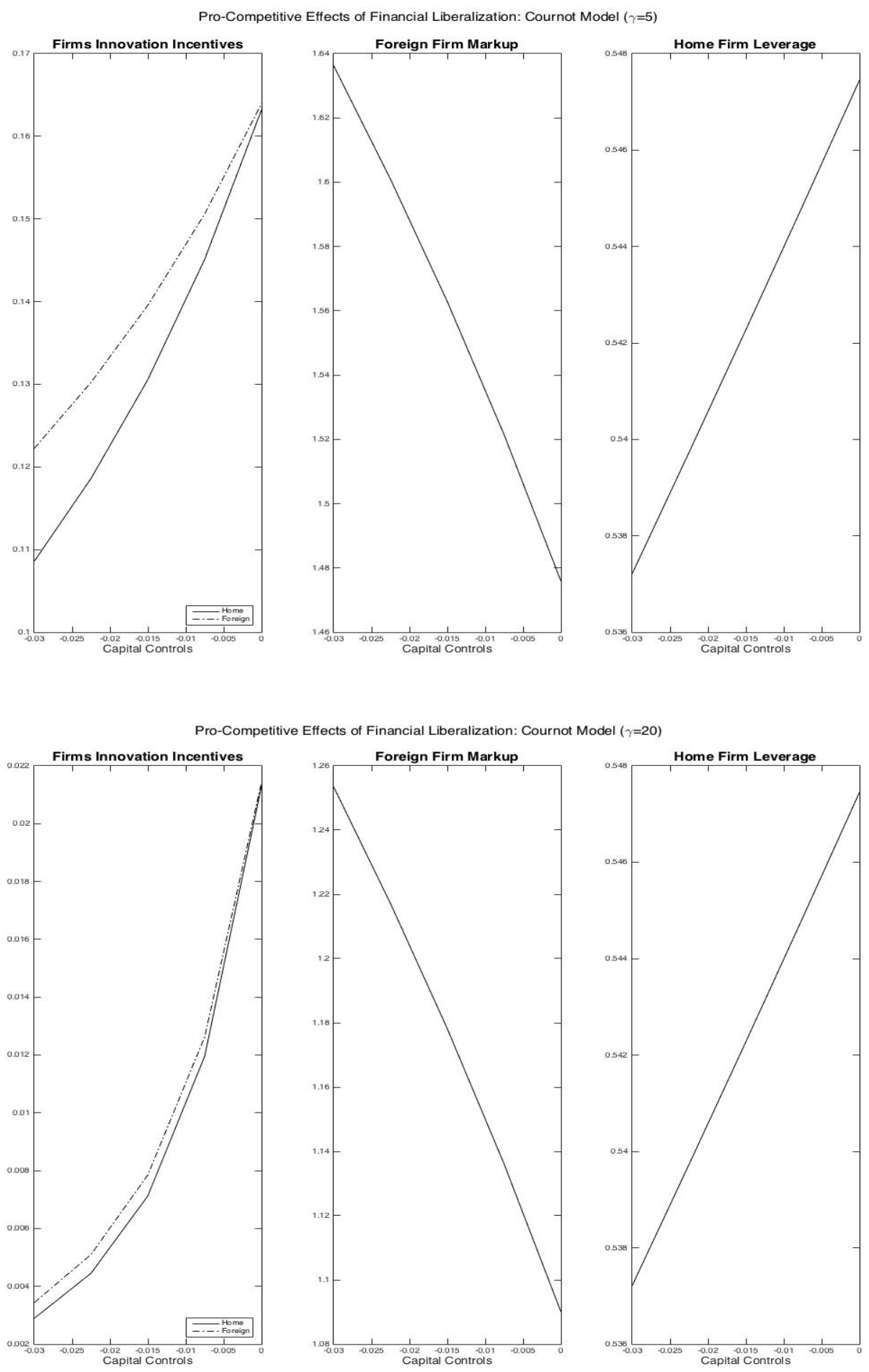

Figure B.6.2: Pro-Competitive Effects of Financial Liberalization under Cournot Competition (Sensitivity Analysis) 


\section{B.7. Firms' Innovation Costs}

In the model, I have assumed that more productive firms enjoy lower innovation costs. In particular, I have let the innovation costs of foreign firms be easier when their technological advantage is greater. In this section, I remove this assumption and show that the model's predictions remain true when home and foreign firms have equal innovation costs. Let firms' innovation costs be determined by

$$
\Gamma\left(x_{F j t}\right)=\frac{1}{\phi} \frac{x_{F j t}^{2}}{2} \text { and } \Gamma\left(x_{H j t}\right)=\frac{1}{\phi} \frac{x_{H j t}^{2}}{2} .
$$

Home and foreign firms' optimal innovation intensities are

$$
x_{F \Delta t}=\frac{\phi}{\tau_{t+1} \lambda^{\Delta}} \frac{\left(1-\lambda^{-1}\right)}{w_{t}} \frac{Y_{t+1}}{R_{t+1}^{*}} \quad \text { and } \quad x_{H t}=\frac{\phi}{\tau_{t+1}^{1 / \alpha}}\left(1-\tau_{t+1} \lambda^{-1}\right) \frac{Y_{t+1}}{R_{t+1}^{*}},
$$

where foreign firms' innovation efforts now depend on the technology gap between the foreign firms and their local competitors. Notice that the greater is the initial technology gap, the lower are foreign firms' innovation efforts.

Proposition 1: Innovation intensities. A reduction in the asymmetric access to international capital markets $(\tau)$ encourages all firms to increase their innovation intensities. Notably, the innovation efforts of home firms increase relatively more.

From equation (41), it is straightforward to see that $\frac{\partial x_{F \Delta t}}{\partial \tau_{t+1}}<0$ and $\frac{\partial x_{H t}}{\partial \tau_{t+1}}<0$. In addition, $\left|\frac{\partial x_{F \Delta t}}{\partial \tau_{t+1}}\right|<\left|\frac{\partial x_{H t}}{\partial \tau_{t+1}}\right|$. Note that the greater is the technology gap between foreign and home firms, the lower is foreign firms' increase in innovation.

Proposition 2: Leverage. A reduction in $\tau$ increases home firms' leverage.

That is, $\frac{\partial(d / y)_{H \Delta t+1}^{e}}{\partial \tau_{t+1}}<0$, where $(d / y)_{H \Delta t+1}^{e}$.

Proposition 3: Markups. A decrease in $\tau$ leads to reductions in foreign firms' markups.

The proof is similar to that in the main text. Under the law of large numbers, a continuum of varieties ensures that a foreign firm's markup will be equal to its expected value. More precisely,

$$
\xi_{F \Delta t+1}^{e}=\tau_{t+1} \lambda^{\Delta+1} x_{F \Delta t}+\tau_{t+1} \lambda^{\Delta}\left(1-x_{F \Delta t}+x_{H t}\right),
$$

and $\frac{\partial \xi_{F \Delta t+1}^{e}}{\partial \tau_{t+1}}>0$

Proposition 4: Productivity gap. Reductions in $\tau$ decrease the productivity gap between home and 
foreign firms. In particular, this drop is greater in sectors where foreign firms were technologically far ahead of their local competitors.

From Proposition 1, as home firms invest more in technology, the technology gap between the home firms and their foreign competitors narrows, i.e. $\frac{\partial \Delta_{t+1}^{e}}{\partial \tau_{t+1}}>0$. Furthermore, this decrease is larger, the greater is the initial gap between the home firms and their foreign rivals $\frac{\partial \Delta_{t+1}^{e}}{\partial \tau_{t+1} \partial \Delta}>0$.

Proposition 5: Aggregate productivity growth. A decrease in the asymmetric access to international borrowing $(\tau)$ increases aggregate productivity growth.

Aggregate productivity growth is given by

$$
g_{Q t+1}=\log (\lambda) \sum_{i=1}^{\infty} \mu_{i t+1}\left(x_{H t}+x_{F \Delta t}\right)=\log (\lambda)\left(\mu_{1 t+1} x_{H t}+\sum_{i=1}^{\infty} \mu_{i t+1} x_{F \Delta t}\right) .
$$

Since foreign firms' innovation efforts now depend on the initial technology gap between the foreign firms and their local competitors (equation (41)), aggregate productivity growth depends on the distribution of technology gaps in the economy, i.e. $\sum_{i=1}^{\infty} \mu_{i t+1}$. It can be shown that $\frac{\partial g_{Q t+1}}{\partial \tau_{t+1}}<0$, i.e. the decrease in the distortion in the access to international capital markets raises aggregate productivity growth. What is new here is that the increase in aggregate productivity growth originates from two sources. First, similar to the main text, as both home and foreign firms invest more in technology (Proposition 1), productivity increases. Second, the decrease in the dispersion of the distribution of productivity gaps raises aggregate productivity growth. More precisely, as home firms undertake greater innovation efforts than their foreign competitors, the number of sectors where foreign firms are technologically far ahead of the local firms decreases, i.e. $\mu_{1 t+1}$ increases. Since the innovation efforts of foreign firms in technologically dispersed sectors are lower (equations (41)), the smaller number of these sectors in the economy raises aggregate productivity growth. This can be directly seen from the distribution of productivity gaps:

$$
\dot{\mu}= \begin{cases}-\mu_{1 t+1} x_{F 1 t}+x_{H t}\left(1-\mu_{1 t+1}\right) & \Delta=1, \\ \left(x_{F \Delta t}+x_{H t}\right) \mu_{\Delta t+1}+x_{F \Delta t} \mu_{\Delta-1, t+1} & \Delta \geq 2\end{cases}
$$

For the distribution to be stationary, $\dot{\mu}=0$ and therefore $\mu_{1}=\frac{x_{H}}{x_{F 1}+x_{H}}$. As $\frac{\partial \mu_{1}}{\partial \tau}<0$, a decrease in the distortion in the access to capital markets raises the fraction of $\mu_{1}$ sectors and decreases the fraction of sectors where foreign firms are technologically far ahead of their local competitors. 


\section{Appendix C Financial System's Supervisory Framework}

In Hungary, the deregulation of the foreign exchange market implied the amendment of other complementary laws in order to guarantee a stable and well-functioning financial system. In the new open economy regime, some earlier regulations became obsolete and needed to be adjusted to the new forms of capital flows.

More precisely, one of the changes introduced by FX Act XCIII was the liberalization of crossborder securities in foreign currency (as derivatives). The use of these securities needed some regulation, as these are key tools in the risk management of banks and, hence, in the stability of the financial system. The amendment of the Capital Market Act (Act CXX of 2001) filled this gap and regulated the scope of these instruments for financial institutions. Additionally, the deregulation of the FX market required the regulation of clearing houses that trade foreign currency, which thereafter were allowed to enter the market. This regulation was also included in the amendment to the Capital Market Act (see Capital Market Act 2001). Another challenge posed by the financial liberalization was the adjustment of the supervisory framework of financial institutions, as thereafter they could trade foreign currency instruments and, hence, be exposed to currency risk in various ways. Financial institutions' exposure was regulated in the amendments to the Capital Market Act and Credit Institution Act (CXII of 1996), which introduced consolidated reporting and limited the overall currency exposure of financial groups (IMF 2002). The use of financial derivatives in the insurance sector also requiered the amendment of the insurance act, which "address[ed] the need for internal controls of the use of derivatives" of insurance companies (IMF 2002, p.36). 